\title{
Impact of Manaus City on the Amazon Green Ocean atmosphere: ozone production, precursor sensitivity and aerosol load
}

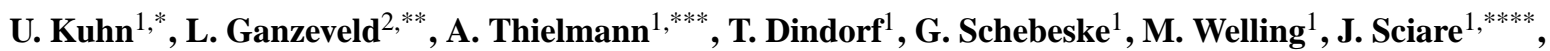 \\ G. Roberts ${ }^{1, * * * * *}$, F. X. Meixner ${ }^{1,8}$, J. Kesselmeier ${ }^{1}$, J. Lelieveld ${ }^{2}$, O. Kolle ${ }^{3}$, P. Ciccioli ${ }^{4}$, J. Lloyd ${ }^{5}$, \\ J. Trentmann ${ }^{6, * * * * * *}$, P. Artaxo ${ }^{7}$, and M. O. Andreae ${ }^{1}$ \\ ${ }^{1}$ Max Planck Institute for Chemistry, Biogeochemistry Dept., Mainz, Germany \\ ${ }^{2}$ Max Planck Institute for Chemistry, Atmospheric Chemistry Dept., Mainz, Germany \\ ${ }^{3}$ Max Planck Institute for Biogeochemistry, Jena, Germany \\ ${ }^{4}$ Istituto di Metodologie Chimiche, Area delle Ricerca di Roma, Monterot, Scalo, Italy \\ ${ }^{5}$ Earth and Biosphere Institute, School of Geography, University of Leeds, UK \\ ${ }^{6}$ Institute for Atmospheric Physics, Johannes Gutenberg University Mainz, Germany \\ ${ }^{7}$ Instituto de Física da Universidade de São Paulo, São Paulo, Brazil \\ ${ }^{8}$ Physics Dept., University of Zimbabwe, Harare, Zimbabwe \\ *now at: Agroscope Reckenholz-Tänikon Research Station ART, Zurich, Switzerland \\ ** now at: Department of Environmental Sciences, Wageningen University and Research Centre, Wageningen, \\ The Netherlands \\ ${ }^{* * *}$ now at: Siemens AG, Environmental Systems and Services, Erlangen, Germany \\ **** now at: Laboratoire des Sciences du Climat et de l'Environnement, Gif-sur-Yvette, France \\ ****** now at: Scripps Institution of Oceanography, Center for Atmospheric Sciences and Physical Oceanography, \\ La Jolla, CA, USA \\ ******** now at: German Weather Service (DWD), Offenbach, Germany
}

Received: 21 January 2010 - Published in Atmos. Chem. Phys. Discuss.: 25 May 2010

Revised: 30 August 2010 - Accepted: 6 September 2010 - Published: 1 October 2010

\begin{abstract}
As a contribution to the Large-Scale BiosphereAtmosphere Experiment in Amazonia - Cooperative LBA Airborne Regional Experiment (LBA-CLAIRE-2001) field campaign in the heart of the Amazon Basin, we analyzed the temporal and spatial dynamics of the urban plume of Manaus City during the wet-to-dry season transition period in July 2001. During the flights, we performed vertical stacks of crosswind transects in the urban outflow downwind of Manaus City, measuring a comprehensive set of trace constituents including $\mathrm{O}_{3}, \mathrm{NO}, \mathrm{NO}_{2}, \mathrm{CO}, \mathrm{VOC}, \mathrm{CO}_{2}$, and $\mathrm{H}_{2} \mathrm{O}$. Aerosol loads were characterized by concentrations of total aerosol number $(\mathrm{CN})$ and cloud condensation nuclei $(\mathrm{CCN})$, and by light scattering properties. Measurements over pristine rainforest areas during the campaign showed low lev-
\end{abstract}

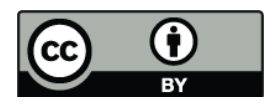

Correspondence to: U. Kuhn (uwe.kuhn@art.admin.ch) els of pollution from biomass burning or industrial emissions, representative of wet season background conditions. The urban plume of Manaus City was found to be joined by plumes from power plants south of the city, all showing evidence of very strong photochemical ozone formation. One episode is discussed in detail, where a threefold increase in ozone mixing ratios within the atmospheric boundary layer occurred within a $100 \mathrm{~km}$ travel distance downwind of Manaus. Observation-based estimates of the ozone production rates in the plume reached $15 \mathrm{ppbh}^{-1}$.

Within the plume core, aerosol concentrations were strongly enhanced, with $\Delta \mathrm{CN} / \Delta \mathrm{CO}$ ratios about one order of magnitude higher than observed in Amazon biomass burning plumes. $\Delta \mathrm{CN} / \Delta \mathrm{CO}$ ratios tended to decrease with increasing transport time, indicative of a significant reduction in particle number by coagulation, and without substantial new particle nucleation occurring within the time/space observed. While in the background atmosphere a large

Published by Copernicus Publications on behalf of the European Geosciences Union. 
fraction of the total particle number served as $\mathrm{CCN}$ (about $60-80 \%$ at $0.6 \%$ supersaturation), the $\mathrm{CCN} / \mathrm{CN}$ ratios within the plume indicated that only a small fraction $(16 \pm 12 \%)$ of the plume particles were CCN. The fresh plume aerosols showed relatively weak light scattering efficiency. The COnormalized CCN concentrations and light scattering coefficients increased with plume age in most cases, suggesting particle growth by condensation of soluble organic or inorganic species.

We used a Single Column Chemistry and Transport Model (SCM) to infer the urban pollution emission fluxes of Manaus City, implying observed mixing ratios of $\mathrm{CO}, \mathrm{NO}_{\mathrm{x}}$ and VOC. The model can reproduce the temporal/spatial distribution of ozone enhancements in the Manaus plume, both with and without accounting for the distinct (high $\mathrm{NO}_{\mathrm{x}}$ ) contribution by the power plants; this way examining the sensitivity of ozone production to changes in the emission rates of $\mathrm{NO}_{\mathrm{x}}$. The VOC reactivity in the Manaus region was dominated by a high burden of biogenic isoprene from the background rainforest atmosphere, and therefore $\mathrm{NO}_{\mathrm{x}}$ control is assumed to be the most effective ozone abatement strategy. Both observations and models show that the agglomeration of $\mathrm{NO}_{\mathrm{x}}$ emission sources, like power plants, in a well-arranged area can decrease the ozone production efficiency in the near field of the urban populated cores. But on the other hand remote areas downwind of the city then bear the brunt, being exposed to increased ozone production and $\mathrm{N}$-deposition. The simulated maximum stomatal ozone uptake fluxes were $4 \mathrm{nmol} \mathrm{m}^{-2} \mathrm{~s}^{-1}$ close to Manaus, and decreased only to about $2 \mathrm{nmol} \mathrm{m}^{-2} \mathrm{~s}^{-1}$ within a travel distance $>1500 \mathrm{~km}$ downwind from Manaus, clearly exceeding the critical threshold level for broadleaf trees. Likewise, the simulated $\mathrm{N}$ deposition close to Manaus was $\sim 70 \mathrm{~kg} \mathrm{~N} \mathrm{ha}^{-1} \mathrm{a}^{-1}$ decreasing only to about $30 \mathrm{~kg} \mathrm{~N} \mathrm{ha}^{-1} \mathrm{a}^{-1}$ after three days of simulation.

\section{Introduction}

Tropical regions play a central role in the budgets of trace gases and aerosols of the Earth's atmosphere, as well as in the absorption of solar energy and its transfer into the climate system. In particular, the vast regions of highly active terrestrial ecosystems in the wet tropics have a pronounced influence on the global carbon cycle and the atmospheric burdens of other greenhouse gases. They are also large sources of reactive trace gases, which figure prominently in the atmospheric oxidation cycle (Crutzen, 1987). The tropical region of South America, with the Amazon Basin at its heart, contains the world's largest area of humid tropical forest and savanna, much of which is undergoing profound changes due to human activities (Betts et al., 2008). This is underscored by estimates that tropical human populations are among the fastest growing on earth (Oke, 1986). Many of the urban ar- eas in the tropics are expanding rapidly, and well-governed densely populated settlements can reduce the need for land conversion and provide proximity to infrastructure and services (Molina and Molina, 2004). However, increasing industrialisation and motorisation have also resulted in higher demand for energy, greater use of fossil fuels, and severe increases in the emissions of pollutants into the atmosphere, with resulting adverse impacts on air quality. Amongst the most important anthropogenic pollutants are nitrogen oxides $\left(\mathrm{NO}_{\mathrm{x}}=\right.$ sum of nitric oxide $[\mathrm{NO}]$ and nitrogen dioxide $\left[\mathrm{NO}_{2}\right]$ ), volatile organic compounds (VOCs), carbon monoxide (CO) and aerosols, all of which drive the formation of photochemical smog and control the photochemical production of tropospheric ozone $\left(\mathrm{O}_{3}\right)$ and the hydroxyl radical $(\mathrm{OH})$. These oxidants play a key role in determining the oxidizing power of the global atmosphere, and thus the capacity of the atmosphere to cleanse itself; while on the other hand their build-up by photochemical air pollution may threaten both human and ecosystem health on regional and continental scales. The major part of the oxidation of long-lived gases by $\mathrm{OH}$ takes place in the tropics, where high UV and humidity promote the formation of $\mathrm{OH}$ from photolysis of $\mathrm{O}_{3}$ (Logan et al., 1981; Thompson, 1992; Lelieveld et al., 2008).

By combining high background VOC mixing ratios in a sunny, hot, and humid environment the tropical rainforest environment is predestined to lead to strong ozone formation when exposed to anthropogenic $\mathrm{NO}_{\mathrm{x}}$. A key issue in developing an effective emission-based $\mathrm{O}_{3}$ control strategy is to understand the non-linear relationship between $\mathrm{O}_{3}$ formation and its precursors in the urban outflow, and to evaluate the sensitivity of $\mathrm{O}_{3}$ formation to any emission reduction of its anthropogenic precursors. Recently, numerical models have been applied to study photochemical oxidants in Brazilian areas (Freitas et al., 2005; Dallarosa et al., 2007), but data are available only very sparsely for urban conditions within the "Great Chemical Reactor" of the Amazon basin (Andreae, 2001).

The importance of biogenic background VOC for urban photochemical smog has already been highlighted by Chameides et al. (1988) for the Atlanta case. Since cities like Manaus lie within the largest terrestrial sources of biogenic VOC (Guenther et al., 1995), there are global scale motivations for characterizing their local atmospheric chemistry. While in the absence of anthropogenic $\mathrm{NO}_{\mathrm{x}}$ emissions, biogenic VOC are considered to contribute little to ozone formation (or may even lead to a reduction in ambient ozone mixing ratios), it is common knowledge that the photooxidation of isoprene in the presence of sufficient $\mathrm{NO}_{\mathrm{x}}$ results in formation of ozone and can give rise to strongly elevated ozone levels in both urban and rural environments in summer (Trainer et al., 1987; Chameides et al., 1992; Biesenthal et al., 1997; Starn et al., 1998; Roberts et al., 1998; Wiedinmyer et al., 2001). The polluted outflow plume of Manaus City enters the otherwise unpolluted atmosphere of the tropical rainforest (dubbed "green ocean air" by Williams et al., 
2002), where $\mathrm{NO}_{\mathrm{x}}$ levels are near the crossover point from net loss of $\mathrm{O}_{3}$ to net production. Anthropogenic injection of $\mathrm{NO}_{\mathrm{x}}$ into the remote background air is assumed to have a strong impact on the $\mathrm{O}_{3}$ abundance in the near field (urban area) as well as in the far field (downwind remote areas). Moreover, recent results show that high uncertainties in the mechanisms and products of important reactions of oxidants in the tropical atmosphere still exist (Kuhn et al., 2007; Lelieveld et al., 2008).

Urban photochemical smog episodes are also accompanied by high aerosol loads, with potential negative impacts on human health (Pope and Dockery, 2006). Traffic and power plants are main sources of urban particulate matter by directly emitting particles and gaseous precursors that further react and form condensable material (EPA AP-42; http://www.epa.gov/ttnchie1/ap42/). Presumably high radical levels associated with photochemical smog in urban plumes favour the formation of secondary aerosols, both inorganic and organic, which on the other hand modify the oxidation efficiency of the atmosphere by way of heterogeneous reactions. Because of the large biogenic background sources of VOC, which act as key precursors for SOA formation, a potentially important production of secondary organic aerosol (SOA) is anticipated for tropical urban plumes. In addition to the recognized role of biogenic monoterpenes in SOA formation (e.g., Kavouras et al., 1999), recent studies also suggest the importance of isoprene (e.g., Claeys et al., 2004; Kroll et al., 2006). Photochemistry and aerosol formation are coupled in terms of (i) the influence of aerosols on the radiation properties (scattering/absorption of sunlight), and (ii) the reaction of radicals with the aerosol surface or within water droplets. Specifically the temporal and spatial distribution of these pollutants with respective changes in their chemical, physical and optical properties are very complex and currently not well characterized.

The indirect radiative effects of aerosols through their role in cloud formation are complex and contribute the largest uncertainty in radiative forcing calculations (IPCC, 2007; Rosenfeld et al., 2008). The chemical and physical characteristics of smoke and biogenic aerosols over Amazonia and their effects on cloud microphysics have been investigated in previous campaigns (Roberts et al., 2001, 2003; Andreae, 2009; Andreae et al., 2004; Freud et al., 2008; Martin et al., 2010a; Gunthe et al., 2009; Rissler et al., 2004; Fuzzi et al., 2007; Vestin et al., 2007; Artaxo et al., 2002). These studies have shown that under unpolluted conditions aerosol and cloud condensation nuclei $(\mathrm{CCN})$ concentrations over the Amazon are very low (of the order of $100-400 \mathrm{~cm}^{-3}$ ), but can be increased by as much as two orders of magnitude during the biomass burning season. Under the low-aerosol conditions that prevail over pristine Amazon forest, even modest additions of $\mathrm{CCN}$ can lead to pronounced changes in cloud properties (Andreae et al., 2004; Freud et al., 2008). Urban emissions therefore have the potential to cause significant modifications in cloud properties in the downwind region. So far, the CCN properties of urban aerosols in South America have not yet been investigated. The existence of an isolated plume in an otherwise very pristine environment downwind of Manaus offers the possibility to investigate the evolution of the aerosols over several hours following emission.

While anthropogenic emissions are concentrated in urban areas, the ozone deposition rates as well as the emission of biogenic VOC can be reasonably assumed to be lower due to the reduced amount of vegetation. City islands also affect vertical transport and mixing depending e.g., on soil moisture, roughness, anthropogenic heat production, and hence the surface energy balance, which by itself may cause substantial changes in the concentrations of atmospheric trace constituents. The effect of a strong convective system passing through the urban plume of Manaus was studied based on airborne measurements by Pickering et al. (1992), focussing on an isolated event at a distance of $50 \mathrm{~km}$ downwind of Manaus City. It has been shown that convective transport away from the surface enables precursor VOCs and $\mathrm{NO}_{\mathrm{x}}$ to achieve their full ozone generating potential, and that dilution from the boundary layer into a free tropospheric column may significantly increase the net ozone yields (Liu et al., 1987; Lin et al., 1988; Pickering et al., 1990; Lelieveld and Crutzen, 1994). Local ground-based observations may thus be inadequate to understand the net effects of the urban perturbation, e.g., since ozone production at the surface accounts only for a small fraction of the total ozone column. Conditions at a surface site will only be representative for a large part of the ozone production if the site is not affected by local emissions and at times when strong vertical mixing is established (Spirig et al., 2002).

During the LBA-CLAIRE-2001 campaign, we used airborne measurements downwind of Manaus City to investigate the temporal and spatial dynamics of the urban plume. The LBA-CLAIRE-2001 campaign forms part of a series of integrated airborne and ground-based campaigns, the Cooperative LBA Airborne Regional Experiment (LBA-CLAIRE), which in turn is part of the Large-Scale Biosphere-Atmosphere Experiment in Amazonia (LBA). Specific goals of the campaign included quantifying the spatial distribution and transport processes of the urban plume, and analyzing pollutant mixing ratios and chemical transformation within the plume. The results are used to examine the impacts of urbanization on the net exchange and atmospheric chemistry of important gases and aerosols, and to provide scientific insights in the potential consequences and efficiencies of emission abatement strategies.

\section{Experimental}

\subsection{Instrumentation}

For LBA-CLAIRE-2001, the twin-engine turboprop Embraer Bandeirante EMB-110B1, operated by the Brazilian 
National Institute for Space Research (INPE, Instituto Nacional de Pesquisas Espaciais) was equipped with a suite of instruments for the measurement of gaseous compounds and aerosols. A variety of inlet tubes were assembled with their inlet ends forward of the engines.

Nitric oxide (NO) was measured by chemiluminescence using a CLD 780 TR (ECO PHYSICS AG, Switzerland). A precision of $5 \%$ was computed for a $1 \mathrm{~s}$ integration time from the standard deviation during the NO calibration. The performance of the instrument is governed by its background signal, which was monitored frequently during each flight. The detection limit of the instrument was $30 \mathrm{ppt}$, determined from the standard deviation during the zero calibrations. Nitrogen dioxide $\left(\mathrm{NO}_{2}\right)$ is detected as NO by the same detector, after conversion by photolysis (ECO PHYSICS PLC 760) upstream of the NO detector. Photolysis is by far more selective than conventional catalytic conversion of $\mathrm{NO}_{2}$ (McClenny et al., 2002). A drawback of using photolysis is the need for calibration, as the conversion efficiency is not unity. This efficiency was determined as 0.41 . The precision, determined in the same way as for $\mathrm{NO}$, was $150 \mathrm{ppt}$.

Ozone $\left(\mathrm{O}_{3}\right)$ was measured with a resolution of $10 \mathrm{~s}$ with a UV-absorption instrument (Model 49C, Thermo Environment Instruments Inc., USA). The precision was $1 \mathrm{ppb}$, internal pressure and temperature corrections were verified by tests in the laboratory. Carbon monoxide (CO) was measured with a $1 \mathrm{~s}$ resolution by UV resonance fluorescence, using a Fast-CO-Monitor (Model AL 5002, Aerolaser GmbH, Germany). Prior to measurement, the air was dried using a Nafion drier. In flight, zero and span calibrations were made to account for instrumental drift associated with varying pressure and temperature. The precision of the $1 \mathrm{~Hz}$ data was $1.5 \%$, and the accuracy was estimated to be better than $5 \%$ (Guyon et al., 2005). Carbon dioxide $\left(\mathrm{CO}_{2}\right)$ was measured with a resolution of $1 \mathrm{~Hz}$ using a LICOR (model LI 6251) infrared gas analyzer. The sampled air was dried with magnesium perchlorate prior to analysis. The precision after applying temperature and pressure corrections was estimated to be $\pm 0.4 \mathrm{ppm}$ (for details see Lloyd et al., 2001, 2007).

The aircraft was equipped with a GPS (Garmin), and the outside air pressure, temperature and relative humidity were measured using a Vaisala PTB101B pressure transducer, and a Vaisala HMP35D temperature-humidity-probe, mounted on the bottom of the airplane behind the gas inlet tubes (directly in the airstream).

VOC grab samples within the plume (5-7 min sampling interval) were collected on solid adsorbent cartridges using an automated sampler and subsequent off-line analysis in the lab (Kuhn et al., 2005). Sample collection start time and period for plume transects were selected according to the online readings of the $\mathrm{CO}$ instrument. Two different sampling/analysis systems were used simultaneously. GC/FID samples were collected on fused silica-lined stainless steel cartridges with 2-bed graphitic carbon adsorbents (130 mg Carbograph 1, followed by $130 \mathrm{mg}$ Carbograph 5;
Lara s.r.l., Rome, Italy) and analyzed using a thermal desorption gas chromatograph with a flame ionization detector as described in Kuhn et al. (2002, 2004a). Calibration was accomplished by use of different gaseous standards containing isoprene, several n-alkanes, methyl vinyl ketone (MVK), and methacrolein (MACR). The detection limit was estimated as the greater of the variability in the blank levels (at the $95 \%$ confidence level, i.e., 1.96 times the standard deviation of all blank values), or a chromatographic peak three times the standard deviation of the background noise in the base line of the chromatograph. Variability in the blank usually determined the detection limit, which was typically $30 \mathrm{ppt}$ for isoprene and $10 \mathrm{ppt}$ for monoterpenes. Overall uncertainties were $\pm 10 \%$ for isoprene at $1 \mathrm{ppb}$ and ranged from \pm 5 to $\pm 30 \%$ at $100 \mathrm{ppt}$ for monoterpenes, depending on the individual monoterpene peak resolution and blank variability. GC/MS samples were collected on glass cartridges with 3bed graphitic carbon adsorbents samples (118 mg Carbopack C, Supelco, Bellefonte, USA, followed by $60 \mathrm{mg}$ Carbograph 1 and $115 \mathrm{mg}$ Carbograph 5, Lara s.r.l., Rome, Italy). These were analyzed by thermal desorption gas chromatography with mass spectrometric analysis (GC-MS). The detection limits and precision were in the same range as for GC-FID analysis.

Total aerosol number concentrations $(\mathrm{CN})$ were measured at $1 \mathrm{~Hz}$ time resolution by a TSI 3010 condensation particle counter (CPC; TSI Incorporated, Minnesota, USA). The sampling flow of the CPC was controlled by a capillary tube, adjusted for pressure and temperature of the sampled air, and the number concentrations corrected using the calculated flow. The data were corrected for coincidence using the manufacturer's suggested equation. Guyon et al. (2005) showed in a subsequent campaign that, compared to the number size distribution of smoke particles measured simultaneously with a scanning mobility particle sizer (SMPS 3080, TSI Incorporated, Shoreview, Minnesota, USA), the number concentration of particles ranging $8-300 \mathrm{~nm}$ in diameter measured by the CPC comprised at least $95 \%$ of the total population. Overall uncertainties are estimated to be ca. 5\%, including the potential effect of inlet losses of particles in the size range $300-500 \mathrm{~nm}$ at higher altitudes. On some of the flights, particle concentrations $>10.000 \mathrm{~cm}^{-3}$ could not be stored due to signal saturation in the datalogger. Such concentrations typically occurred in the middle of the Manaus plume, so that for these flights only the data measured at the boundaries of the plume core could be used to retrieve $\mathrm{CN}$ numbers.

$\mathrm{CCN}$ concentrations at $0.6 \%$ supersaturation (SS), indicated as $\mathrm{CCN}_{0.6}$, were measured using a static thermalgradient chamber as described by Roberts et al. $(2001,2003)$ with a time resolution of $35 \mathrm{~s}$. The calibration procedure involved generating a quasi-monodispersed aerosol of a known concentration and composition, and counting the number of activated droplets. An error analysis from calibration measurements indicates that for typical aerosol spectra, the 
overall measurement error in number concentrations is approximately $\pm 20 \%$. Aerosol scattering coefficients at 450 , 440 , and $700 \mathrm{~nm}$ were obtained using a TSI 3563 nephelometer. Aerosols were sampled in the same fashion as for the $\mathrm{CPC}$ measurements, and the data were stored on the datalogger at a $1 \mathrm{~Hz}$ resolution (Chand et al., 2005). Particle number concentration and all other aerosol particle parameters have been normalized to a standard air pressure $(1000 \mathrm{hPa})$ and temperature $(273.15 \mathrm{~K})$.

\subsection{Measuring site and meteorological conditions}

At the time of the campaign in 2001, Manaus City was estimated to have about 1.2 million human inhabitants. The total energy consumption of $570 \mathrm{GW}$, mainly supplied by three thermoelectric power plants placed in a common facility in the Mauzinho district $\left(3.12^{\circ} \mathrm{S}, 59.93^{\circ} \mathrm{W}\right)$ and another plant in the Aparecida district $\left(3.13^{\circ} \mathrm{S}, 60.03^{\circ} \mathrm{W}\right)$, were all located at the southern edge of Manaus City (Manaus Energy Inc.; see Fig. 1). A total of 255000 vehicles were estimated to be being operated in Manaus at the time (F. Luizão, DETRAN, personal communication, 2006). Other major sources of emissions in Manaus are saw mills burning timber residues and small-scale residential burnings. On the peninsula between the Solimoes and Rio Negro rivers south of Manaus, there are a number of charcoal kilns and brick factories fuelled with charcoal and wood.

The LBA-CLAIRE-2001 campaign was carried out in the wet-to-dry season transition in July 2001, when the InterTropical Convergence Zone was located at ca. $6^{\circ} \mathrm{N}$. Average yearly rainfall in Manaus is $2200 \mathrm{~mm}$ with two marked seasons (November-May wet; June-October dry). Although highly variable, rainfall is present throughout the year. Rainforest ecosystem characteristics of the Manaus area are described in detail in Andreae et al. (2002) and Kuhn et al. (2007).

The air flow during the airborne measurements was dominated by easterly trade winds in the lowest $5 \mathrm{~km}$ of the atmosphere, which transported humid oceanic air masses from the Atlantic more than $1000 \mathrm{~km}$ over vast expanses of largely undisturbed rain forest of the Amazon Basin, before reaching the urban area of Manaus (Dias et al., 2002). During part of the campaign, the airmasses had travelled over biomass burning regions in the states of Maranhão, Goiás, Piauí, Ceará, and eastern parts of Pará (9 July, 16:00 UTC to 16 July, $\sim$ 14:00 UTC; determined using trajectories with $500 \mathrm{~m}$ level arrival height at Manaus). Fires were frequently detected within these states by satellite remote sensing (NOAA12 and NOAA14; see Fig. 1 in Rissler et al., 2004). The transport time from the biomass burning source region to our measurement region was $2.5-5$ days. The cleanest conditions were found during the period 16 July (after $\sim 16: 00$ UTC) to 19 July. The concentrations of $\mathrm{CO}$ and aerosols in the regional background atmosphere (i.e., outside the Manaus ur-

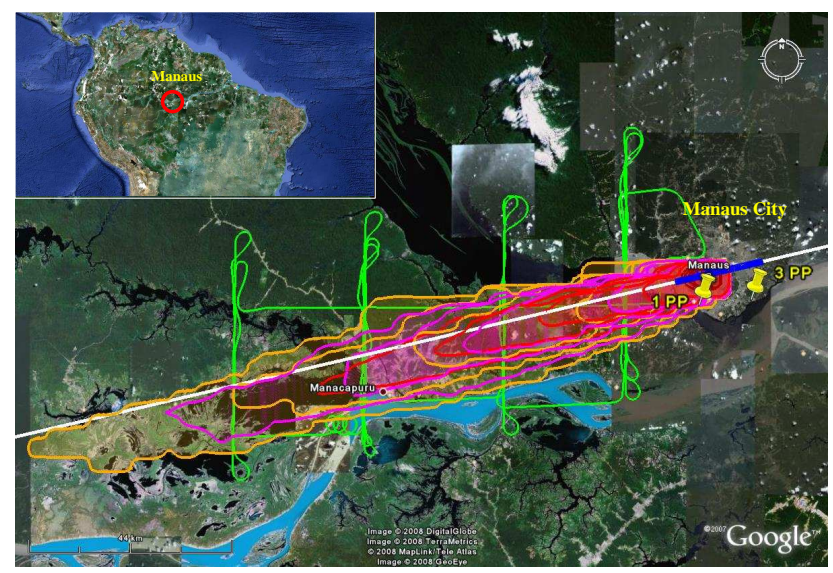

Fig. 1. Land cover image (GOOGLE EARTH) with an overlay of the flight pattern of Flight \#18 on 19 July 2001 at 10.00-14:00 LT (GPS data, green line), the path of the SCM model (white line, the blue colour indicates where surface characteristics in the SCM are changed to city conditions), and the output of a HYSPLIT dispersion model run indicated by the red/orange contour lines (based on meteorological REANALYSIS dataset for the time of the flight period, i.e., start time in Manaus City $\left(-3.08^{\circ},-60.01^{\circ}\right)$ was 10:00 LT, with $4 \mathrm{~h}$ total run time in the $0-1500 \mathrm{~m}$ level). The 2 yellow pins within Manaus City indicate the areas where power plants are located ( $3 \mathrm{PP}$ with $>560 \mathrm{MW}$ in the southeast, and $1 \mathrm{PP}$ with $>125 \mathrm{MW}$ in the southwest of the city). The overview map shows the location of Manaus within the Amazon rain forest (South America).

ban plume and occasional regional biomass smoke plumes) are summarized in Table 1.

Here we mainly focus on one particular flight carried out on midday of 19 July 2001 (at 10:00-14:00 LT; hereafter defined as Flight \#18), being that with the most comprehensive data set for the analysis of the Manaus plume available. Where appropriate, data from other flights are also presented. Weather conditions during Flight \#18 were mostly sunny, but with intermittent clouds. Wind conditions were characterized by relatively strong mean horizontal wind speed, with $3-5 \mathrm{~m} \mathrm{~s}^{-1}$ measured on a $52 \mathrm{~m}$ walk-up scaffolding tower (ca. $20 \mathrm{~m}$ above the forest canopy, K34, $2^{\circ} 35^{\prime} 33^{\prime \prime} \mathrm{S}$, $60^{\circ} 12^{\prime} 27^{\prime \prime} \mathrm{W}$ ), which was located on a medium-sized plateau about $60 \mathrm{~km}$ NNW of the city of Manaus. The mean wind speed within the entire CBL $(0-1500 \mathrm{~m}$ level) was derived from the HYSPLIT dispersion model constrained with reanalyzed meteorological data for this period, and was about $10 \mathrm{~m} \mathrm{~s}^{-1}$, which is characteristic for the storm-intensive periods of the wet season. Crutzen et al. (1985) computed dry season average velocities of $7 \mathrm{~m} \mathrm{~s}^{-1}$ at $850 \mathrm{hPa}$ and Andreae et al. (1988) presented similar results. At the surface tower site, wind direction was predominantly from the east, ranging between $90-104^{\circ}$ during the flight period.

The land cover map in Fig. 1 shows that the plume passed the Rio Negro river over an expanse of ca. $12 \mathrm{~km}$, before 
Table 1. Complete set of measurements of long-lived trace gases and aerosols in the regional background atmosphere (outside the Manaus urban plume and occasional regional biomass smoke plumes) during LBA-CLAIRE-2001. CN Balbina refers to CN concentrations measured simultaneously at the Balbina ground-based site. $\sigma_{\mathrm{sp}}(550 \mathrm{~nm})$ is the scattering coefficient at $550 \mathrm{~nm}$ wavelength. All concentrations and scattering coefficients have been normalized to standard conditions in dry air $(273.15 \mathrm{~K}, 1000 \mathrm{hPa})$.

\begin{tabular}{|c|c|c|c|c|c|c|c|c|c|c|c|c|}
\hline $\begin{array}{l}\text { Flight } \\
{[\#]}\end{array}$ & $\begin{array}{l}\text { Date } \\
\text { [dd.mm] }\end{array}$ & $\begin{array}{l}\text { Altitude } \\
\text { [m a.s.l.] }\end{array}$ & $\begin{array}{l}\text { Press } \\
{[\mathrm{hPa}]}\end{array}$ & $\begin{array}{r}\text { Temp } \\
{\left[{ }^{\circ} \mathrm{C}\right]}\end{array}$ & $\begin{array}{r}\mathrm{CO}_{2} \\
{[\mathrm{ppm}]}\end{array}$ & $\begin{array}{r}\mathrm{CO} \\
{[\mathrm{ppb}]}\end{array}$ & $\begin{array}{r}\mathrm{CN} \\
{\left[\mathrm{cm}^{-3}\right]}\end{array}$ & $\begin{array}{r}\mathrm{CN}, \text { Balbina } \\
{\left[\mathrm{cm}^{-3}\right]}\end{array}$ & $\begin{array}{l}\mathrm{CCN}_{0.6} \\
{\left[\mathrm{~cm}^{-3}\right]}\end{array}$ & $\begin{array}{r}\mathrm{CCN}_{0.6} / \mathrm{CN} \\
{[1]}\end{array}$ & $\begin{array}{r}\sigma_{\mathrm{sp}}(550 \mathrm{~nm}) \\
{\left[\mathrm{M} \mathrm{m}^{-1}\right]}\end{array}$ & $\begin{array}{c}\text { Ångström } \\
\text { exponent [1] }\end{array}$ \\
\hline \multirow[t]{6}{*}{ F01 } & \multirow[t]{6}{*}{ 04. Jul } & 2855 & 732 & 13.9 & 370 & 105 & 686 & & - & - & 3.9 & 3.1 \\
\hline & & 2210 & 785 & 17.1 & 372 & 104 & 937 & & - & - & 4.9 & 2.7 \\
\hline & & 1580 & 845 & 20.8 & 373 & 108 & 1207 & & - & - & 7.2 & 2.5 \\
\hline & & 960 & 910 & 24.7 & 373 & 111 & 1303 & & - & - & 8.3 & 2.3 \\
\hline & & 440 & 966 & 28.0 & 373 & 110 & 1301 & & - & - & 7.5 & 2.2 \\
\hline & & 210 & 990 & 29.5 & 372 & 109 & 1331 & - & - & - & 6.9 & 2.2 \\
\hline \multirow[t]{6}{*}{ F02 } & \multirow[t]{6}{*}{ 05. Jul } & 4500 & 608 & 6.2 & 377 & 101 & 872 & & - & - & 4.9 & 3.0 \\
\hline & & 2850 & 733 & 13.8 & 373 & 100 & 984 & & - & - & 5.4 & 2.7 \\
\hline & & 2200 & 793 & 17.1 & 372 & 108 & 1158 & & - & - & 6.6 & 2.6 \\
\hline & & 930 & 919 & 25.0 & 372 & 110 & 1270 & & - & - & 8.1 & 2.3 \\
\hline & & 460 & 966 & 28.8 & 372 & 109 & 1341 & & - & - & 7.6 & 2.2 \\
\hline & & 240 & 989 & 30.9 & 371 & 108 & 1324 & - & - & - & 7.0 & 2.2 \\
\hline \multirow[t]{2}{*}{ F03 } & \multirow[t]{2}{*}{ 07. Jul } & 2860 & 729 & 14.1 & 370 & 94 & 736 & & 482 & 0.7 & 2.9 & - \\
\hline & & 420 & 968 & 27.4 & 375 & 103 & 1348 & - & 647 & 0.5 & 8.5 & - \\
\hline F04 & 07. Jul & 490 & 967 & 28.1 & 370 & 94 & 947 & - & 570 & 0.6 & 4.7 & 1.4 \\
\hline \multirow[t]{6}{*}{ F05 } & \multirow[t]{6}{*}{ 08. Jul } & 2850 & 730 & 13.8 & 370 & 84 & 1142 & & - & - & 5.6 & 2.6 \\
\hline & & 2220 & 786 & 17.2 & 371 & 91 & 1205 & & - & - & 8.8 & 2.4 \\
\hline & & 1560 & 849 & 21.0 & 370 & 95 & 1354 & & - & - & 10.5 & 2.2 \\
\hline & & 930 & 913 & 24.9 & 369 & 94 & 1003 & & - & - & 7.5 & 1.8 \\
\hline & & 440 & 967 & 28.1 & 378 & 115 & 1289 & & - & - & 7.4 & 1.9 \\
\hline & & 180 & 995 & 29.8 & 376 & 115 & 1322 & - & - & - & 6.5 & 1.9 \\
\hline \multirow[t]{7}{*}{ F06 } & \multirow[t]{7}{*}{ 10. Jul } & 2870 & 724 & 13.4 & 370 & 96 & 503 & & 431 & 0.9 & 3.5 & 2.6 \\
\hline & & 2200 & 782 & 17.0 & 370 & 94 & 651 & & 561 & 0.9 & 3.8 & 2.5 \\
\hline & & 1580 & 842 & 20.5 & 370 & 96 & 877 & & 750 & 0.9 & 4.6 & 2.3 \\
\hline & & 1290 & 872 & 22.4 & 370 & 97 & 1083 & & 915 & 0.8 & 5.6 & 2.3 \\
\hline & & 920 & 908 & 24.6 & 367 & 109 & 1531 & & 1119 & 0.7 & 7.7 & 2.1 \\
\hline & & 430 & 960 & 27.7 & 367 & 105 & 1440 & & 993 & 0.7 & 6.4 & 1.9 \\
\hline & & 180 & 987 & 29.3 & 366 & 106 & 1704 & 1680 & 965 & 0.6 & 6.7 & 2.0 \\
\hline \multirow[t]{6}{*}{ F07 } & \multirow[t]{6}{*}{ 11. Jul } & 2860 & 729 & 13.7 & 371 & 88 & 527 & & 442 & 0.8 & 2.9 & 2.7 \\
\hline & & 2230 & 785 & 17.1 & 370 & 89 & 839 & & 810 & 1.0 & 6.6 & 2.4 \\
\hline & & 1570 & 848 & 20.9 & 371 & 98 & 1243 & & 1092 & 0.9 & 7.1 & 2.4 \\
\hline & & 940 & 911 & 24.7 & 374 & 106 & 1505 & & 1247 & 0.8 & 8.3 & 2.3 \\
\hline & & 440 & 964 & 27.9 & 375 & 106 & 1530 & & 1195 & 0.8 & 7.3 & 2.0 \\
\hline & & 190 & 991 & 29.6 & 373 & 108 & 1588 & 678 & 1107 & 0.7 & 7.0 & 2.0 \\
\hline \multirow[t]{6}{*}{ F08 } & \multirow[t]{6}{*}{ 11. Jul } & 2900 & 723 & 13.4 & 371 & 85 & 766 & & 647 & 0.8 & 3.9 & 2.4 \\
\hline & & 2250 & 780 & 16.8 & 371 & 88 & 854 & & 800 & 0.9 & 4.6 & 2.7 \\
\hline & & 1600 & 841 & 20.5 & 371 & 95 & 1090 & & 983 & 0.9 & 6.8 & 2.4 \\
\hline & & 930 & 909 & 24.6 & 370 & 99 & 1259 & & 1010 & 0.8 & 6.4 & 2.5 \\
\hline & & 470 & 957 & 27.5 & 371 & 117 & 1582 & & 1119 & 0.7 & 7.2 & 2.1 \\
\hline & & 210 & 986 & 29.3 & 370 & 108 & 1604 & 1449 & 1024 & 0.6 & 6.5 & 2.1 \\
\hline F09 & 12. Jul & $300-1000$ & 974 & 28.5 & 374 & 110 & 1545 & 1398 & 1205 & 0.8 & 8.7 & 2.1 \\
\hline F11 & 15. Jul & 320 & 977 & 28.7 & 373 & 111 & 1426 & 898 & 1041 & 0.7 & 8.0 & 2.1 \\
\hline \multirow[t]{3}{*}{ F12 } & 15. Jul & 1260 & 872 & 22.4 & 370 & 111 & 1517 & & 1220 & 0.8 & 6.8 & - \\
\hline & & 590 & 942 & 26.6 & 370 & 112 & 1593 & & 1207 & 0.8 & 8.9 & - \\
\hline & & 300 & 974 & 28.5 & 366 & 102 & 1428 & 1419 & 946 & 0.7 & 5.6 & 2.0 \\
\hline F13 & 16. Jul & 2860 & 726 & 13.6 & 370 & 98 & 574 & & 535 & 0.9 & 2.5 & 2.2 \\
\hline & & 330 & 974 & 28.5 & 373 & 105 & 897 & & 707 & 0.8 & & 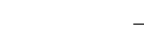 \\
\hline & & 210 & 987 & 29.3 & 367 & 107 & 801 & 1142 & 701 & 0.9 & 3.3 & 1.9 \\
\hline F14 & 17. Jul & 2810 & 733 & 13.6 & 371 & 91 & 661 & & 573 & 0.9 & 3.9 & 2.6 \\
\hline & & 2200 & 787 & 15.9 & 370 & 92 & 1038 & & 912 & 0.9 & 6.7 & 2.3 \\
\hline & & 1560 & 849 & 19.9 & 370 & 95 & 1244 & & 1043 & 0.8 & 8.6 & 2.2 \\
\hline & & 560 & 952 & 25.3 & 382 & 100 & 862 & & 687 & 0.8 & 5.7 & 1.9 \\
\hline & & 285 & 983 & 27.9 & 381 & 101 & 834 & & 740 & 0.9 & 4.7 & 1.6 \\
\hline & & 180 & 995 & 29.4 & 380 & 101 & 860 & & - & & 5.3 & 1.8 \\
\hline & & 150 & 997 & 29.2 & 377 & 104 & 864 & 554 & 590 & 0.7 & 5.3 & 2.1 \\
\hline
\end{tabular}


Table 1. Continued.

\begin{tabular}{|c|c|c|c|c|c|c|c|c|c|c|c|c|}
\hline $\begin{array}{l}\text { Flight } \\
{[\#]}\end{array}$ & $\begin{array}{l}\text { Date } \\
\text { [dd.mm] }\end{array}$ & $\begin{array}{r}\text { Altitude } \\
\text { [m a.s.l.] }\end{array}$ & $\begin{array}{l}\text { Press } \\
{[\mathrm{hPa}]}\end{array}$ & $\begin{array}{r}\text { Temp } \\
{\left[{ }^{\circ} \mathrm{C}\right]}\end{array}$ & $\begin{array}{r}\mathrm{CO}_{2} \\
{[\mathrm{ppm}]}\end{array}$ & $\begin{array}{r}\mathrm{CO} \\
{[\mathrm{ppb}]}\end{array}$ & $\begin{array}{r}\mathrm{CN} \\
{\left[\mathrm{cm}^{-3}\right]}\end{array}$ & $\begin{array}{r}\mathrm{CN} \text {,Balbina } \\
{\left[\mathrm{cm}^{-3}\right]}\end{array}$ & $\begin{array}{l}\mathrm{CCN}_{0.6} \\
{\left[\mathrm{~cm}^{-3}\right]}\end{array}$ & $\begin{array}{r}\mathrm{CCN}_{0.6} / \mathrm{CN} \\
{[1]}\end{array}$ & $\begin{array}{r}\sigma_{\mathrm{sp}}(550 \mathrm{~nm}) \\
{\left[\mathrm{M} \mathrm{m}^{-1}\right]}\end{array}$ & $\begin{array}{c}\text { Ångström } \\
\text { exponent [1] }\end{array}$ \\
\hline \multirow[t]{7}{*}{ F15 } & 17. Jul & 3840 & 645 & 9.1 & 371 & 82 & 584 & & 359 & 0.6 & 4.3 & 2.2 \\
\hline & & 2840 & 727 & 13.8 & 370 & 86 & 658 & & 549 & 0.8 & 2.0 & 1.1 \\
\hline & & 2210 & 783 & 16.9 & 370 & 89 & 762 & & 717 & 0.9 & 3.3 & 1.0 \\
\hline & & 1570 & 844 & 20.0 & 369 & 91 & 904 & & 817 & 0.9 & 6.4 & 2.2 \\
\hline & & 900 & 912 & 24.3 & 367 & 90 & 961 & & 783 & 0.8 & 5.7 & 1.8 \\
\hline & & 420 & 962 & 28.0 & 366 & 92 & 948 & & 677 & 0.7 & 5.2 & 1.8 \\
\hline & & 170 & 991 & 29.3 & 364 & - & 906 & 768 & 621 & 0.7 & 5.3 & 1.4 \\
\hline \multirow[t]{6}{*}{ F16 } & 18. Jul & 2850 & 727 & 14.2 & 369 & 74 & 478 & & 273 & 0.6 & 3.2 & 2.5 \\
\hline & & 2190 & 786 & 18.0 & 370 & 75 & 492 & & 264 & 0.5 & - & - \\
\hline & & 1560 & 846 & 21.0 & 369 & 74 & 786 & & 379 & 0.5 & - & - \\
\hline & & 910 & 913 & 23.8 & 371 & 77 & 697 & & 450 & 0.6 & 4.3 & 1.4 \\
\hline & & 450 & 962 & 27.7 & 374 & 81 & 694 & & 415 & 0.6 & 4.1 & 1.7 \\
\hline & & 180 & 991 & 30.8 & 372 & 82 & 713 & - & 383 & 0.5 & 3.7 & 2.0 \\
\hline \multirow{2}{*}{ F17 } & 18. Jul & 2870 & 724 & 14.3 & 370 & 72 & 411 & & 249 & 0.6 & 2.8 & 3.8 \\
\hline & & 180 & 989 & 32.2 & 367 & 83 & 782 & 817 & 490 & 0.6 & 2.3 & 0.6 \\
\hline \multirow[t]{5}{*}{ F18 } & 19. Jul & 1950 & 808 & 19.3 & 369 & 70 & 387 & & 267 & 0.7 & 3.6 & 1.6 \\
\hline & & 1230 & 880 & 22.5 & 368 & 74 & 1011 & & 704 & 0.7 & 4.0 & 1.9 \\
\hline & & 910 & 911 & 24.8 & 369 & 74 & 1143 & & 756 & 0.7 & 4.4 & 1.7 \\
\hline & & 600 & 945 & 27.2 & 370 & 78 & 1227 & & 692 & 0.6 & 5.1 & 1.8 \\
\hline & & 290 & 980 & 29.1 & 370 & 78 & 1243 & 1047 & 572 & 0.5 & 5.4 & 1.4 \\
\hline \multirow[t]{2}{*}{ F19 } & 19. Jul & 940 & 907 & 26.3 & 369 & 79 & 936 & & 602 & 0.6 & - & - \\
\hline & & 290 & 976 & 32.0 & 369 & 78 & 951 & 984 & 640 & 0.7 & - & - \\
\hline \multirow{6}{*}{ F20 } & 20. Jul & 2900 & 730 & 16.1 & 369 & 75 & 692 & & 392 & 0.6 & - & - \\
\hline & & 2250 & 782 & 18.4 & 369 & 77 & 965 & & 679 & 0.7 & - & - \\
\hline & & 1600 & 843 & 21.4 & 370 & 85 & 1421 & & 706 & 0.5 & - & - \\
\hline & & 930 & 906 & 25.0 & 372 & 90 & 1196 & & 750 & 0.6 & - & - \\
\hline & & 470 & 956 & 28.8 & 373 & 90 & 1144 & & 728 & 0.6 & - & - \\
\hline & & 240 & 974 & 30.2 & 372 & 89 & 1149 & 1073 & 611 & 0.5 & - & - \\
\hline \multirow[t]{6}{*}{ F21 } & 20. Jul & 2900 & 726 & 15.6 & 370 & 79 & 698 & & 465 & 0.7 & - & - \\
\hline & & 2250 & 781 & 17.2 & 371 & 91 & 1038 & & 832 & 0.8 & - & - \\
\hline & & 1600 & 830 & 21.0 & 371 & 94 & 1141 & & 858 & 0.8 & - & - \\
\hline & & 930 & 909 & 26.9 & 370 & 98 & 1240 & & 840 & 0.7 & - & - \\
\hline & & 470 & 955 & 31.1 & 370 & 98 & 1254 & & 698 & 0.6 & - & - \\
\hline & & 220 & 984 & 33.2 & 369 & 99 & 1310 & 1555 & 791 & 0.6 & - & - \\
\hline
\end{tabular}

travelling over a region that is comprised of a mix of rainforest and wetlands. Typical back-trajectories for this site and time period (5-17 July 2001) are shown in Kuhn et al. (2007), revealing footprint areas upwind of Manaus predominantly of pristine rainforest. Previous measurements in the Amazon Basin have shown that radiative cooling at dusk results in the formation of a shallow, decoupled nocturnal boundary layer over the forest, whilst heating of the surface in the morning causes a well mixed CBL to develop at a vertical growth rate of ca. $10 \mathrm{~m} \mathrm{~min}^{-1}$ (Garstang et al., 1988). The CBL heights, deduced from different airborne vertical profile measurements of potential temperature and other trace constituents during LBA-CLAIRE-2001, ranged between 500 and $1400 \mathrm{~m}$ (Kuhn et al., 2007), and were within the typical mixed layer heights that are expected above Amazonian tropical forests (Dias et al., 2002; Fisch et al., 2004).

\subsection{Flight track}

Figure 1 shows a 2-D map of the flight pattern of Flight \#18 overlaying the Manaus area land cover image, and also including the output of the HYSPLIT plume dispersion model for the time period of the airborne measurements (starting 10:00 LT, with $4 \mathrm{~h}$ run time). The latter closely resembles the observations as will be shown below. For better visualization of the flight track, a 3-D diagram with colour-coded flight altitudes and including the VOC cartridge sampling periods in some of the plume crosswind transects is given in Fig. 2. After takeoff at the airport of Manaus, the flight pattern was designed to conduct a Lagrangian experiment with a series of vertical profiles (3-6 crosswind transects each) at successive distances $(10,40,70$ and $100 \mathrm{~km})$ in the plume downwind of Manaus City. This way the aircraft was able to sample plume air masses with progressively increasing photochemical ages. Each of the 18 consecutive plume transects was 


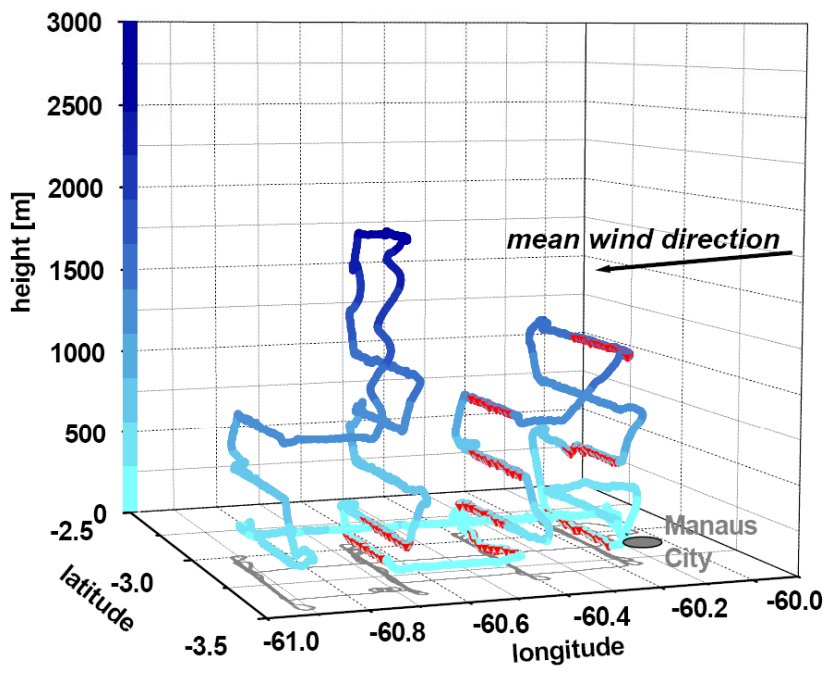

Fig. 2. 3-D plot of Flight \#18 on 19 July 2001. After takeoff at the airport of Manaus the flight pattern was set up as a Lagrangian experiment with a series of stacked horizontal profiles (with 3-6 crosswind transects each) in the urban outflow at successive distances downwind of Manaus City (10, 40, 70 and $100 \mathrm{~km})$. The flight altitude is colour-coded in blue (z-axis). Red lines indicate the VOC cartridge sample intervals within some of the plume transects. The grey line is the XY-projection as in Fig. 1.

accomplished at constant altitude and aircraft speed, approximately perpendicular to the longitudinal axis of the plume. Within a flight duration of ca. $4 \mathrm{~h}$, the plume was followed in westerly direction, with vertical profile transects alternating between ascending and descending. With the estimated CBL mean wind speed of $10 \mathrm{~m} \mathrm{~s}^{-1}$ (see above) the plume air parcels travelled slightly ahead of the aircraft's flight schedule.

The urban plume borders were distinct from the clean background air on either side of it. Predictions by the HYSPLIT dispersion model already indicated that under the prevailing meteorological conditions the plume was not significantly fragmented by turbulence (Fig. 1), with only low crosswind dispersion. This is also evidenced by the observed remarkable uniformity of concentration changes within the flight transects flown at different distances from Manaus (e.g. $\mathrm{CO}$ as non-reactive tracer in Figs. 4, 5).

In the absence of $\mathrm{NO}_{2}$ values for Flight \#18, due to a breakdown of the photolytic converter, the data collected during Flight \#11 (15 July 2001, 09:00-13:00 LT) are presented and used as a proxy to estimate the total $\mathrm{NO}_{\mathrm{x}}$ mixing ratios. Weather conditions during Flight \#11 were similar to those during Flight \#18, but winds speeds were lower $\left(2 \mathrm{~m} \mathrm{~s}^{-1}\right.$, measured $20 \mathrm{~m}$ above the forest canopy, K34, versus $3-5 \mathrm{~m} \mathrm{~s}^{-1}$ during Flight \#18), leading to faster photochemical aging with travel distance from Manaus. Here only three transects were at a similar altitude $(230-280 \mathrm{~m})$ at 10 , 40 and $70 \mathrm{~km}$ distance from Manaus.

\section{Results and discussion}

\subsection{Amazon background conditions (green ocean air)}

During LBA-CLAIRE-2001 the airborne measurements focussed on data collection around midday, as this is the photochemically most active period and typically the time of the most intense vertical mixing. To characterize the background conditions in the Manaus region during the wet-to-dry season transition period, vertical profiles of observed mixing ratios for $\mathrm{CO}, \mathrm{NO}, \mathrm{O}_{3}, \mathrm{CO}_{2}, \mathrm{H}_{2} \mathrm{O}, \mathrm{CN}, \mathrm{CCN}_{0.6}$, and the potential temperature from Flight \#18 are shown in Fig. 3; and for isoprene (the dominant biogenic VOC species) and $\alpha$-pinene (the dominant monoterpene species) the mean vertical profiles from 8 background flights during the LBA-CLAIRE2001 are shown. A summary of the complete set of measurements of long-lived trace gases and aerosols in the background atmosphere during LBA-CLAIRE-2001 is given in Table 1. As is shown by the dispersion model results in Fig. 1, the crosswind dispersion of the Manaus plume was low, therefore we were able to use data collected at either edge of each transect, during ascent or descent to the next flight altitude, to characterize the Manaus background air conditions. The mixing ratios outside of the plume were spatially quite uniform, comparing both the north-south gradient and the east-west gradient following the plume travel path with time. For most species, these background data resemble airborne measurements that were carried out at more remote regions to the north of Manaus City during LBA-CLAIRE2001. Only for the aerosol number concentrations are the levels at the edge of the plume somewhat elevated. This can be explained by the fact that the ratio between in-plume and background levels are highest (as much as a factor of 30) in the case of aerosol number concentration, so that even a slight amount of diffusion of plume air into the surroundings yields a detectable enhancement.

The uniformity of vertical profiles of most trace constituents in Fig. 3 is indicative of a well-mixed CBL, with mixing ratios representative for wet-season background conditions containing very low levels of pollution from biomass burning or industrial emissions. The vertical profiles of potential temperature and specific humidity in Fig. 3 indicate a CBL height of about $1400 \mathrm{~m} . \mathrm{CO}_{2}$ mixing ratios were in a range of 369-374 ppm, and quite constant above the CBL (see Lloyd et al., 2007 for more details on the $\mathrm{CO}_{2}$ profiles and budget).

CO mixing ratios on Flight \#18 were in the range of 70 $90 \mathrm{ppb}$ within the CBL and slightly decreasing with altitude. This is near the lower end of CO concentrations in the CBL observed during the campaign ( $78-115 \mathrm{ppb}$, see Table 1) and indicates that this flight fell into a relatively unpolluted period with values significantly lower than normally observed during the middle of the Amazon dry season (100600 ppb; Crutzen et al., 1985; Andreae et al., 1988; Kaufman et al., 1992; Blake et al., 1996; Sachse et al., 1988). 


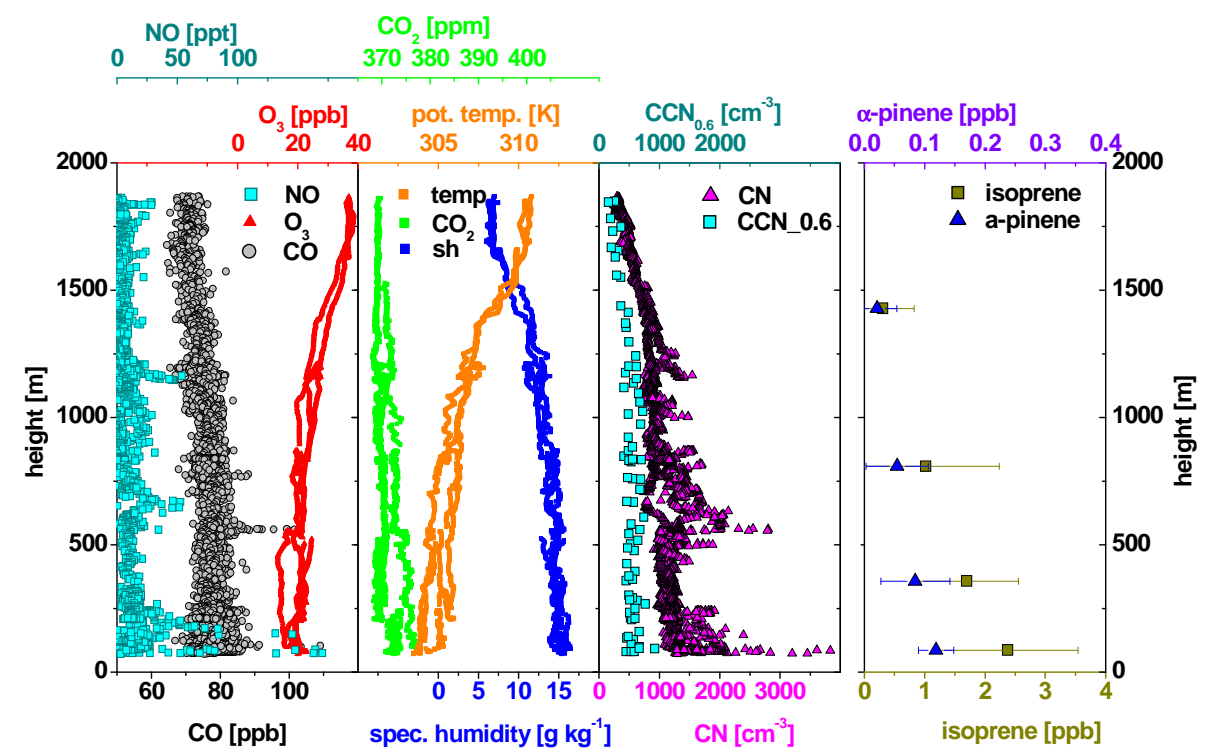

Fig. 3. Background concentrations of trace constituents and meteorological data measured during Flight \#18 on 19 July 10:00-14:00 LT. All data collected outside of the plume (i.e., at either side of each transect of the 18 transects, during ascending or descending to the next flight altitude) were merged. As there were no background VOC measurements within this specific flight, the mean vertical profiles of isoprene and $\alpha$-pinene from 8 background flights during the LBA-CLAIRE-2001 campaign are shown in the right panel (see Kuhn et al., 2007).

They are comparable to the values found over the Amazon Basin during the early dry season in 1985 and the wet season in 1987 (75-110 ppb) (Sachse et al., 1988; Harriss et al., 1990). Typical CO mixing ratios measured during July at Ascension Island, which also lies in the Southeast Trades, are $60-90 \mathrm{ppb}$ (data from NOAA-ESRL ftp://ftp.cmdl.noaa. gov/ccg/co/flask/event/). This suggests that little or no addition of $\mathrm{CO}$ from surface sources had taken place during the transit of the airmasses over the Amazon Basin in the case of Flight \#18, but that some additional CO may have been present during other periods of LBA-CLAIRE-2001. Some of this additional CO may have been the result of VOC oxidation. However, the fact that the highest $\mathrm{CO}$ values were observed during those parts of the campaign when the trajectories had passed the burning areas in Eastern Amazonia (Rissler et al., 2004) suggests that most of the enhancement was probably due to upwind pyrogenic emissions. This is supported by the correlation between $\mathrm{CN}$ and $\mathrm{CO}$ concentrations in the background air (see below).

The CBL background NO mixing ratios were mostly below the instrument's detection limit of $30 \mathrm{ppt}$, and slowly decreasing with altitude (Fig. 3), comparable to groundbased data measured by Cordova et al. (2004) and Moura et al. (2004) at an Amazonian forest site $150 \mathrm{~km}$ North of Manaus during the same time period. They are thus comparable to data within the atmospheric boundary layer and lower free troposphere in remote maritime locations (2040 ppt; Bottenheim et al., 1986; Bradshaw et al., 2000). This implies that the $\mathrm{NO}_{\mathrm{x}}$ mixing ratios during LBA-CLAIRE2001 over the Amazon forest were close to the threshold re- quired for net photochemical ozone formation (Chameides et al., 1992), and therefore very sensitive to anthropogenic pollution. Singh et al. (1990) reported a median NO concentration as low as $8 \mathrm{ppt}$ at $0-6 \mathrm{~km}$ altitude over the Amazon basin in April-May 1987 (wet season), with little vertical gradient. Torres and Buchan (1988) observed boundary layer NO concentrations in the range 25-60 ppt over the central Amazon in July-August 1985. Although the data base in tropical areas is still quite sparse, ground-based observations in the remote Amazon forest (not under the direct influence of biomass burning) appear to range from 20 to $100 \mathrm{ppt}$ of NO. The somewhat higher $\mathrm{NO}_{\mathrm{x}}$ concentrations found in tropical forests, as compared to those observed in remote marine locations could result from the primary continental sources of biomass burning or from $\mathrm{NO}_{\mathrm{x}}$ emissions by soil (Kaplan et al., 1988; Torres and Buchan, 1988; Gut et al., 2002; Ganzeveld et al., 2002; Rummel et al., 2002). Alternatively they may derive from lightning activity within thunderstorms as observed over southern Brazil by Huntrieser et al. (2007).

$\mathrm{O}_{3}$ mixing ratios varied from $18-24 \mathrm{ppb}$ within the background CBL (though one of 18 transects dropped down to $14 \mathrm{ppb}$ ) and were fairly constant with height in the lower CBL, although increasing to peak values of $38 \mathrm{ppb}$ above $1500 \mathrm{~m}$ altitude. The sources of ozone in the remote troposphere are downward transport from the stratosphere and in situ photochemical production. Losses result from photochemical processes and from deposition and destruction at the earth's surface. In the tropics, near the surface, the contribution by transport from the stratosphere is relatively 
minor and the ozone budget is largely controlled by photochemical processes, balanced by dry deposition (Roelofs and Lelieveld, 1997). Tropospheric ozone is an important player in atmospheric chemistry because $\mathrm{OH}$ radicals are generated from the photolysis of ozone (Lelieveld et al., 2008). $\mathrm{OH}$ is the principal oxidizing agent in the troposphere that dominates the daytime removal of most gaseous pollutants (dubbed the "detergent" of the atmosphere), but was not measured directly during LBA-CLAIRE-2001.

Background ambient air contains a suite of highly reactive biogenic VOC emitted by vegetation. VOC composition was dominated by isoprene, contributing up to $90 \%$ of the measured biogenic species, as typically found in tropical regions (e.g. Jacob and Wofsy, 1988; Kesselmeier et al., 2002; Kuhn et al., 2007; Karl et al., 2007). The mixing ratios of $\alpha$-pinene were an order of magnitude lower, and comprised about half of the sum of detected monoterpene species. The mean vertical profiles of isoprene and $\alpha$-pinene during LBA-CLAIRE2001 showed similar characteristics, both declining with altitude, and ranging from $4.7 \mathrm{ppb}$ for isoprene and $0.23 \mathrm{ppb}$ for $\alpha$-pinene to below detection limit for both compounds in the free troposphere (FT) (Fig. 3; Kuhn et al., 2007). As tropical ecosystems are characterized by both, high leaf area index and strong VOC emission factors (Rinne et al., 2002; Kuhn et al., 2007, Karl et al., 2007), also occurring all year round (Kuhn et al., $2004 \mathrm{a}, \mathrm{b}$ ), they are the major contributors to the global burden of biogenic VOC. For example, $83 \%$ isoprene, $69 \%$, and $66 \%$ of the global annual emissions of isoprene, monoterpenes, and methanol, respectively, are estimated to originate from the tropical regions $\left(30^{\circ} \mathrm{S}-30^{\circ} \mathrm{N}\right.$; Lathiere et al., 2006).

Aerosol concentrations during LBA-CLAIRE-2001 were somewhat elevated relative to truly unpolluted pristine rainforest values, with mean values of aerosol number concentrations $(\mathrm{CN})$ within the $\mathrm{CBL}$ of $700-1700 \mathrm{~cm}^{-3}$ and $\mathrm{CCN}_{0.6}$ concentrations of $400-1200 \mathrm{~cm}^{-3}$, both decreasing with altitude (Fig. 3, Table 1). The cleanest conditions during LBA-CLAIRE-2001 were reached after the aircraft campaign, during 23-25 July, when the average $\mathrm{CN}$ concentrations at Balbina were $513 \pm 160 \mathrm{~cm}^{-3}$. Values of 400 500 particles $\mathrm{cm}^{-3}$ are typical of unpolluted Amazonia in the absence of extensive precipitation (Roberts et al., 2001b; Andreae et al., 2004; Andreae, 2009; Martin et al., 2010a, b; Pöschl et al., 2010).

In general, the background aerosol concentrations obtained on the aircraft were in good agreement with simultaneous measurements made at a ground-based site, located at Balbina, some $125 \mathrm{~km}$ NE of Manaus (Table 1). During some flights the background $\mathrm{CN}$ concentrations measured on the aircraft were slightly higher than those measured at Balbina, which may have been due to the flights being located generally downwind of the Manaus region, where minor amounts of pollutants may have been present. Because of the very high aerosol enhancement in the Manaus plume relative to that of $\mathrm{CO}$ (average $\Delta \mathrm{CN} / \Delta \mathrm{CO}=340 \pm 230 \mathrm{~cm}^{-3} \mathrm{ppb}^{-1}$, see Sect. 3.6) a CN enhancement of about $200 \mathrm{~cm}^{-3}$, as was observed on Flight \#18, would correspond to a CO enhancement of less than $1 \mathrm{ppb}$, which could not be distinguished from the regional background.

The enhancements of $\mathrm{CO}$ and $\mathrm{CN}$ in the background air during LBA-CLAIRE-2001 are significantly correlated $\left(r^{2}=0.52\right)$ with a $\Delta \mathrm{CN} / \Delta \mathrm{CO}$ slope of $20 \pm 2 \mathrm{~cm}^{-3} \mathrm{ppb}^{-1}$, in good agreement with the $\mathrm{CN} / \mathrm{CO}$ emission ratios from biomass burning (Guyon et al., 2005). For an assumed CO background value of $70 \mathrm{ppb}$, the regression of $\mathrm{CN}$ on $\mathrm{CO}$ predicts a CN concentration of 509 particles $\mathrm{cm}^{-3}$, consistent with the background values observed during the clean period of 23-25 July and also during SMOCC-2002 (Andreae et al., 2004). The concentrations of $\mathrm{CO}$ and aerosols tended to decline with altitude from the CBL into the FT; the lowest values were reached during Flight \#18 in the FT (70 ppb). These observations suggest that during 18-19 July, a small enhancement of ca. $10 \mathrm{ppb} \mathrm{CO}$ and 200 particles $\mathrm{cm}^{-3}$ of $\mathrm{CN}$ was present as a result of pyrogenic emissions in eastern Amazonia.

An average of $66 \pm 15 \%$ of the $\mathrm{CN}$ present in the BL were $\mathrm{CCN}$ active at $0.6 \%$ super-saturation (SS) (Fig. 3, Table 1), and this fraction increased to $77 \pm 14 \%$ in the FT. This CCN fraction is in close accordance with Amazon background data measured during other campaigns under clean conditions (Roberts et al., 2003; Vestin et al., 2007; Gunthe et al., 2009; Martin et al., 2010a). Organic material, about half of which is water soluble, constitutes some $80 \%$ of the clean air (wet-season) aerosol mass in the Amazon Basin, while soluble inorganic salts (predominantly ammonium bisulphate) represent about $15 \%$. The organic and inorganic fractions, in spite of their different mass fractions, make similar contributions to the soluble molecules that account for the CCN activity of Amazon aerosols (Roberts et al., 2002; Martin et al., 2010a).

At the low natural levels of ozone and $\mathrm{NO}_{\mathrm{x}}$ typical of the unpolluted tropical atmosphere, the oxidation of biogenic VOC proceeds mostly through reaction with $\mathrm{OH}$ and has a low aerosol and CCN yield. Under these low CCN conditions, cloud droplets can grow rapidly to the size where precipitation occurs ("warm rain" formation), and it has been observed that the precipitation from convection over tropical Amazonia is more of a maritime type (Dias et al., 2002; Williams et al., 2002; Andreae et al., 2004). At such low $\mathrm{CCN}$ concentrations, cloud properties (e.g., droplet effective radius and maximum supersaturation) are most sensitive to an increase in CCN (Roberts et al., 2001, 2003). Therefore, enhanced aerosol emissions due to human activity in the Amazon Basin may have a stronger impact on climate than emissions in other continental regions.

The light scattering coefficients, $\sigma_{\mathrm{sp}}$, at $550 \mathrm{~nm}$ in the CBL were typically in the range $5-10 \mathrm{Mm}^{-1}$. They were about $30-50 \%$ lower than measured simultaneously at a groundbased site in Balbina (unpublished data). This is most likely a consequence of low efficiency of the aircraft's aerosol inlet 
for large particles, as the coarse aerosol fraction accounts for about half of the light scattering of the background Amazonian aerosol (Guyon et al., 2003). The lowest values of $\sigma_{\mathrm{sp}}$ were measured during the clean period when Flight \#18 took place. The Ångström coefficients were typically around 2, which also suggests that light scattering was mostly due to the fine mode aerosol.

\subsection{Air pollutants within the Manaus plume}

Figure 4 shows the time series of the airborne measurements obtained for Flight \#18, including the complete chronology of all plume transects at different altitudes and distances from Manaus. Within the plume, mixing ratios of $\mathrm{CO}, \mathrm{O}_{3}$ and NO were drastically enhanced compared to background air. Peak values within the plume of $140 \mathrm{ppb} \mathrm{CO}$ were observed in the vicinity $(10 \mathrm{~km}$ distance $)$ of the city, but remained fairly constant with time when travelling downwind of Manaus. Only little plume dilution occurred for the long-lived trace gases like $\mathrm{CO}$, this also being reflected by the $\mathrm{CCN}$ measurements. The $\mathrm{CCN}_{0.6}$ concentrations peaked at 2000 2500 particles $\mathrm{cm}^{-3}$ on all transects, and total aerosol number concentrations $(\mathrm{CN})$ were close to 30000 particles $\mathrm{cm}^{-3}$ for the plume transects at $10 \mathrm{~km}$ distance. Extrapolation using $\mathrm{CN} / \mathrm{CO}$ correlations suggests similar $\mathrm{CN}$ concentrations in the downwind transects where peak concentrations were not measured due to instrumental problems. These concentrations are comparable to the levels found in megacities such as Beijing (Wehner et al., 2008, and references therein).

Table 2 contains an overview of all the plume encounters made during the LBA-CLAIRE-2001 flights. The first part of the table provides information on the Manaus plume, the second shows results from some biomass burning plumes that were incidentally sampled during the flights. While the enhancement of $\mathrm{CO}$ in the plumes was always very obvious, the combustion-derived $\mathrm{CO}_{2}$ could not always be readily distinguished from background fluctuations resulting from biospheric fluxes. $\Delta \mathrm{CO} / \Delta \mathrm{CO}_{2}$ enhancement ratios could therefore not always be determined, and in some cases might be biased by high $\mathrm{CO}_{2}$ in residual night time air. This is especially problematic during morning flights (Guyon et al., 2005). Nevertheless, it is quite clear from the data in Table 2 that the urban emissions had much lower $\mathrm{CO}$ enhancement ratios $\left(11.3 \pm 10.9 \times 10^{-3}\right)$ than the biomass plumes $\left(77 \pm 40 \times 10^{-3}\right.$ during LBA-CLAIRE-2001, similar to previous observations of pyrogenic emissions, Andreae and Merlet, 2001). The lowest $\Delta \mathrm{CO} / \Delta \mathrm{CO}_{2}$ ratios (around $1 \times 10^{-3}$ ) were found when the aircraft sampled emissions from the power plants (pin symbols in Fig. 1), e.g., on Flights 6 and 11 (Table 2). Efficiently operating power plants are known to emit very little $\mathrm{CO}$, often with $\Delta \mathrm{CO} / \Delta \mathrm{CO}_{2}$ less than $1 \times 10^{-3}$, but emissions can be higher when operating conditions are not optimal (EPA AP-42; Nicks et al., 2003).

It is noteworthy that the $\mathrm{CO}$ enhancement ratios in the Manaus plume are similar to the values of around $10 \times 10^{-3}$

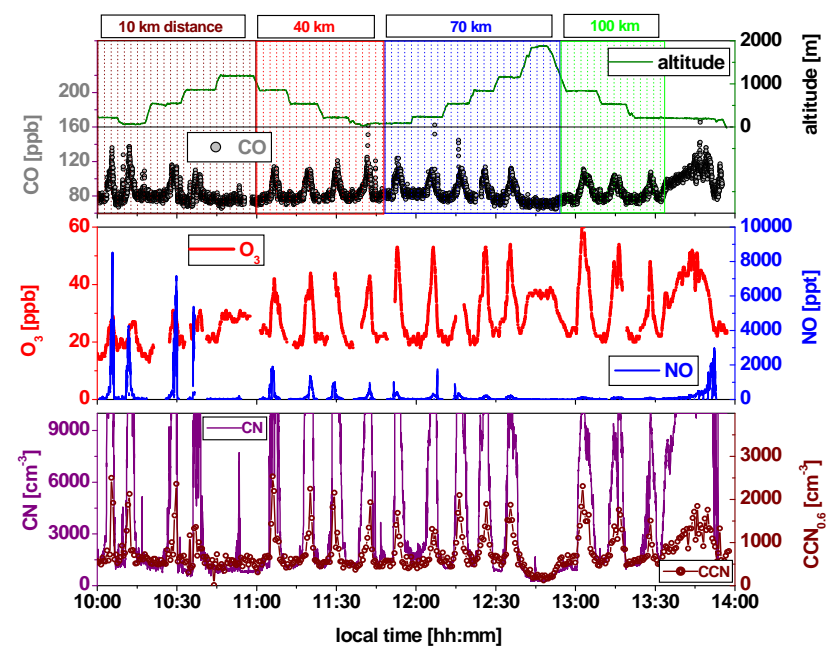

Fig. 4. Complete time series of trace constituent measurements on plume transects during Flight \#18 on 19 July 10:00-14:00 LT. Vertical profiles of crosswind transects in the urban outflow are shown for successive distances (10, 40, 70 and $100 \mathrm{~km})$ downwind of Manaus City. The rightmost sections of the diagrams show the flight back to Manaus at the $200 \mathrm{~m}$ level (crossing the plume approx. perpendicularly). $\mathrm{CN}$ data were cut off at $10000 \mathrm{~cm}^{-3}$ for most of the flight; only the first transects were recorded in full scale with values up to $30000 \mathrm{~cm}^{-3}$ (data not shown).

that are typical for North American urban plumes (Potosnak et al., 1999; Schwarz et al, 2008). This implies that the vehicle fleet in Manaus is quite modern (in agreement with informal observations in the streets of Manaus), more comparable to, for example, Houston with a $\Delta \mathrm{CO} / \Delta \mathrm{CO}_{2}$ of $1-3 \times 10^{-3}$ (G. Frost, personal communication, 2007) than with Mexico City with a mean $\Delta \mathrm{CO} / \Delta \mathrm{CO}_{2}$ of $96 \times 10^{-3}$ (Jiang et al., 2005). The variability seen in the $\mathrm{CO}$ enhancement ratios in Table 2 therefore most likely reflects mixtures of varying proportions of power plant, vehicular and wood burning emissions.

In contrast to the non-reactive components, the mixing ratios of reactive compounds changed significantly with distance from their source. Peak values $>9 \mathrm{ppb}$ NO were found close to Manaus, decreasing strongly with the plume photochemical age further downwind. The NO data at 40 and $70 \mathrm{~km}$ distance are comparable to wet season pollution data reported by Pickering et al. (1992), who observed $>1 \mathrm{ppb}$ of NO during one aircraft intercept of the Manaus effluent at $50 \mathrm{~km}$ downwind distance. In the proximity of the urban sources, $\mathrm{NO}$ and $\mathrm{NO}_{2}$ are assumed to be the dominant constituents of the total reactive nitrogen $\left(\mathrm{NO}_{\mathrm{y}}=\right.$ sum of $\mathrm{NO}_{\mathrm{x}}$, $\mathrm{HNO}_{3}, \mathrm{NO}_{3}, \mathrm{~N}_{2} \mathrm{O}_{5}, \mathrm{HONO}, \mathrm{PAN}$, and other organic nitrogen compounds). As shown in Fig. 4 (see also Fig. 6), ozone mixing ratios increased with decreasing $\mathrm{NO}$, with peak values of $\mathrm{O}_{3}(65 \mathrm{ppb})$ measured at the furthest distance sampled $(100 \mathrm{~km})$. Figures 5 and 6 show the geographic distribution of the Manaus plume in terms of $\mathrm{CN}, \mathrm{CO}, \mathrm{NO}$ and $\mathrm{O}_{3}$ mixing 
Table 2. Overview of all the plume encounters made during the LBA-CLAIRE-2001 flights (Manaus plumes in the upper part, and biomass burning plumes in the lower part). PP means that power plant plume was sampled, based on trajectory analysis. $\sigma_{\mathrm{sp}}(550 \mathrm{~nm})$ is the scattering coefficient at $550 \mathrm{~nm}$ wavelength. All concentrations and scattering coefficients have been normalized to standard conditions in dry air $(273.15 \mathrm{~K}, 1000 \mathrm{hPa})$.

\begin{tabular}{|c|c|c|c|c|c|c|c|c|c|c|c|c|}
\hline $\begin{array}{l}\text { Flight } \\
\text { [\#-transect] }\end{array}$ & PP & $\begin{array}{l}\text { Longitude } \\
\qquad\left[^{\circ} \mathrm{W}\right]\end{array}$ & $\begin{array}{l}\text { Altitude } \\
\text { [m a.s.l.] }\end{array}$ & $\begin{array}{l}\text { Press } \\
{[\mathrm{hPa}]}\end{array}$ & $\begin{array}{l}\text { Temp } \\
{\left[{ }^{\circ} \mathrm{C}\right]}\end{array}$ & $\begin{array}{c}\Delta \mathrm{CO} / \\
\Delta \mathrm{CO}_{2} \\
{\left[10^{-3}\right]}\end{array}$ & $\begin{array}{r}\Delta \mathrm{CN} / \\
\Delta \mathrm{CO} \\
{[1]}\end{array}$ & $\begin{array}{r}\sigma_{\mathrm{sp}} / \\
\mathrm{CO} \\
{[1]}\end{array}$ & $\begin{array}{r}\sigma_{\mathrm{sp}} / \\
\mathrm{CN} \\
{\left[10^{3}\right]}\end{array}$ & $\begin{array}{r}\text { Ångstrom } \\
\text { exponent } \\
{[1]}\end{array}$ & $\begin{array}{r}\Delta \mathrm{CCN}_{0.6} / \\
\Delta \mathrm{CN} \\
{[1]}\end{array}$ & $\begin{array}{r}\Delta \mathrm{CCN}_{0.6} \\
\Delta \mathrm{CO} \\
{[1]}\end{array}$ \\
\hline $\begin{array}{l}\text { Urban } \\
\text { Plumes: }\end{array}$ & & & & & & & & & & & & \\
\hline F01-1 & & 60.60 & 270 & 984 & 28.0 & - & 109 & 0.17 & 1.86 & 2.4 & - & - \\
\hline F02-2 & & 60.20 & 420 & 970 & 30.2 & - & 317 & 0.44 & 0.47 & 2.2 & - & - \\
\hline F06-2 & PP & 60.19 & 310 & 975 & 31.0 & 1.2 & 826 & - & - & 2.1 & 0.08 & - \\
\hline F07-2 & & 60.88 & 320 & 976 & 30.4 & 6.0 & 225 & - & - & 2.3 & 0.15 & 38.27 \\
\hline F08-1\&2 & & near K34 & $200-930$ & 959 & 29.0 & - & 81 & 0.54 & 3.22 & 2.3 & 0.48 & 37.58 \\
\hline F08-3 & & 60.10 & 290 & 963 & 29.2 & - & - & - & 1.31 & 2.1 & 0.09 & - \\
\hline F09A & & 60.17 & 300 & 979 & 29.6 & - & 306 & 0.11 & 0.92 & 2.1 & 0.31 & 12.56 \\
\hline $\mathrm{F} 09 \mathrm{H}$ & & 60.21 & 300 & 979 & 29.6 & - & 290 & 0.22 & 0.68 & 2.1 & 0.15 & 36.44 \\
\hline F09I & & 60.21 & 300 & 979 & 29.6 & - & 364 & 0.22 & 0.33 & 2.3 & 0.14 & 45.84 \\
\hline F09C & & 60.26 & 300 & 979 & 29.6 & - & 130 & 0.13 & 1.14 & 2.2 & 0.22 & 22.30 \\
\hline F09B & & 60.31 & 300 & 979 & 29.6 & 4.1 & 97 & 0.29 & 2.33 & 2.2 & 0.31 & 55.34 \\
\hline F09D & & 60.34 & 630 & 945 & 26.6 & - & 124 & 0.23 & 1.01 & 2.3 & 0.09 & 35.88 \\
\hline F09F & & 60.34 & 300 & 979 & 29.6 & - & 133 & 0.31 & 1.74 & 2.3 & 0.36 & 62.70 \\
\hline F09G & & 60.34 & 300 & 979 & 29.6 & - & 240 & 0.49 & 1.35 & 2.3 & 0.35 & 85.68 \\
\hline F09E & & 60.58 & 300 & 979 & 29.6 & - & 100 & 0.57 & 2.57 & 2.3 & 0.47 & 48.67 \\
\hline F11-1N & & 60.18 & $180-910$ & 951 & 27.1 & 4.9 & 93 & 0.10 & 0.86 & 2.0 & 0.13 & 27.52 \\
\hline F11-1S & PP & 60.17 & $180-910$ & 951 & 27.1 & 1.4 & 462 & - & - & 2.2 & 0.14 & 37.30 \\
\hline F11-5 & & 60.17 & 370 & 972 & 29.7 & - & - & - & 0.51 & 2.2 & 0.11 & - \\
\hline F11-2 & & 60.42 & $140-170$ & 944 & 27.4 & 2.0 & 327 & 0.08 & 0.38 & 2.1 & 0.22 & 90.92 \\
\hline F11-4 & & 60.42 & 340 & 977 & 30.2 & 3.4 & 233 & - & 0.48 & 2.1 & 0.21 & 76.47 \\
\hline F11-3 & PP & 60.67 & 320 & 977 & 30.2 & 0.8 & 372 & - & - & 2.2 & 0.43 & 159.07 \\
\hline F12-1A & & 60.17 & 300 & 972 & 28.9 & - & 196 & - & 0.65 & 1.2 & 0.08 & 19.79 \\
\hline F12-1B & & 60.16 & 305 & 972 & 28.9 & - & 302 & 0.24 & - & - & - & - \\
\hline F12-2 & & 60.17 & 620 & 939 & 27.5 & - & 246 & 0.29 & 0.46 & - & 0.05 & 14.53 \\
\hline F12-5A & & 60.42 & 600 & 941 & 27.8 & - & 184 & 0.61 & 0.62 & - & 0.08 & 17.57 \\
\hline F18-1 & $\mathrm{PP}$ & 60.17 & $100-1250$ & 938 & 26.1 & - & 827 & 0.11 & 0.15 & 1.6 & 0.03 & 68.91 \\
\hline F18-2 & PP & 60.40 & $100-1250$ & 960 & 28.1 & - & 885 & 0.13 & 0.16 & 1.8 & 0.07 & 77.01 \\
\hline F18-3 & & 60.67 & $150-1260$ & 941 & 27.3 & - & 713 & 0.14 & 0.18 & 2.0 & 0.05 & 75.96 \\
\hline F18-4 & & 60.92 & $290-910$ & 950 & 29.1 & 23.9 & 507 & 0.14 & 0.28 & 2.0 & 0.12 & 69.91 \\
\hline F19-1 & & 60.17 & $290-950$ & 950 & 29.1 & 15.1 & 680 & 0.13 & 0.19 & 1.9 & 0.04 & 40.78 \\
\hline F19-2 & & 60.42 & $290-950$ & 939 & 28.2 & 8.4 & 698 & 0.17 & 0.29 & 2.2 & 0.08 & 53.00 \\
\hline F19-3S & & 60.67 & $290-950$ & 937 & 28.4 & 32.0 & 427 & - & - & - & 0.08 & 33.10 \\
\hline F19-3N & & 60.67 & $290-950$ & 937 & 28.4 & 5.8 & 554 & - & - & - & 0.08 & 51.10 \\
\hline F20-1N & & 60.18 & $330-640$ & 986 & 29.1 & 19.7 & 116 & - & - & - & 0.10 & 12.80 \\
\hline F20-1S & PP & 60.18 & $330-640$ & 986 & 29.1 & - & 259 & - & - & - & 0.25 & 91.00 \\
\hline $\mathrm{F} 20-2 \mathrm{~N}$ & & 60.30 & $330-640$ & 986 & 30.3 & - & 200 & - & - & - & 0.07 & 14.60 \\
\hline F20-2S & PP & 60.30 & $330-640$ & 986 & 30.3 & 4.5 & 372 & - & - & - & 0.16 & 69.00 \\
\hline F20-3 & & 60.42 & $330-640$ & 959 & 27.9 & 5.1 & 238 & - & - & - & 0.21 & 57.00 \\
\hline F21-1 & & 60.18 & $300-1080$ & 927 & 27.7 & 16.0 & 620 & - & - & - & 0.04 & 30.50 \\
\hline F21-2 & & 60.42 & $470-1420$ & 912 & 26.6 & 26.4 & 239 & - & - & - & 0.11 & 29.80 \\
\hline F21-3 & & 60.67 & $480-940$ & 930 & 28.2 & - & 206 & - & - & - & 0.11 & 25.00 \\
\hline F21-4 & & $60.65-60.12$ & 600 & 943 & 29.0 & 33.7 & 268 & - & - & - & 0.07 & 28.30 \\
\hline Average & & & & & & 11.3 & 339 & 0.25 & 0.93 & 2.1 & 0.16 & 48.67 \\
\hline Std. Dev. & & & & & & 10.9 & 225 & 0.16 & 0.82 & 0.2 & 0.12 & 30.04 \\
\hline
\end{tabular}


Table 2. Continued.

\begin{tabular}{|c|c|c|c|c|c|c|c|c|c|c|c|c|}
\hline $\begin{array}{l}\text { Flight } \\
\text { [\#-transect] }\end{array}$ & PP & $\begin{array}{l}\text { Longitude } \\
\qquad\left[^{\circ} \mathrm{W}\right]\end{array}$ & $\begin{array}{l}\text { Altitude } \\
\text { [m a.s.1.] }\end{array}$ & $\begin{array}{l}\text { Press } \\
{[\mathrm{hPa}]}\end{array}$ & $\begin{array}{l}\text { Temp } \\
{\left[{ }^{\circ} \mathrm{C}\right]}\end{array}$ & $\begin{array}{c}\Delta \mathrm{CO} / \\
\Delta \mathrm{CO}_{2} \\
{\left[10^{-3}\right]}\end{array}$ & $\begin{array}{r}\Delta \mathrm{CN} / \\
\Delta \mathrm{CO} \\
{[1]}\end{array}$ & $\begin{array}{r}\sigma_{\mathrm{sp}} / \\
\mathrm{CO} \\
{[1]}\end{array}$ & $\begin{array}{r}\sigma_{\mathrm{sp}} / \\
\mathrm{CN} \\
{\left[10^{3}\right]}\end{array}$ & $\begin{array}{r}\text { Ångstrom } \\
\text { exponent } \\
{[1]}\end{array}$ & $\begin{array}{r}\Delta \mathrm{CCN}_{0.6} / \\
\Delta \mathrm{CN} \\
{[1]}\end{array}$ & $\begin{array}{r}\Delta \mathrm{CCN}_{0.6} / \\
\Delta \mathrm{CO} \\
{[1]}\end{array}$ \\
\hline \multicolumn{13}{|l|}{ Biomass } \\
\hline $\begin{array}{l}\text { Burning Plu } \\
\text { F06-01 }\end{array}$ & & 60.12 & 306 & 976 & 31.1 & 66.6 & 54 & 0.75 & 1.28 & 2.9 & - & - \\
\hline F07-1 & & 60.88 & 320 & 976 & 30.4 & 18.9 & 35 & 0.16 & 2.90 & 2.2 & 0.49 & 16.63 \\
\hline F12-1C & & 60.17 & 320 & 972 & 29.2 & 109.7 & 58 & 0.15 & 2.40 & - & - & - \\
\hline F12-5B & & 60.42 & 600 & 941 & 27.5 & 119.7 & 48 & 0.29 & 5.10 & - & 0.64 & 31.60 \\
\hline F19-3B & & 60.67 & $290-950$ & 937 & 28.4 & 69.7 & 54 & 0.28 & 6.10 & - & 0.72 & 29.80 \\
\hline Average & & & & & & 76.9 & 50 & 0.33 & 3.56 & 2.6 & 0.62 & 26.01 \\
\hline Std. Dev. & & & & & & 40.1 & 9 & 0.25 & 1.99 & 0.5 & 0.11 & 8.17 \\
\hline
\end{tabular}

ratios. The width of the urban plume was about $20-25 \mathrm{~km}$, resembling the dimension of the city itself, with little downwind spreading (see also the HYSPLIT dispersion model in Fig. 1).

\subsection{Observation-based ozone production rates within the plume}

Peak ozone mixing ratios on Flight \#18 reached up to $65 \mathrm{ppb}$ at the 850-m level at $100 \mathrm{~km}$ distance of Manaus City, which represents a more than 3-fold enhancement with respect to the background values ( $21 \mathrm{ppb}$ at either edge of this transect). The dependence of the production of ozone, $P\left(\mathrm{O}_{3}\right)$, on precursors is controlled by the primary radical sources, which in turn is dependent on both, the $\mathrm{NO}_{\mathrm{x}}$ availability and the VOC reactivity, and is non-linear with respect to emission strengths (Liu et al., 1987; Daum et al., 2000; Ryerson et al., 2003; Kleinman et al., 2003). Ozone precursors are ubiquitously emitted in urban areas, the major source categories being vehicles, power plants, and solvent use. Essentially all photochemical production of $\mathrm{O}_{3}$ in the troposphere occurs by the reactions in Eqs. (1-3), where the oxidation of NO takes place by reaction with the hydroperoxy radical $\left(\mathrm{HO}_{2}\right)$ and organic peroxy radicals $\left(\mathrm{RO}_{2}\right)$ formed by the reaction of $\mathrm{OH}$ with VOCs. The product $\mathrm{NO}_{2}$ photodissociates to recycle $\mathrm{NO}$ and an $\mathrm{O}$ atom, which immediately combines with $\mathrm{O}_{2}$ to yield $\mathrm{O}_{3}$. This way, $\mathrm{NO}_{\mathrm{x}}$ acts as a catalyst in the ozone formation process (e.g., Trainer et al., 2000).

$\mathrm{OH}+\mathrm{VOC}($ or $\mathrm{CO})+\mathrm{O}_{2} \rightarrow \mathrm{RO}_{2}+\mathrm{H}_{2} \mathrm{O}\left(\right.$ or $\left.\mathrm{HO}_{2}+\mathrm{CO}_{2}\right)$

$\mathrm{RO}_{2}+\mathrm{O}_{2}\left(\right.$ or $\left.\mathrm{HO}_{2}\right)+\mathrm{NO} \rightarrow$ Carbonyl $+\mathrm{HO}_{2}($ or $\mathrm{OH})+\mathrm{NO}_{2}(2)$

$\mathrm{NO}_{2}+\mathrm{hv}\left(+\mathrm{O}_{2}\right) \rightarrow \mathrm{NO}+\mathrm{O}_{3}$

Ultimately, $P\left(\mathrm{O}_{3}\right)$ depends on the mixing ratio of $\mathrm{NO}$ and the peroxy radicals (determined by the rate at which $\mathrm{OH}$ reacts with VOCs in the VOC-sensitive case). $\mathrm{O}_{3}$ production can
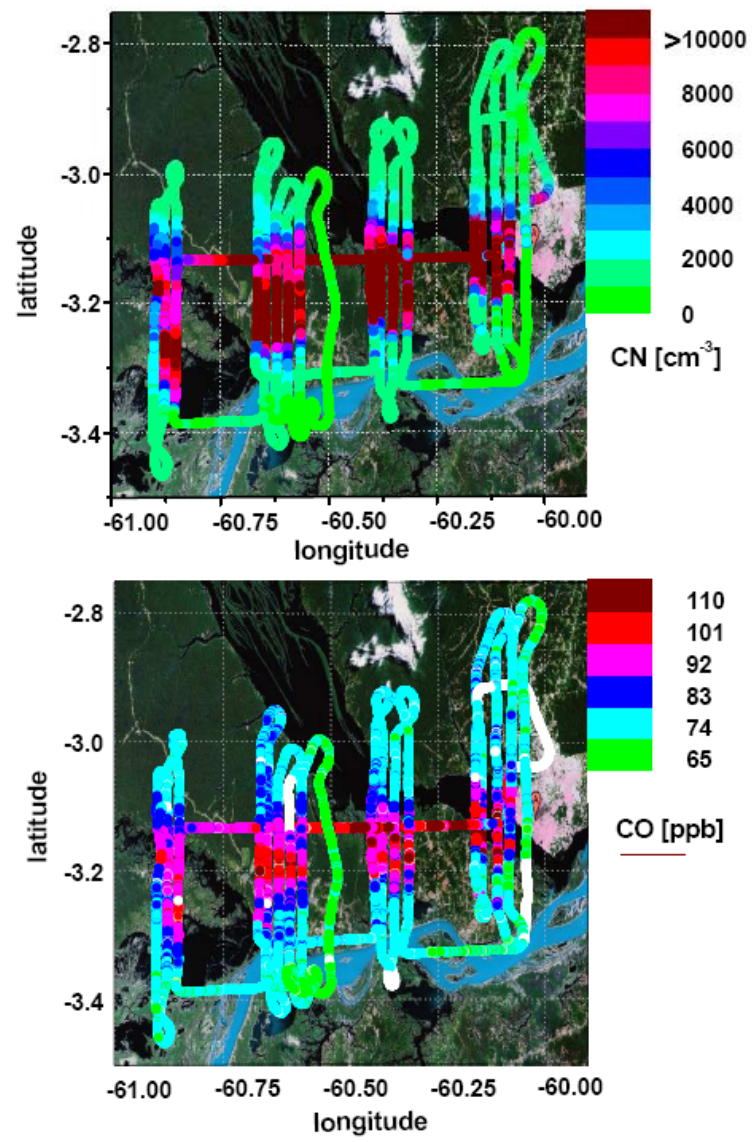

Fig. 5. Bird view image (see Fig. 1) of the total aerosol number concentration $(\mathrm{CN})$ and $\mathrm{CO}$ mixing ratios observed downwind of Manaus City $\left(-3.08^{\circ},-60.01^{\circ}\right)$ during Flight \#18 on 19 July 2001 , 10:00-14:00 LT As flight legs at a certain distance of Manaus lie on top of each other (compare Figs. 1,2), perspective is added in a way that highest altitudes transects are displayed on most right-hand side. One longitudinal degree corresponds to $\sim 111 \mathrm{~km}$. 
thus be considered as a radical competition process, in which VOCs and $\mathrm{NO}_{\mathrm{x}}$ compete for the $\mathrm{OH}$ radical. In Fig. 6, an anticorrelated evolution of $\mathrm{NO}$ versus $\mathrm{O}_{3}$ is shown, indicating the conversion of $\mathrm{NO}$ to $\mathrm{NO}_{2}$ during photochemical processing, and the removal of $\mathrm{NO}_{\mathrm{x}}$ from the photochemical cycle by oxidation to $\mathrm{HNO}_{3}$, peroxyacyl nitrates (PAN) or other organic nitrates (unfortunately neither $\mathrm{NO}_{2}$, nor $\mathrm{NO}_{\mathrm{y}}$ were available for Flight \#18). Neglecting the influence of plume dilution (horizontal dispersion and vertical entrainment), deposition (dry and wet), and aerosol surface reactions, a lower bound estimate of the amount of $\mathrm{O}_{3}$ formed over the observation period (between initial time $t_{0}$ of the first transect and time $t_{i}$ further downwind) should be approximately equal to the $\mathrm{O}_{3}$ enhancement, or

$$
\left[\mathrm{O}_{3}\left(t_{i}\right)\right]-\left[\mathrm{O}_{3}\left(t_{0}\right)\right]=\int_{t_{0}}^{t_{i}} P\left(\mathrm{O}_{3}\left(t^{\prime}\right)\right) d t^{\prime}
$$

The observed net ozone production rates approximated from the change in observed peak $\mathrm{O}_{3}$ mixing ratios at different distances from the source (Fig. 4), were $10-15 \mathrm{ppbh}^{-1}$ between 10 and $40 \mathrm{~km}$ and between 40 and $70 \mathrm{~km}$ distance, and around $0-15 \mathrm{ppbh}^{-1}$ between 70 and $100 \mathrm{~km}$ distance (where high production was observed at the uppermost altitude, but no further increase of $\mathrm{O}_{3}$ at the $200-550 \mathrm{~m}$ level). A peak value of $63 \mathrm{ppb} \mathrm{O}_{3}$ was reached at $100 \mathrm{~km}$ distance from Manaus at $850 \mathrm{~m}$ altitude, with $21 \mathrm{ppb}$ in the adjacent background. Assuming a mean plume travel time of $2.8 \mathrm{~h}$ and a CBL wind speed of $10 \mathrm{~m} \mathrm{~s}^{-1}$, we estimate an observationbased $\mathrm{O}_{3}$ net production rate of $15 \mathrm{ppbh}^{-1}$ for the entire observed travel path at the $850 \mathrm{~m}$ level. The vertical gradient in observed ozone enhancement underscores the finding of Pickering et al. (1992) that convective transport away from the surface enables precursor compounds to achieve their full ozone generating potential.

These $P\left(\mathrm{O}_{3}\right)$ are comparable to values of $12-14 \mathrm{ppb} \mathrm{h}^{-1}$, estimated for ozone production in the New York City plume in July 1996 (Kleinman et al., 2000), and with other high ozone production episodes in the vicinity of US cities (a comparison of five different cities, with a variety of background conditions, is given by Kleinman et al., 2005). Likewise, for the Lombardy region with the city Milan in its centre being one of the most economically important areas in Europe, estimated $P\left(\mathrm{O}_{3}\right)$ of $5-25 \mathrm{ppb} \mathrm{h}^{-1}$, have been reported (May/June 1998; Dommen et al., 2002; Spirig et al., 2002).

The evolution of the $\mathrm{O}_{3}$ mixing ratios is determined by the net photochemical ozone production (or destruction), deposition and dilution processes, and through entrainment of unpolluted (low $\mathrm{O}_{3}$ ) air. The latter can be accounted for by using the observed correlation between $\mathrm{O}_{3}$ and $\mathrm{CO}$. Carbon monoxide is a tracer of anthropogenic emissions with wellknown sources from combustion, industry, and oxidation of hydrocarbons. Because of its long chemical lifetime and relatively small biogenic exchange rates, it can be assumed that after emission only dilution by dispersion will modify
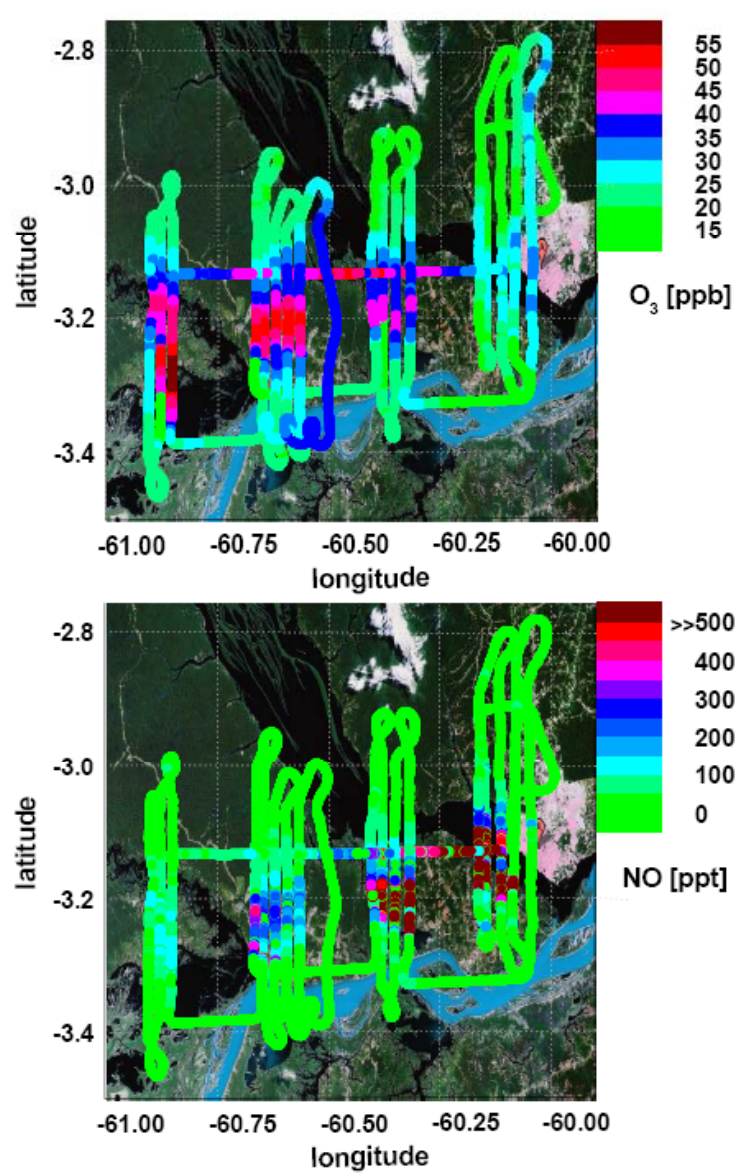

Fig. 6. Bird view image (see Fig. 1) of $\mathrm{O}_{3}$ and $\mathrm{NO}$ mixing ratios observed downwind of Manaus City $\left(-3.08^{\circ},-60.01^{\circ}\right)$ during Flight \#18 on 19 July 2001, 10:00-14:00 LT. The linear colour code of NO (lower panel) was selected to resolve values of 0-500 ppt, while the dark red colour in the vicinity of Manaus City includes values up to $10 \mathrm{ppb}$ of $\mathrm{NO}$ (see Fig. 4). For $\mathrm{O}_{3}$ (upper panel) one transect (70 km distance, $550 \mathrm{~m}$ level) was interpolated due to lack of data. As flight legs at a certain distance of Manaus lie on top of each other (compare Figs. 1, 2), perspective is added in a way that highest altitudes transects are displayed on most right-hand side. One longitudinal degree corresponds to $\sim 111 \mathrm{~km}$.

$\mathrm{CO}$ mixing ratios during the transport downwind of the urban emission source on short time scales (hours). All plume components $\left(\mathrm{CO}, \mathrm{O}_{3}\right.$ and $\left.\mathrm{NO}_{\mathrm{x}}\right)$ are expected to be equally affected by plume dispersion in the boundary layer; and deviations in the ratios between reactive and long-lived gases will give insight into the role of their chemical processing (production or conversion/degradation, respectively), hence eliminating the dilution effects.

Here, the enhancement factor $\left(\mathrm{EF}_{\mathrm{O}_{3} / \mathrm{CO}}\right)$ is calculated as the enhancement $(\Delta)$ of $\mathrm{O}_{3}$ in the plume $\left(\mathrm{O}_{3} p\right)$ above the respective background values $\left(\mathrm{O}_{3} b\right.$, derived from the edges of the flight transects at either side of the plume) over the enhancement of the conserved tracer $\mathrm{CO}$ : 
$\mathrm{EF}_{\mathrm{O}_{3} / \mathrm{CO}}=\frac{\Delta \mathrm{O}_{3}}{\Delta \mathrm{CO}}=\frac{\mathrm{O}_{3} p-\mathrm{O}_{3} b}{\mathrm{CO} p-\mathrm{CO} b}$

Figure 7 shows the mean enhancement factors as a function of downwind distance from Manaus City or the plume photochemical age, respectively. The data at $10 \mathrm{~km}$ distance, with highly elevated $\mathrm{CO}$ but relatively low $\mathrm{O}_{3}$, had the least significant correlation. This can be explained by a fresh pollution plume not yet having realized its $\mathrm{O}_{3}$ production potential (see below). A linear regression using the reduced-major-axis (RMA) regression algorithm (Cantrell, 2008) gives increasing slopes between 0.18 (10 km distance) to $1.25(100 \mathrm{~km}$ distance) indicating an enhancement of $\mathrm{O}_{3}$ exceeding a factor of 5, which compares reasonably well to the lower bound estimate neglecting dilution effects presented above.

These $\mathrm{O}_{3}$ production rates were greater than the values observed almost exactly 16 years earlier (on 29 July 1985) in the Manaus plume during ABLE-2A (Andreae et al., 1988). During that campaign, the aircraft encountered the plume at about $3^{\circ} 15^{\prime} \mathrm{S}$ to $3^{\circ} 30^{\prime} \mathrm{S}$, and $60^{\circ} 44^{\prime} \mathrm{W}$ to $61^{\circ} 01^{\prime} \mathrm{W}$, at an altitude of 500 feet, and a distance of about $100 \mathrm{~km}$ from Manaus. The wind speed was about $6.4 \mathrm{~m} \mathrm{~s}^{-1}$, and the plume age about $4 \mathrm{~h}$. The $\mathrm{O}_{3}$ and $\mathrm{CO}$ maxima were 35.6 and $159 \mathrm{ppb}$, background was 17 and $115 \mathrm{ppb}$, corresponding to a $\Delta \mathrm{O}_{3} / \Delta \mathrm{CO}$ of 0.47 and an $\mathrm{O}_{3}$ production rate of about $4.3 \mathrm{ppb} \mathrm{h}^{-1}$. The NO mixing ratio in the plume reached only about 80 ppt. Considering the rapid growth and industrialization of Manaus between the two campaigns, it is likely that the increased $\mathrm{NO}$ and $\mathrm{O}_{3}$ concentrations in 2001 reflect increasing emissions from power generation and other human activities.

Ozone production in the Manaus plume is considerably more efficient than in biomass burning plumes. In the Amazon, Andreae et al. (1988) found that $\Delta \mathrm{O}_{3} / \Delta \mathrm{CO}$ in young biomass smoke plumes was 0.01 to 0.09 , and Mauzerall et al. (1998) reported a range of 0.15 to 0.74 for fresh to old plumes during TRACE-A. Highly aged plumes ( $>10$ days) from Africa gave 0.2-0.7 (Andreae et al., 1994 [CITE-3]). In smoke plumes over Africa, values of about 0.10 were reached after 1-2 h (Jost et al., 2003; Trentmann et al., 2005; Yokelson et al., 2003).

\subsection{Urban versus power plant plume}

Figure 8 shows a time series of trace constituents from Flight \#11 (including $\mathrm{NO}_{2}$ ), along a cross-plume (north-south) transect located $10 \mathrm{~km}$ downwind distance of Manaus. Peak values of $\mathrm{NO}_{\mathrm{x}}$ (blue symbols in Fig. 8) showed a spatial offset to the south relative to the $\mathrm{CO}$ peak mixing ratios (black line in Fig. 8) with the $\mathrm{NO}_{\mathrm{x}} / \mathrm{CO}$ ratio being much higher in the southern part of the plume. This phenomenon observed close to Manaus is thought to reflect the influence of the power plants agglomerated in the south of the city (see yellow pins in Fig. 1). Indeed, back-trajectories from the location of the $\mathrm{NO}_{\mathrm{x}}$ peak pass almost directly over the power plant sites. This is further supported by a much higher $\Delta \mathrm{CO} / \Delta \mathrm{CO}_{2}$ ra-

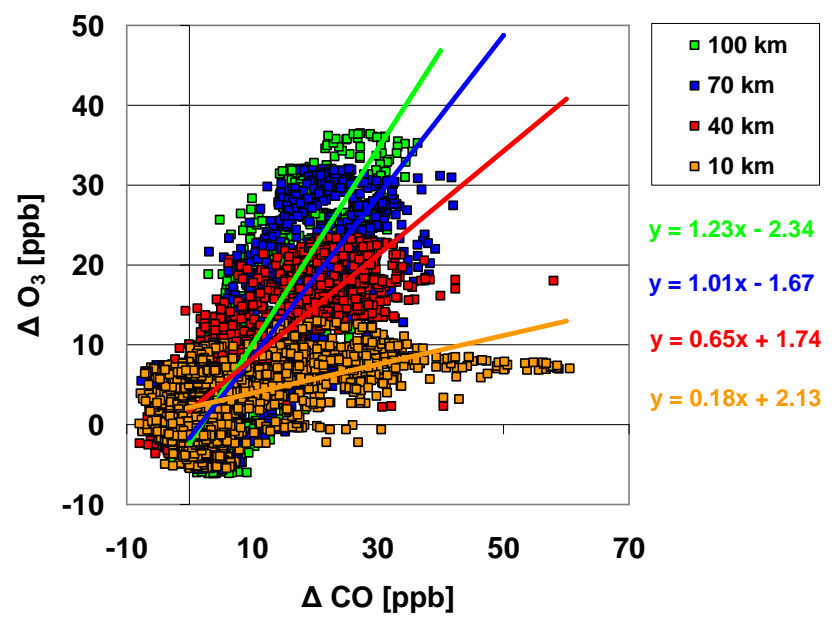

Fig. 7. $\Delta \mathrm{O}_{3}$ to $\Delta \mathrm{CO}$ enhancement factors as a function of downwind distance from Manaus City during Flight \#18 on 19 July 2001, 10:00-14:00 LT. Data from all transects of each vertical profile are binned. Slopes of a linear regression using the reduced-major-axis (RMA) regression method are given.

tio in the northern part of the plume (F11-1N in Table 2) than in its southern part (F11-1S).

In general, urban and power plant plumes have contrasting chemical characteristics (Joos et al., 1990; Duncan et al., 1995). This is because an urban plume is sufficiently diluted to allow active photochemistry to occur even in the source region. On the other hand, fossil fuel power plants are a major source of $\mathrm{NO}_{\mathrm{x}}$ (Trainer et al., 1995), with very high $\mathrm{NO}_{\mathrm{x}} / \mathrm{CO}$ ratios and a high load of particles (especially small $\mathrm{CN}$ ), these all being dependent on the fuel and combustion efficiency (see EPA AP-42). Because power plant combustion processes are finely tuned to extract energy from their fuel, they emit only minor amounts of VOCs that can serve as precursors for $\mathrm{O}_{3}$ production. Consequently, power plant plumes also have a high $\mathrm{NO}_{\mathrm{x}} / \mathrm{VOC}$ ratio (Nunnermacker et al., 2000) and $\mathrm{O}_{3}$ formation in the chemical regime of such plumes does not occur until there is sufficient dilution of the initially high $\mathrm{NO}_{\mathrm{x}}$ conditions and mixing with VOCs from background air masses. For example, studies by Ryerson et al. (1998) and Frost et al. (2006) showed for different US power plant plumes that the formation of ozone from a small amount of larger point sources is considerably slower compared to plumes from a respectively high number of smaller sources. Approximately the same maximum ozone was observed, but the net ozone production efficiency was about a factor of three smaller for the larger power plant. Furthermore, larger combustors typically emit relatively less $\mathrm{CO}$ and VOC than small combustors. This is because smaller units usually have less high-temperature residence time, and therefore require less time to reach complete combustion compared to the larger combustors (EPA AP-42). For this reason, the application of a small number of large power plants 


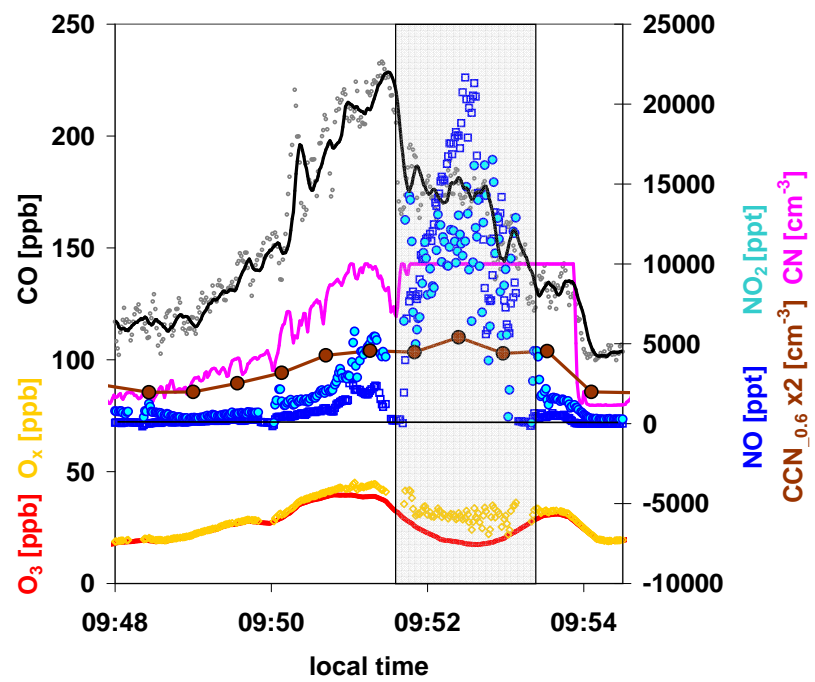

Fig. 8. Crosswind (north-south) urban plume transect (from Flight \#11, on 15 July 2001, 09:00-13:00 LT) observed at 410 m elevation, at $10 \mathrm{~km}$ distance from Manaus. The grey box indicates a high $\mathrm{NO}_{\mathrm{x}}$ regime, where $\mathrm{O}_{3}$ enhancement was depressed in the centre of the power plant plume. The $\mathrm{CN}$ instrument saturated in the power plant plume at concentrations $>10.000 \mathrm{~cm}^{-3}$.

in Manaus City, favouring $\mathrm{NO}_{\mathrm{x}}$ over $\mathrm{CO}$ and VOC emissions, was expected to result in reduced net ozone production in the near field of the city, but with ozone production spreading over larger distances in the far-field downwind over the forest. Generally speaking, a given decrease in $\mathrm{NO}_{\mathrm{x}}$ emissions at low-level $\mathrm{NO}_{\mathrm{x}}$ conditions reduces $\mathrm{O}_{3}$, while at higher $\mathrm{NO}_{\mathrm{x}}$ levels the same emission reduction results in a smaller $\mathrm{O}_{3}$ decrease or even an $\mathrm{O}_{3}$ increase. This behaviour is a direct consequence of the non-linear dependence of $\mathrm{O}_{3}$ on $\mathrm{NO}_{\mathrm{x}}$. Plumes that evolve in a regime with larger biogenic VOC background emissions, as in the case of Manaus, will remain in the ozone-producing regime at higher $\mathrm{NO}_{\mathrm{x}}$ levels compared to those plumes with low mixing ratios of reactive VOC (Frost et al., 2006).

During Flight $\# 11, \mathrm{NO}_{\mathrm{x}}$ mixing ratios were $>30 \mathrm{ppb}$ at $10 \mathrm{~km}$ distance of Manaus (NO $>20 \mathrm{ppb}$ and $\mathrm{NO}_{2}>10 \mathrm{ppb}$; Fig. 8). Chemical models indicate that the rate of $\mathrm{O}_{3}$ production increases linearly with increasing $\mathrm{NO}_{\mathrm{x}}$ mixing ratios in the low $\mathrm{NO}_{\mathrm{x}}$ range $\left(\mathrm{NO}_{\mathrm{x}}\right.$-limited regime). At higher $\mathrm{NO}_{\mathrm{x}}$ mixing ratios, models predict ozone production rates to decrease with increasing $\mathrm{NO}_{\mathrm{x}}$ $\left(\mathrm{NO}_{\mathrm{x}}\right.$-saturated). During the more stagnant meteorological conditions of Flight \#11, the very high $\mathrm{NO}_{\mathrm{x}}$ regime led to a depression of the $\mathrm{O}_{3}$ enhancement within the centre of the power plant plume (red line in Fig. 8). On one hand this might have been due to $\mathrm{O}_{3}$ titration by high mixing ratios of the primarily emitted $\mathrm{NO}\left(\mathrm{NO}+\mathrm{O}_{3} \rightarrow \mathrm{NO}_{2}\right)$, typically occurring in time scale of a few minutes within the city area. The impact of this effect can be evaluated by considering measured values of $\mathrm{O}_{\mathrm{x}}\left(=\right.$ sum of $\mathrm{O}_{3}$ and $\left.\mathrm{NO}_{2}\right)$, which accounts for the $\mathrm{O}_{3}$ depletion by the $\mathrm{NO}$ to $\mathrm{NO}_{2}$ conversion. But as shown in Fig. $8\left(\mathrm{O}_{\mathrm{x}}\right.$, yellow line $)$ only part of the reduced $\mathrm{O}_{3}$ enhancement can be explained by this effect. Alternatively, high mixing ratios of $\mathrm{NO}_{2}\left(\mathrm{NO}_{2}+\mathrm{OH}\right.$ $\rightarrow \mathrm{HNO}_{3}$ ) lead to competition for the $\mathrm{OH}$ radical needed for VOC oxidation and respective production of organic peroxides. This depletion of $\mathrm{OH}$ through $\mathrm{HNO}_{3}$ formation would result in decreased availability of peroxy radicals for the $\mathrm{O}_{3}$ production. Further evidence of a temporary $\mathrm{OH}$ depletion within the Manaus plume can be found in the low MVK/MACR ratios observed in the vicinity of Manaus, as is discussed below. The non-linearity (cease) of ozone production within the high- $\mathrm{NO}_{\mathrm{x}}$ conditions of the plume is in close agreement with Ryerson et al. (2001), who observed enhanced $\mathrm{O}_{3}$ production at $\mathrm{NO}_{\mathrm{x}}$ mixing ratios $<10 \mathrm{ppb}$ in the periphery of rural US coal-fired power plant plumes and $\mathrm{O}_{3}$ suppression at $\mathrm{NO}_{\mathrm{x}}$ mixing ratios $>15 \mathrm{ppb}$ in the core of the plume.

The concept of ozone production efficiency $\left(\mathrm{O}_{3} / \mathrm{NO}_{\mathrm{x}}\right.$; OPE) is defined as the number of ozone molecules produced per molecule of $\mathrm{NO}_{\mathrm{x}}$. In Flight \#11 three transects were flown at similar altitudes at 10, 40 and $70 \mathrm{~km}$ distance from Manaus; and a nearly constant $\mathrm{NO}_{2} / \mathrm{NO}$ ratio was found after a travel distance of $\sim 40 \mathrm{~km}\left(\mathrm{NO}_{2} / \mathrm{NO}\right.$ of 5.6 versus 5.3 for the $70 \mathrm{~km}$ travel distance), indicating that the $\mathrm{NO}_{\mathrm{x}}$ photodynamic equilibrium had been already been reached. Maximum $\mathrm{O}_{3}$ mixing ratios of $50 \mathrm{ppb}$ in $70 \mathrm{~km}$ distance were similar to the values at the same altitude and distance as during Flight \#18 (see Fig. 1). The ozone production efficiency was 53 (49) molecules $\mathrm{O}_{3}$ per molecule $\mathrm{NO}_{x}$ at $40(70) \mathrm{km}$ distance from Manaus (Fig. 9). Within a high biogenic VOC background regime, such as the tropical rainforest, the net $\mathrm{O}_{3}$ formation rates and yields per $\mathrm{NO}_{\mathrm{x}}$ molecule oxidized in plumes are substantially higher than observed in other urban and power plant plumes (see Chameides et al., 1988 for the Atlanta case, or Kleinman et al., 2002 for the Houston case, being exposed to very high anthropogenic VOC emissions).

\subsection{Isoprene oxidation pathways: change from Low- $\mathrm{NO}_{\mathrm{x}}$ to High-NO $\mathrm{N}_{\mathrm{x}}$ conditions}

Isoprene can play an important role in $\mathrm{O}_{3}$ formation in rural areas (Trainer et al., 1987), for cities (Chameides et al., 1988), and for power plant plumes (Luria et al., 2000; Ryerson et al., 2001). It is very reactive $(k \mathrm{OH}=$ $10.0 \pm 1.2 \times 10^{-11} \mathrm{~cm}^{3}$ molecule ${ }^{-1} \mathrm{~s}^{-1}$ at $294 \mathrm{~K}$; Karl et al., 2006) and thus even sub-ppb levels can dominate the overall OH-VOC reactivity. The chemistry of the polluted troposphere is considerably more complex than that for less polluted regions because of the presence of many different VOCs. For example, recent road tunnel measurements in São Paulo identified alkanes, aromatic compounds, alkenes and aldehydes as the main classes of anthropogenic VOCs from vehicles in Brazil (Martins et al., 2006). Although there were many anthropogenic VOCs present in the Manaus plume 


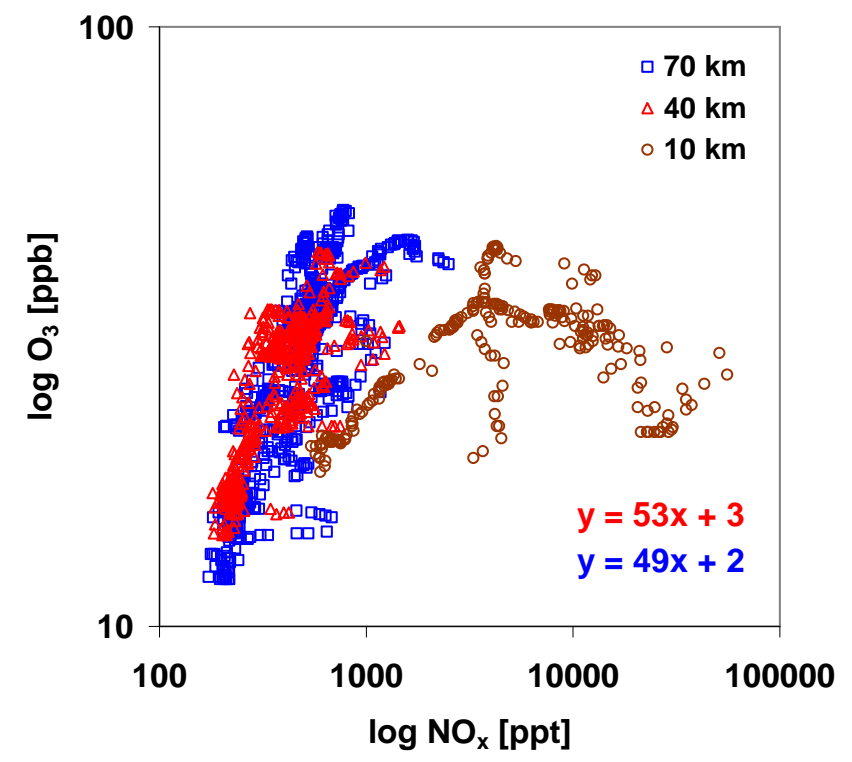

Fig. 9. Absolute values of $\mathrm{O}_{3}$ versus $\mathrm{NO}_{\mathrm{x}}$ during Flight \#11 (altitudes in the range of $230-280 \mathrm{~m}$, with respective high degree of short-term variability due to the proximity of these flight transects to the surface sources). High $\mathrm{NO}_{\mathrm{x}}$ mixing ratios observed in the centre of the plume at $10 \mathrm{~km}$ distance of Manaus were associated with low $\mathrm{O}_{3}$ enhancement (see Fig. 8). Slopes of a linear regression based on the reduced-major-axis (RMA, linear) regression method are given only for 40 and $70 \mathrm{~km}$ distance.

(mean toluene up to $500 \mathrm{ppt}$ and benzene up to $400 \mathrm{ppt}$, with high horizontal and vertical scatter), their OH-reactivityweighted total concentration was low compared to that of isoprene.

Isoprene mixing ratios, measured from the few VOC grab samples taken during the plume flight transects, are shown in Fig. 10. In general, isoprene is quickly removed in the tropical rainforest atmosphere due to its high reactivity towards $\mathrm{OH}$, and hence mixing ratios are dominated by local emissions. Although the vertical profiles revealed the expected decrease with height (see Fig. 3), due to reduced vegetation cover and thus lower emission rates from the urban area and the adjacent Rio Negro, the observed mixing ratios were low compared to the remote rainforest atmosphere. Only at $70 \mathrm{~km}$ distance of Manaus was a mixing ratio of $1.6 \mathrm{ppb}$ recovered at the lowermost sampling altitude $(100 \mathrm{~m})$. These low mixing ratios can be understood either by (i) reduced isoprene emissions (production) by the city/river surface and/or (ii) enhanced processing (destruction) of this reactive compound within the plume.

Under typical background conditions within the tropical boundary layer, isoprene chemical degradation is dominated by its reaction with $\mathrm{OH}$ with the contribution of isoprene ozonolysis (or reaction with the $\mathrm{NO}_{3}$ radical) estimated to account only for a minor fraction of about $1 \%$ during daytime in LBA-CLAIRE-2001 (Kuhn et al., 2007). The

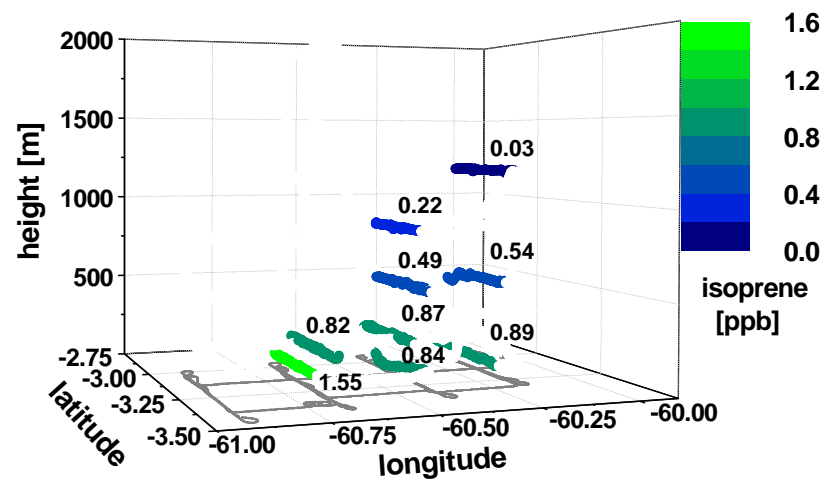

Fig. 10. 3-D image of isoprene mixing ratios observed downwind of Manaus City $\left(-3.08^{\circ},-60.01^{\circ}\right)$ during Flight \#18 on 19 July 2001 , 10:00-14:00 LT. One longitudinal degree corresponds to $\sim 111 \mathrm{~km}$.

$\mathrm{OH}$ adds to one of the double bonds of isoprene, forming alkyl radicals that in turn add $\mathrm{O}_{2}$ to form peroxy radicals $\left(\mathrm{RO}_{2}\right)$. The $\mathrm{RO}_{2}$ radicals then decompose by converting $\mathrm{NO}$ to $\mathrm{NO}_{2}$, with photodissociation of $\mathrm{NO}_{2}$ then leading to $\mathrm{O}_{3}$ formation (Eqs. 1-3). The isoprene degradation reaction yields the unsaturated $\mathrm{C} 4$ carbonyls methacrolein (MACR) and methylvinyl ketone (MVK) plus formaldehyde $\left(\mathrm{CH}_{2} \mathrm{O}\right)$. These carbonyls as well as formaldehyde have been found in high amounts within the tropical atmosphere (Kesselmeier et al., 2002), and also constituted a significant fraction of VOC in the Manaus plume during LBA-CLAIRE-2001.

The rate of isoprene oxidation by $\mathrm{OH}$ is also dependent on $\mathrm{NO}_{\mathrm{x}}$ mixing ratios in a non-linear way. Barket et al. (2004) found a crossover from $\mathrm{NO}_{\mathrm{x}}$-sensitive to VOC-sensitive conditions at $\sim 8 \mathrm{ppb}$ of $\mathrm{NO}_{\mathrm{x}}$ comparing four North American sites. At low $\mathrm{NO}_{\mathrm{x}}$ conditions, peroxy radicals terminate via self-reaction and reaction with $\mathrm{HO}_{2}$. At high $\mathrm{NO}_{\mathrm{x}}$ conditions, $\mathrm{OH}$ is consumed by the reaction with $\mathrm{NO}_{2}$ to form nitric acid, and is hence less available for peroxy radical production necessary for $\mathrm{O}_{3}$ formation.

In general, the production of $\mathrm{OH}$ radicals is at its maximum in the tropics, because the ingredients (UV radiation and water vapour) are all at a high levels. However, until recently, atmospheric chemistry and transport models tended to predict that high mixing ratios of isoprene observed in the lower part of the tropical atmospheric boundary layer should give rise to substantial reductions in $\mathrm{OH}$ radical concentrations, thus strongly reducing the atmospheric oxidation capacity under non-polluted conditions (e.g., Warneke et al., 2001; Lelieveld et al., 2004). Recent field studies in the remote Amazon Basin have, however, provided indirect evidence that isoprene has a considerably smaller effect on $\mathrm{OH}$ than previously thought (Kuhn et al., 2007; Karl et al., 2007). These first measurements have been confirmed through subsequent observations of a high $\mathrm{OH}$ burden in the boundary layer above tropical forest in Suriname, Guyana and French Guiana (Lelieveld et al., 2008). It thus seems that pathways of the degradation products of the isoprene- $\mathrm{OH}$ reaction are 
capable of recycling $\mathrm{OH}$ levels over tropical forest. Hence, in the absence of external anthropogenic influences, the forest maintains its high self-cleansing capacity of the atmosphere, necessary for removal of most gaseous pollutants. But where deforestation and anthropogenic emissions of NO intervene, photochemical air pollution and perturbation of the atmospheric chemistry become likely (Lelieveld et al., 2008).

Although there were no direct measurements of $\mathrm{OH}$ available for the LBA-CLAIRE-2001 campaign, its concentration can be inferred from the relative importance of the isoprene degradation pathways, i.e., from the ratio of the primary reaction products MVK and MACR (Kuhn et al., 2007; Karl et al., 2007). Oxidation of isoprene by $\mathrm{OH}$ in the presence of $\mathrm{NO}_{\mathrm{x}}$ produces MVK and MACR with yields of $32 \%$ and 23\%, respectively (Tuazon and Atkinson, 1990). Thus the ratio MVK/MACR would be $\sim 1.4$ if MVK and MACR were not to undergo further reaction. Oxidation by $\mathrm{OH}$, however, removes MACR more quickly than MVK and further increases the MVK/MACR ratio. In contrast, oxidation of isoprene by $\mathrm{O}_{3}$ yields more MACR than MVK, and MVK reacts more quickly with $\mathrm{O}_{3}$ than MACR. Thus ozone-dominated isoprene oxidation should result in MVK/MACR ratios lower than 0.4 (Carter and Atkinson, 1996). Tower-based as well as airborne measurements in remote background air during LBA-CLAIRE showed that the ratio MVK/MACR was close to 2 throughout the CBL. This is indicative of $\mathrm{OH}$-dominated isoprene degradation, with estimated mean $\mathrm{OH}$ concentrations of $5.5 \times 10^{6}$ molecules $\mathrm{cm}^{3}$ in the CBL (Kuhn et al., 2007). The MVK/MACR ratios found within the Manaus plume are shown in Fig. 11. In the vicinity of Manaus City $(10 \mathrm{~km})$, where $\mathrm{O}_{3}$ was not yet greatly enhanced compared to background conditions, the MVK/MACR ratios were considerably reduced (0.55-0.95), suggesting ozone-dominated isoprene oxidation thus being indicative of a net destruction of $\mathrm{OH}$ radicals within this urban chemical regime. This is in agreement, for example, with a study by Dommen et al. (2002), who showed that total peroxides (hydrogen peroxide and organic peroxides) in the Milan urban plume were depleted when $\mathrm{NO}_{\mathrm{x}}$ mixing ratios were above $10 \mathrm{ppb}$.

On the other hand, $\mathrm{OH}$ can be regenerated by the catalytic action of emitted $\mathrm{NO}_{\mathrm{x}}$ after dilution to values below this threshold. The recovery of $\mathrm{OH}$ within the observed travel distance is documented by the increase in the MVK/MACR ratios found further downwind of Manaus (Fig. 11). Several analyses of observations and model studies on $\mathrm{OH}$ radical chemistry have given conflicting results indicating that regional air pollution, combined with natural emissions of VOC, can either enhance or deplete hydroxyl. This may in part depend on the spatial scale of the calculations (Brasseur et al., 2003). Since this issue is important for the lifetime and transport of air pollutants throughout the globe, it is essential to reduce the uncertainties and perform coordinated experimental (by means of direct measurements) as well as further theoretical investigations on the oxidation capacity within urban plumes.

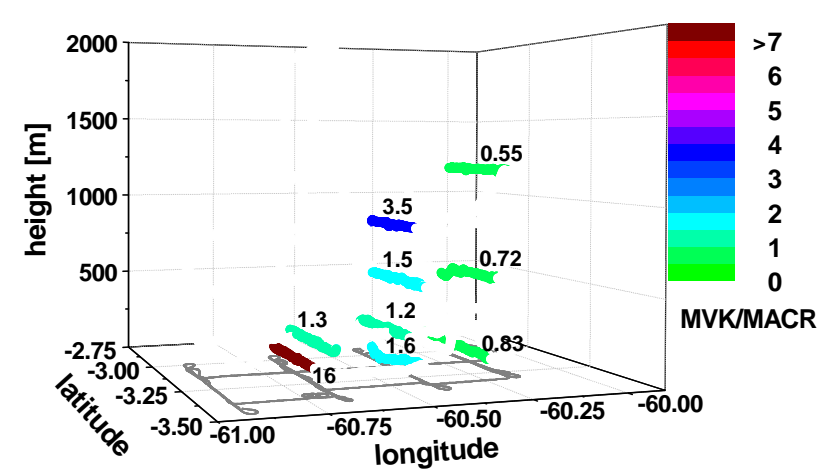

Fig. 11. 3-D image of the MVK/MACR ratios (GC-FID analysis) observed downwind of Manaus City $\left(-3.08^{\circ},-60.01^{\circ}\right)$ during Flight \#18 on 19 July 2001, 10:00-14:00 LT. Generally low ratios were also confirmed by the GC-MS analysis (data not shown). One longitudinal degree corresponds to $\sim 111 \mathrm{~km}$.

\subsection{Aerosols in the Manaus plume}

Aerosol particles affect ozone and $\mathrm{OH}$ production directly by providing surfaces for heterogeneous reactions, and also have a strong impact on the atmospheric radiation field in and around urban plumes. The radiative impact depends strongly on the aerosol optical properties, with important consequences for the photochemical oxidant production within the plume. High loads of $\mathrm{CCN}$-active aerosols also cause the formation of an increased number of small droplets for a given amount of cloud water, and these smaller droplets will not coalesce efficiently to form precipitation drops. Clouds with high droplet number concentration must develop up to very high altitudes in order to precipitate, requiring ice formation for the initiation of rain production (Andreae et al., 2002; Rosenfeld et al., 2002, 2008). Furthermore, absorption and scattering of sunlight causes the ground to cool and the polluted layers to heat up. This stabilizes the lower troposphere, which can then further inhibit the formation of new clouds. On the other hand, the release of latent heat to higher levels in the troposphere can invigorate convection, with the increased amount of ice phase increasing lightning production (Koren et al., 2004; Andreae et al., 2004). Taken together, these processes have substantial effects for the redistribution of energy as well as chemical species in the tropical atmosphere - potentially reaching far beyond the tropics (Graf et al., 2001; Nober et al., 2003).

On Flight \#18, as well as on all other flights where the Manaus plume was sampled, the peak total aerosol number concentrations $(\mathrm{CN})$ in the plume transects reached around 25000 to 30000 particles per $\mathrm{cm}^{-3}$. $\mathrm{CCN}_{0.6}$ were also enhanced with respect to background conditions, with peak values of about one order of magnitude below the peak $\mathrm{CN}$ concentrations $\left(2500-4000 \mathrm{~cm}^{-3}\right)$. The $\mathrm{CN}$ concentrations in the Manaus plume were similar to those in the New York plume (Brock et al., 2008) and the Houston plume (A. Nenes, personal communications, 2007). The highest aerosol levels 
usually coincided with the peak values of $\mathrm{NO}_{\mathrm{x}}$, which indicates a strong influence of the power plants in the south of Manaus on $\mathrm{CCN}_{0.6}$ (Fig. 8). Enhancement factors were obtained from correlation slopes (RMA) of the various parameters of interest against the tracers $\mathrm{CO}$ and $\mathrm{CN}$, to eliminate the effects of plume dispersion and dilution.

The $\Delta \mathrm{CN} / \Delta \mathrm{CO}$ ratios in the plume were in the range of about $100-900 \mathrm{~cm}^{-3} \mathrm{ppb}^{-1}$, with an average of $340 \pm 230$ (Table 2). This is about an order of magnitude higher than that observed in biomass burning plumes during this campaign $\left(50 \pm 9 \mathrm{~cm}^{-3} \mathrm{ppb}^{-1}\right.$; Table 2$)$ and reported by Guyon et al. (2005) from another Amazon flight campaign. They are also considerably higher than the ratios observed in urban plumes in the northeastern US, e.g., the New York City plume (ca. $80 \mathrm{~cm}^{-3} \mathrm{ppb}^{-1}$ about $60 \mathrm{~km}$ downwind of the city; Brock et al., 2008).

The highest ratios were found where the plumes could be linked by back-trajectories to the power plants (e.g., transects F06-2, F11-1S, and F18-1 in Table 2). For example, the air containing the peak $\mathrm{CN}$ concentrations on transect F18-1 was found to have passed over the two power plant sites about 45 and $90 \mathrm{~min}$, respectively, before sampling. Flight \#11 allowed side-by-side sampling of the urban and power plant plumes, as discussed above. The part of the plume which contained fresh power plant emissions had five times higher $\Delta \mathrm{CN} / \Delta \mathrm{CO}$ ratios than the urban plume (as calculated from only a small subset of F11 data, and from other flights with a complete $\mathrm{CN}$ data range). At short distances from Manaus, $\mathrm{CN}$ inputs are thus a mixture of power plant emissions with $\Delta \mathrm{CN} / \Delta \mathrm{CO}$ values of up to $900 \mathrm{~cm}^{-3} \mathrm{ppb}^{-1}$, and urban emissions with $\Delta \mathrm{CN} / \Delta \mathrm{CO}$ values of $100-300 \mathrm{~cm}^{-3} \mathrm{ppb}^{-1}$, with some pyrogenic aerosols also present with much lower $\Delta \mathrm{CN} / \Delta \mathrm{CO}$.

The pollution particles in the plume were not very efficient light scatterers. In contrast to the background aerosol, which had a ratio $\Delta \sigma_{\mathrm{sp}} / \Delta \mathrm{CN}$ of $4.5 \pm 3.1 \times 10^{-3}$ (at $550 \mathrm{~nm}$ ), the mean ratio in the plumes was only $0.93 \pm 0.82 \times 10^{-3}$. Pyrogenic emissions had a value of $3.6 \pm 2.0 \times 10^{-3}$, close to that of boundary layer aerosol. This low scattering efficiency of the plume aerosols suggests that they were much smaller than the biomass burning smoke and boundary layer particles, a conclusion consistent with their poor $\mathrm{CCN}_{0.6}$ efficiency as discussed below. In contrast to the pronounced differences in the $\mathrm{CN}$-normalized data, the ratio $\Delta \sigma_{\mathrm{sp}} / \Delta \mathrm{CO}$ was not very different between the Manaus plume $(0.25 \pm 0.16)$ and the biomass smoke plumes $(0.33 \pm 0.25)$. Both values are similar to the ratio from biomass smoke obtained during SMOCC-2002 (0.38 \pm 0.02 ; Chand et al., 2006). This suggests that much of the $\mathrm{CO}$ and the larger, more scattering particles in the Manaus plume were from activities such as residential burning, whereas the power plants (emitting $\mathrm{SO}_{2}$ rapidly forming sulphuric acid particles) were responsible for the production of a large number of very small, weakly scattering particles, and with only a relatively small contribution of CO.
Like the background aerosol, where a very large fraction of the total particle number were able to act as $\mathrm{CCN}(0.66 \pm 0.15$ at $0.6 \%$ supersaturation), the pyrogenic aerosols sampled during LBA-CLAIRE-2001 were also efficient $\mathrm{CCN}$, with a mean $\triangle \mathrm{CCN}_{0.6} / \triangle \mathrm{CN}$ of $0.62 \pm 0.11$. This is in close agreement with the results from smoke aerosols obtained during SMOCC-2002 (Vestin et al., 2007). By contrast, $\Delta \mathrm{CCN}_{0.6} / \Delta \mathrm{CN}$ ratios within the Manaus plume were much lower, averaging $0.16 \pm 0.12$. In the particlerich plumes from the power plants $\Delta \mathrm{CCN}_{0.6} / \Delta \mathrm{CN}$ were even lower, decreasing down to 0.03 (Table 2). The low CCN efficiency of the Manaus aerosols is likely attributable to the small particle size associated with urban pollution as suggested by the low scattering efficiency and high $\mathrm{CN}$ concentrations ( $\sim 10 \mathrm{~nm}$ D50 cutoff). Similar observations were made during the TexAQS II study in the Houston region, where the urban plume showed low CCN activity (ca. 0.06 at $\mathrm{SS}=0.15 \%$ ) with power plant plumes having no detectable CCN (A. Nenes, personal communication, 2007). In that study also, the authors were able to explain the low CCN efficiency of the fresh urban and power plant aerosol by their small size, rather than by differences in composition. In order not to be $\mathrm{CCN}$-active at a supersaturation of $0.6 \%$, particles would have had to be smaller than ca. $40 \mathrm{~nm}$ for pure sulphates or smaller than ca. $75 \mathrm{~nm}$ for pure secondary organic aerosols (Roberts et al., 2002; Petters and Kreidenweis, 2007). Formation of particles in this size range has been shown to occur in many urban environments, both from vehicle exhaust and from photochemical oxidation of $\mathrm{SO}_{2}$ (e.g., Dunn et al., 2004; Zhang et al., 2004; Wehner et al., 2008). In the Mexico City region, Kleinman et al. (2009) found that a prominent mode centred around $35 \mathrm{~nm}$ diameter dominated the aerosol size distribution in the least aged urban airmasses. The low pre-existent aerosol surface area in the clean Amazon atmosphere would facilitate nucleation and new particle formation (McMurry et al., 2005).

In spite of the considerable variability in $\Delta \mathrm{CN} / \Delta \mathrm{CO}$ values, almost all flights showed a similar decreasing trend in the $\Delta \mathrm{CN} / \Delta \mathrm{CO}$ ratio with distance and plume age, suggesting some particle number loss by coagulation processes (Jacobson and Seinfeld, 2004). This is illustrated in Fig. 12 for flights F\#09 and F\#18, which sampled preferentially the urban and power plant plumes, respectively. The observed decrease also shows that there was no significant new particle formation occurring in the plumes during the period under investigation, i.e., the time span between $\sim 1$ to $\sim 12 \mathrm{~h}$ after the airmass left the urban area.

On the other hand, while the number concentrations of particles were declining, a growth in particle size is suggested by the trends in scattering coefficients and $\mathrm{CCN}_{0.6} / \mathrm{CN}$ ratios with increasing distance from Manaus City. In spite of the considerable variability inherent in the data, probably resulting from the internal inhomogeneity of the plume, all flights showed increasing light scattering and $\mathrm{CCN}_{0.6}$ concentrations (normalized to $\mathrm{CO}$ or $\mathrm{CN}$ ), with increasing distance 


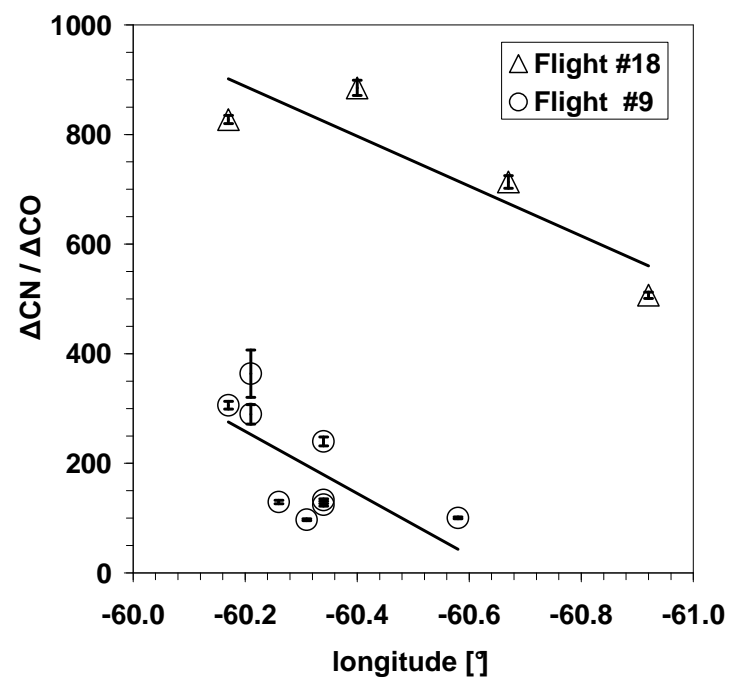

Fig. 12. $\Delta \mathrm{CN} / \Delta \mathrm{CO}$ ratios as a function of longitude from Manaus City $\left(-3.08^{\circ},-60.01^{\circ}\right)$ during Flight \#9 and \#18. One longitudinal degree corresponds to $\sim 111 \mathrm{~km}$.

from the city (Fig. 13). This growth in scattering shows that the total mass of the particles must have been increasing, whilst the increase of $\mathrm{CCN}_{0.6}$ activity is evidence for an increase in the mass of soluble matter. Together, these observations could be explained by simultaneous loss of some Aitken particles by coagulation, and condensational growth of Aitken particles into the optically and $\mathrm{CCN}$-active size range in a manner similar to processes already documented for Mexico City by Kleinman et al. (2009).

Particle growth by condensation is generally faster than coagulation in urban environments (Pandis et al., 1995). This growth is primarily by condensation of inorganic material, such as $\mathrm{H}_{2} \mathrm{SO}_{4}$, or oxidation products of organic precursors. In the power plant plumes, sulphuric acid formation was most likely the dominant process. In the urban plume, on the other hand, secondary organic aerosols (SOA) production is likely to have played a role. Model calculations suggest that under clean conditions, such as those that prevail over the Amazon Basin during the wet season, the transformation of organic precursors to SOA occurs at a very low yield (e.g., Kanakidou et al., 2000). Within pollution plumes, an amplifier effect is assumed to take place, where the yield of SOA increases sharply due to increased mixing ratios of $\mathrm{O}_{3}$, $\mathrm{OH}$ and pre-existing anthropogenic aerosol. Although anthropogenic VOC (most notably aromatic compounds) are believed to globally make a minor contribution to SOA (Tsigaridis and Kanakidou, 2003), they may be dominant in urban plumes (e.g., de Gouw et al., 2008; Volkamer et al., 2006; Kleinman et al., 2009). In addition, the injection of urban emissions into airmasses rich in biogenic VOC may dramatically enhance regional SOA formation from biogenic VOC (Goldstein et al., 2009).

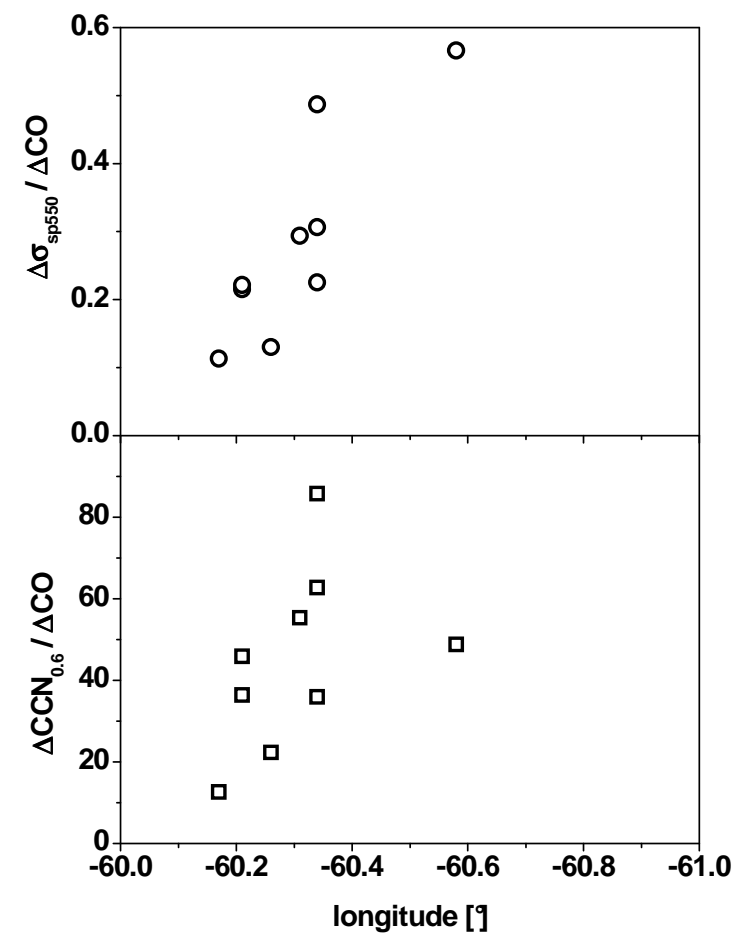

Fig. 13. Light scattering coefficients $\left(\Delta \sigma_{\mathrm{sp}} / \Delta \mathrm{CO}\right)$ and $\mathrm{CCN}_{0.6}$ activity ( $\triangle \mathrm{CCN}_{0.6} / \triangle \mathrm{CO}$ ) normalized to $\mathrm{CO}$ mixing ratios, as a function of downwind distance (longitude) from Manaus City $\left(-3.08^{\circ}\right.$, $-60.01^{\circ}$ ) during Flight \#9. One longitudinal degree corresponds to $\sim 111 \mathrm{~km}$.

Isoprene may contribute to SOA production via a number of heterogeneous chemical reactions, involving either polymerization or oxidation of isoprene and further reaction of its first-generation oxidation products (Kroll et al., 2006; Ng et al., 2007). Nevertheless, a detailed understanding of the chemical reaction pathways leading to the production of SOA from isoprene is currently lacking. Matsunaga et al. $(2003,2004)$ found high concentrations of second-generation isoprene oxidation products in aerosol samples, but the rates and products of the oxidation reactions of many of these first-generation products are poorly constrained (Surratt et al., 2006). Furthermore, it has been established recently that $\mathrm{NO}_{\mathrm{x}}$ levels exert a major influence on SOA formation (Kroll et al., 2006; Presto et al., 2005; Song et al., 2005; Ng et al., 2007). For photooxidation of isoprene, SOA yields have been shown to decrease substantially as the $\mathrm{NO}_{\mathrm{x}}$ level increases, due to the differences in peroxy radical chemistry (Kroll et al., 2006, and references therein). High mixing ratios of $\mathrm{NO}$ appeared to suppress the formation of SOA by suppressing hydroperoxide and $\mathrm{RO}_{2}$ formation (Kroll et al., 2006). On the other hand, Edney et al. (2005) showed that, in the presence of $\mathrm{SO}_{2}$, isoprene oxidation forms SOA even in the presence of high NO mixing ratios, suggesting that enhanced reactive uptake by acidic 
aerosol particles may counteract the reduced production of condensable species at high $\mathrm{NO}_{\mathrm{x}}$. On the other hand, it should be noted that Molina et al. (2004) provided experimental evidence that the reaction of gas-phase $\mathrm{OH}$ radicals with condensed organics may lead to efficient volatilization of organic compounds, thereby serving as a sink for SOA in the troposphere; an observation also supported by Kroll et al. $(2005,2006)$ who showed aerosol mass and volume to decrease rapidly at low to intermediate $\mathrm{NO}_{\mathrm{x}}$ levels.

For the Manaus plume case, the details of the mechanisms of SOA development from the oxidation of isoprene and terpenes have still to be evaluated. The relatively weak enhancement of the $\mathrm{CCN}_{0.6} / \mathrm{CN}$ ratio may reflect a high $\mathrm{NO}_{\mathrm{x}}$ scenario as shown by Kroll et al. (2006). The observed decrease in the MVK/MACR ratios suggests that the plume was depleted of radicals at least in close vicinity of the city (see above), which may confer one reasonable explanation why only a slow conversion from $\mathrm{CN}$ to $\mathrm{CNN}_{0.6}$ within the observed travel distance of the plume was found. With recovery of $\mathrm{OH}$ further downwind, this scenario may change. Further investigations, extending the range of observations further downwind and using a more complete set of instrumentation would be required to resolve these questions.

\subsection{SCM model results and sensitivity to precursor abatement strategies}

Atmospheric ozone production over an urban centre involves different stages, from being VOC-sensitive near the source(s) to being $\mathrm{NO}_{\mathrm{x}}$-sensitive further downwind; i.e., $P\left(\mathrm{O}_{3}\right)$ being either more sensitive to a small fractional change in VOC mixing ratios or to a small fractional change in $\mathrm{NO}_{\mathrm{x}}$ mixing ratios (e.g., 2000; Sillman, 1999). Fresh emissions of $\mathrm{NO}_{\mathrm{x}}$ are primarily $(>90 \%)$ emitted as $\mathrm{NO}$, leading to titration (degradation) of background ozone in the vicinity of the source. In the course of plume dilution a photostationary state will be reached between $\mathrm{NO}, \mathrm{NO}_{2}$ and $\mathrm{O}_{3}$ within minutes. High mixing ratios of $\mathrm{NO}_{2}\left(\mathrm{NO}_{\mathrm{x}}\right.$-saturated) in the fresh plume will act as $(\mathrm{OH})$ radical scavenger, suppressing VOC oxidation. Consequently, the production of nitric acid $\left(\mathrm{HNO}_{3}\right)$ is much higher than the production of organic peroxides, and net ozone production is linked to the consumption of VOC. An increase in VOC emissions then leads to an increase in peroxy radicals that convert $\mathrm{NO}$ to $\mathrm{NO}_{2}$, ultimately causing an increase in $\mathrm{O}_{3}$ (VOC-sensitive ozone production). In the $\mathrm{NO}_{\mathrm{x}}$-saturated stage, an increase of $\mathrm{NO}_{\mathrm{x}}$ emissions would scavenge even more radicals, diminishing the oxidizing capacity and hence net $\mathrm{O}_{3}$ production of the air parcel. During chemical aging of the plume further downwind, $\mathrm{NO}_{\mathrm{x}}$ levels decrease due to dilution, deposition and the chemical production of $\mathrm{HNO}_{3}$ and/or PAN, ultimately reaching a threshold where availability of $\mathrm{NO}_{2}$ poses a limitation for ozone production $\left(\mathrm{NO}_{\mathrm{x}}\right.$-sensitive). OH radicals then predominantly react with VOC instead of $\mathrm{NO}_{\mathrm{x}}$, generating organic peroxides. As a consequence the production of
$\mathrm{HNO}_{3}$ is reduced and a higher share of $\mathrm{NO}_{\mathrm{x}}$ may participate in the catalytic ozone production cycle, with organic peroxides being the major contributor to recycle $\mathrm{NO}_{2}$ (from NO) for ozone production. In this last stage, variations in VOC have little effects on ozone production and peroxy radicals are removed at relatively low rates mainly via recombination reactions.

In order to study these transitions in the chemical regime in terms of $\mathrm{NO}_{\mathrm{x}}$ and VOC limitations on ozone production in and outside the Manaus plume, we have applied a Single Column chemistry and meteorological Model (SCM). The SCM considers explicitly atmospheric chemistry processes, including anthropogenic and natural emissions, gasphase chemistry, wet and dry deposition and turbulent and convective tracer transport as a function of meteorological and hydrological drivers, surface cover, and land use properties. One feature of the SCM is that it allows analysis of the response of the meteorology and atmospheric chemistry to changes in surface cover by advecting the column along a prescribed transect (Ganzeveld and Lelieveld, 2004; Ganzeveld et al., 2008). Here we study the atmospheric column processes moving westward from $58^{\circ} \mathrm{W}$, $2.6^{\circ} \mathrm{S}$, northeast of Manaus, to $76^{\circ} \mathrm{W}, 6.8^{\circ} \mathrm{S}$, in three days (60 s timesteps), starting the simulations on 5 July 2001 at 03:00 LT. This implies that the city limit of Manaus was reached $\sim 10: 30$ LT, i.e., shortly after takeoff time for Flight \#18 (see white/blue straight line in Fig. 1). The residence time of the column over the city of Manaus is about $30 \mathrm{~min}$, i.e., the urban exchange regime is resolved for 30 grid points. For the urban tile grids we have modified the surface cover properties, which are generally inferred from a ecosystem database and satellite observations, by prescribing surface roughness at $2 \mathrm{~m}$, assuming a small vegetation cover of 0.2 , using a city area albedo of 0.1 and assuming reduced evapotranspiration (through a reduction of soil moisture limiting transpiration). We have also considered the impact of the river Rio Negro west of Manaus on the meteorology (and chemistry) directly downwind from Manaus, which extends over a distance of $\sim 12 \mathrm{~km}$. Most of the analysis presented here focuses on the development of the plume in the vicinity of Manaus with the daytime simulations for the first day, 5 July 2001, covering the domain of the observations. However, in order to assess the potential impact of the plume on the tropical forest further downwind, we also discuss some results on nitrogen and ozone deposition for 6-7 July. More details about the SCM are given by Ganzeveld et al. (2002, 2004, 2008).

For Manaus, detailed information from area sourcespecific emission categories is unfortunately not available. Consequently, a number of sensitivity simulations have been conducted with the SCM, to infer the emissions based on the observed $\mathrm{NO}_{\mathrm{x}}, \mathrm{CO}$, and speciated VOC concentrations observed 10-100 km downwind of Manaus during the LBACLAIRE-2001 campaign. Because of the two distinctly different chemical regimes found in the Manaus plume (Fig. 8), 

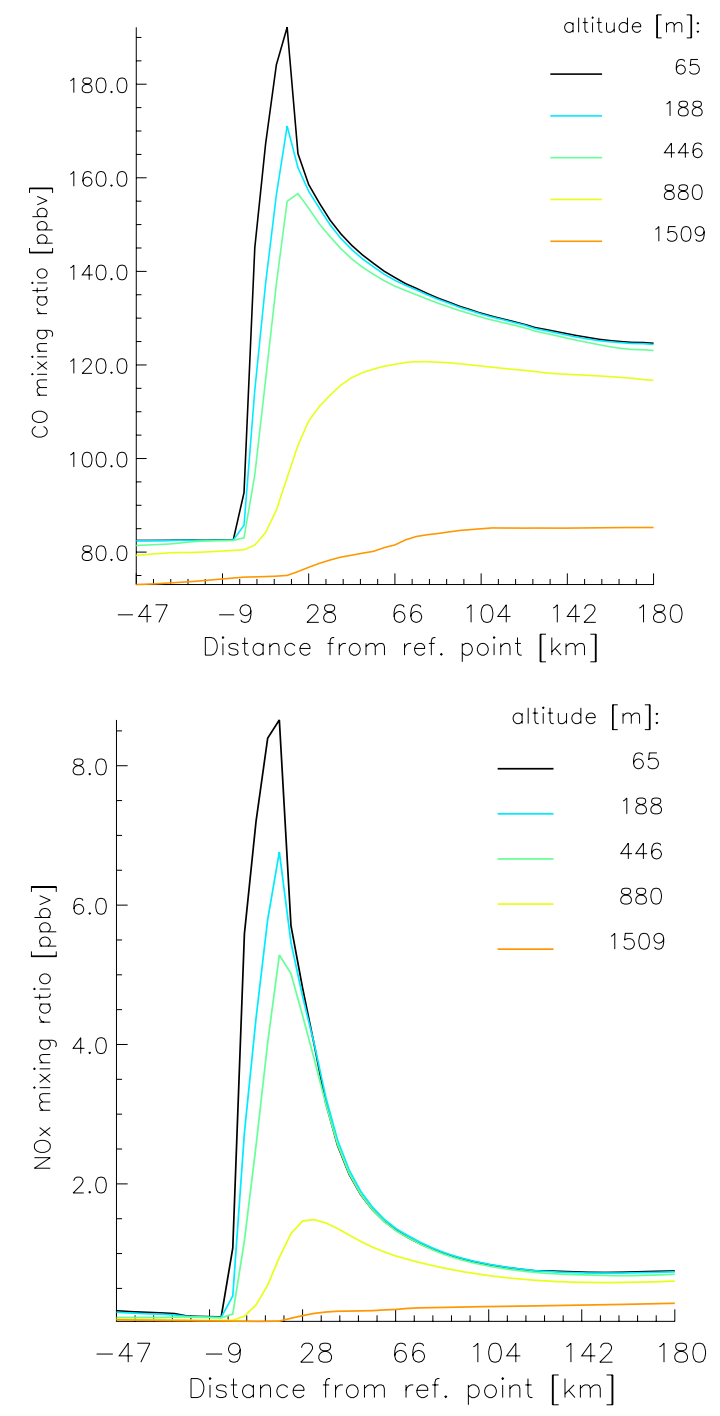

Fig. 14. Simulated $\mathrm{CO}$ (a) and $\mathrm{NO}_{\mathrm{x}}$ (b) mixing ratios for the 5 model layers that represent the convective boundary layer as a function of the distance relative to the eastern city limits, with a positive value indicating the distance downwind.

simulations have been conducted to infer the emission characteristics of the northern "urban" plume with enhanced $\mathrm{CO}$ to $\mathrm{NO}_{\mathrm{x}}$ mixing ratios, versus the southern "power plant" plume with enhanced $\mathrm{NO}_{\mathrm{x}}$ to $\mathrm{CO}$ mixing ratios. One initial experiment used, as a proxy for the Manaus city emissions, the $\mathrm{CO}$ and $\mathrm{NO}_{\mathrm{x}}$ anthropogenic emission fluxes from the EDGAR 3.2 fast track 2000 emission database (Van Aardenne et al., 2005) for the $1^{\circ} \times 1^{\circ}$ grid point that resembles the location of the city of São Paulo. Since this city covers about $1 / 7$ of the surface area of the $1^{\circ} \times 1^{\circ}$ grid point, the $1^{\circ} \times 1^{\circ}$ grid point emission fluxes were increased by a factor 7 based on the assumption that all the anthropogenic emissions in this grid point come from the city of São Paulo.

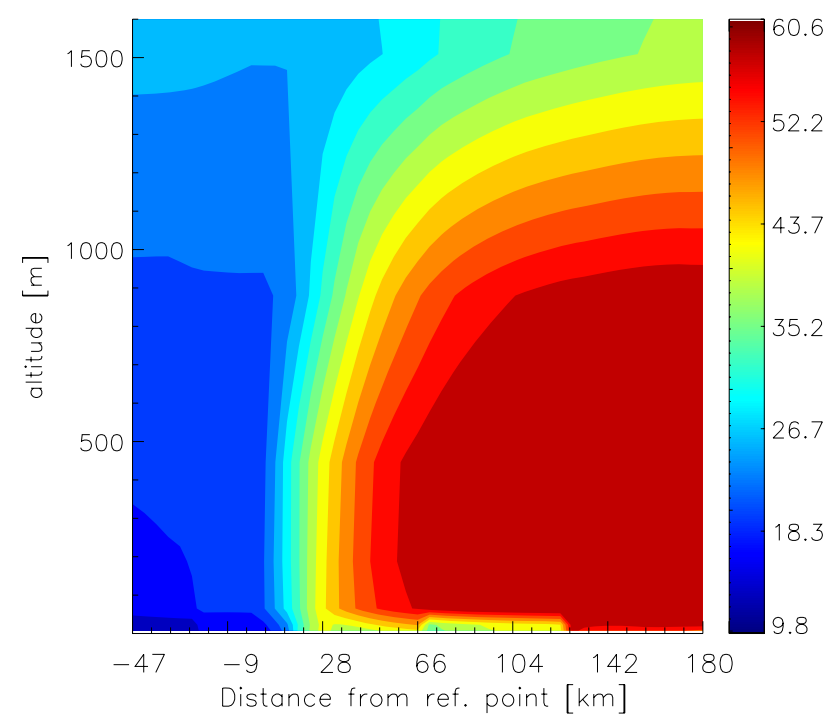

Fig. 15. Simulated $\mathrm{O}_{3}$ mixing ratio up to $1600 \mathrm{~m}$ altitude as a function of the distance relative to the eastern city limits, with a positive value indicating the distance downwind. The simulated convective boundary layer depth reaches a maximum of about $1500 \mathrm{~m}$.

The diagnostic convective boundary layer depth reaches a maximum of up to $\sim 1500 \mathrm{~m}$ above Manaus, associated with a simulated large sensible heat flux for the small vegetation cover and suppressed evapotranspiration. Figure 14 shows the simulated $\mathrm{CO}$ and $\mathrm{NO}_{\mathrm{x}}$ mixing ratios from 09:00 LT until 17:00 LT for the five model layers that represent the vertical maximum extent of the CBL. The mixing ratios are shown as a function of the distance relative to the eastern city limits (i.e., the river shore), with a positive value denoting distance downwind. The output frequency in this and all the following figures was $10 \mathrm{~min}$. It can be inferred from Fig. 14 that the model simulates $\mathrm{CO}$ and $\mathrm{NO}_{\mathrm{x}}$ mixing ratios at about $400 \mathrm{~m}$ altitude $10 \mathrm{~km}$ downwind of about $140 \mathrm{ppb} \mathrm{CO}$ and $4 \mathrm{ppb}$ $\mathrm{NO}_{\mathrm{x}}$, which appear to be at the lower range of the corresponding Manaus plume average observations (Fig. 8). Underestimation of the $\mathrm{CO}$ mixing ratios cannot be explained by low background $\mathrm{CO}$ mixing ratios as upwind $\mathrm{CO}$ mixing ratios of $80 \mathrm{ppb}$ in the SCM compare well with the observations at the K34 tower north of Manaus (Fig. 3). This is also the case for ozone where the model simulates upwind mixing ratios of $\sim 20 \mathrm{ppb}$. Figure 15 shows that the urban plume results in a simulated increase in ozone throughout the CBL up to $>50 \mathrm{ppb}$ downwind of Manaus. This is in good agreement with observed $\mathrm{O}_{3}$ mixing ratios of $\sim 50 \mathrm{ppb}$ at about $400 \mathrm{~m}$ altitude $10 \mathrm{~km}$ downwind of Manaus.

These results, based on the use of the São Paulo emission characteristics, apparently provide some reasonable firstorder estimate of the impact of the Manaus plume on the "green ocean" atmospheric chemistry conditions. However, Fig. 8 clearly indicates the role of some strong localized 
sources, in particular for $\mathrm{NO}_{\mathrm{x}}$. In order to study the impact of these enhanced emissions, a number of simulations were then conducted for which two grid points were added along the transect to resemble the location of the power plants (denoted by the points $1 \mathrm{PP}$ and $3 \mathrm{PP}$ in Fig. 1), being strong point sources for $\mathrm{NO}_{\mathrm{x}}$. The ratio of the source strength for the grid $1 \mathrm{PP}$ and $3 \mathrm{PP}$ was assumed to be 1:4, based on the indicated power supply of $\sim 125 \mathrm{MW}$ for the one power plant at location $1 \mathrm{PP}$ and $>560 \mathrm{MW}$ for the three power plants at location $3 \mathrm{PP}$, respectively. Applying an emission flux that added up to a total of $\sim 1.5 \mathrm{~kg} \mathrm{NO}_{\mathrm{x}} \mathrm{day}^{-1}$ for the four power plants, we then could simulate a $\mathrm{NO}_{\mathrm{x}}$ mixing ratio at $400 \mathrm{~m}$ altitude $10 \mathrm{~km}$ downwind of Manaus of $\sim 30 \mathrm{ppb}$ (Fig. 16), i.e., representative of the concentration range within the plume transects observed at this distance (see Fig. 8).

This source of about $1.5 \mathrm{~kg} \mathrm{NO}_{\mathrm{x}}$ day $^{-1}$ for four power plants producing in total about $700 \mathrm{MW}$ is comparable to the emission fluxes of $\mathrm{NO}_{\mathrm{x}}$ applied in a numerical modelling study by Dallarosa et al. (2007) on the impact of a Brazilian coal-fired power plant (with a capacity of $\sim 450 \mathrm{MW}$ ) on ozone production (note that the numbers provided by Dallarosa et al., Table 1 , should be in $\mathrm{g} \mathrm{day}^{-1}$ ). As a major precursor with respect to ozone production, these substantially larger $\mathrm{NO}_{\mathrm{x}}$ mixing ratios in the part of the Manaus plume affected by power plant emissions also have a pronounced impact on ozone mixing ratios as a function of the distance downwind. Figure 17 shows the simulated differences between the "power plant" and "urban area" plume ozone mixing ratios (power plant - urban plume) as a function of distance for the five CBL levels. In the near vicinity of Manaus, up to about $50 \mathrm{~km}$ downwind, the power plant emissions are simulated to result in a strong titration of ozone compared to the "urban area" plume, which is well reflecting the observations shown in Fig. 8. Further downwind the enhanced $\mathrm{NO}_{\mathrm{x}}$ mixing ratios give rise to an ozone enhancement with mixing ratios in the "power plant" plume being up to $20 \mathrm{ppb}$ larger compared to the "urban area" plume. The simulated absolute $\mathrm{O}_{3}$ mixing ratios at $400 \mathrm{~m}$ altitude $10 \mathrm{~km}$ downwind of Manaus in the urban plume and power plant plume of $\sim 50$ and $35 \mathrm{ppb}$, respectively, agree well with the observations shown in Fig. 8. The ozone production/destruction rates simulated by the SCM are well within the range reported in other studies of urban chemistry. The maximum ozone production rates reach up to about $35 \mathrm{ppb} \mathrm{h}^{-1}$ above Manaus in the "urban area" plume below $500 \mathrm{~m}$ altitude, whereas in the "power plant" plume there is initially a strong destruction of ozone, even at $400 \mathrm{~m}$ altitude as shown in Fig. 18. It also shows the contribution by other processes including turbulent and convective transport. These appear to play a minor role at this altitude in determining ozone mixing ratios up to $>100 \mathrm{~km}$ downwind of Manaus.

The high $\mathrm{NO}_{\mathrm{x}}$ mixing ratios in the power plant plume are modelled to also result in a strong relative decrease in simulated $\mathrm{OH}$ concentrations in the vicinity of Manaus $(\sim 50 \mathrm{~km})$ and an increase further downwind compared to the

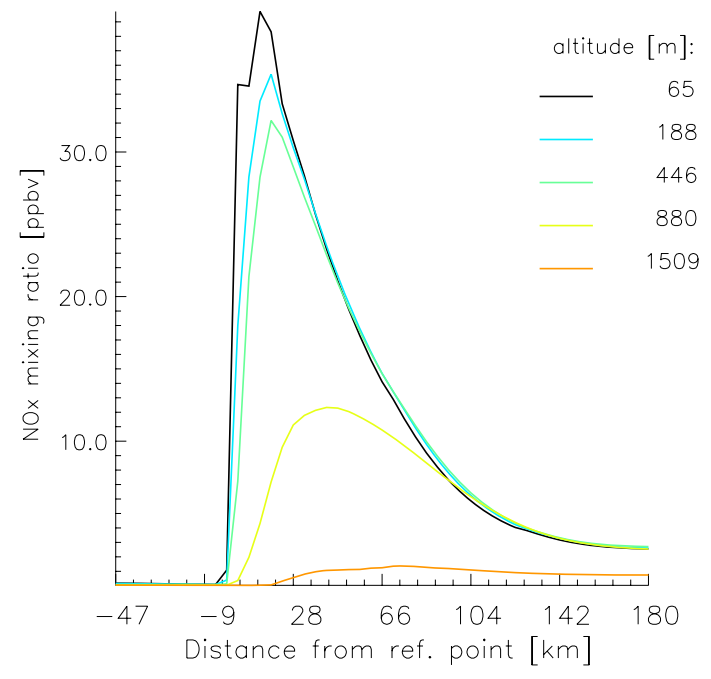

Fig. 16. Simulated $\mathrm{NO}_{\mathrm{x}}$ mixing ratio as in Fig. 14b, but for the simulations that consider the additional strong sources of $\mathrm{NO}_{\mathrm{x}}$ from the four power plants in Manaus.

urban plume simulations as shown in Fig. 19. The maximum absolute decrease near Manaus and the increase further downwind in the power plant plume of $\sim 20 \times 10^{6}$ molecules $\mathrm{OH} \mathrm{cm}{ }^{-3}$ compared to the urban plume $\mathrm{OH}$ concentrations resemble absolute concentrations in the urban plume of $\sim 25 \times 10^{6}$ molecules $\mathrm{OH} \mathrm{cm}^{-3}$. Nevertheless, an absolute decrease of $\mathrm{OH}$ with respect to background conditions, as inferred from the isoprene oxidation products MVK/MACR discussed above, was not predicted by the model. One possible explanation for this discrepancy might be the high loads of primary emission and secondary formation of aerosols, both inorganic and organic, which can modify the oxidation efficiency of the atmosphere by way of heterogeneous reactions that are not accounted adequately by the model.

In order to indicate the spatial extent of the potential impact of the Manaus plume on tropical forest downwind, total and dry deposition fluxes of gaseous nitrogen were also simulated, i.e., the summed deposition of all $\mathrm{NO}_{y}$ and $\mathrm{NH}_{\mathrm{x}}$ compounds of the chemistry scheme of the SCM (Ganzeveld et al., 2008). This showed the simulated N deposition downwind of the Manaus plume to decrease from a maximum of $\sim 70 \mathrm{~kg} \mathrm{Nha}^{-1} \mathrm{a}^{-1}$ close to Manaus to about $30 \mathrm{~kg} \mathrm{Nha}^{-1} \mathrm{a}^{-1}$ after three days of travel time, at a distance $>1500 \mathrm{~km}$ downwind of Manaus. To put these nitrogen estimates in perspective, we can compare our results with those of Trebs et al. (2006), who estimated the nitrogen deposition fluxes to a rural pasture site affected by land use practices and biomass burning emissions in the state of Rondonia, southwestern Brazil, to be around $11 \mathrm{~kg} \mathrm{Nha}^{-1} \mathrm{a}^{-1}$ (incl. $5.3 \mathrm{~kg} \mathrm{Nha}^{-1} \mathrm{a}^{-1}$ of wet deposition, and excluding the role of ammonia emissions, which are also not considered in this model analysis). Observations by Lara et al. (2001) of rainwater composition, thus excluding the 


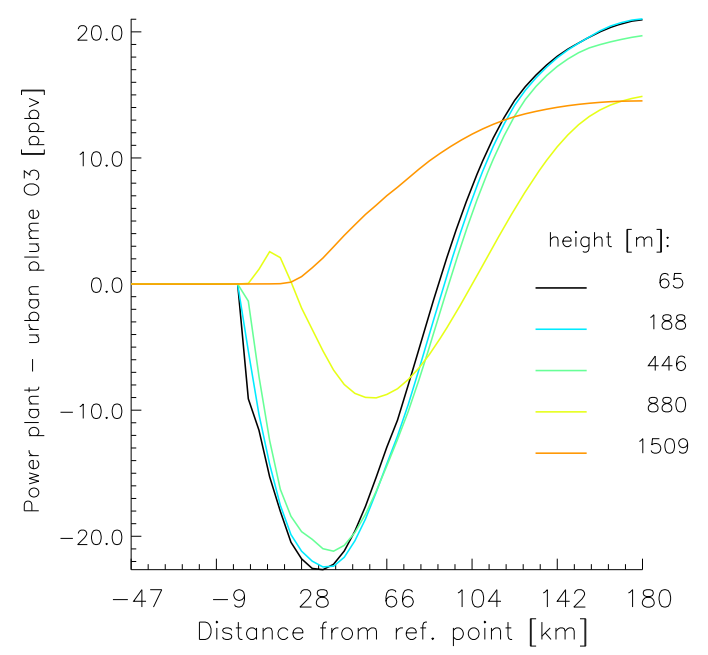

Fig. 17. Simulated absolute difference between the "power plant" and "urban area" plume ozone mixing ratio for the five CBL model levels as a function of the distance downwind of the eastern city limits of Manaus.

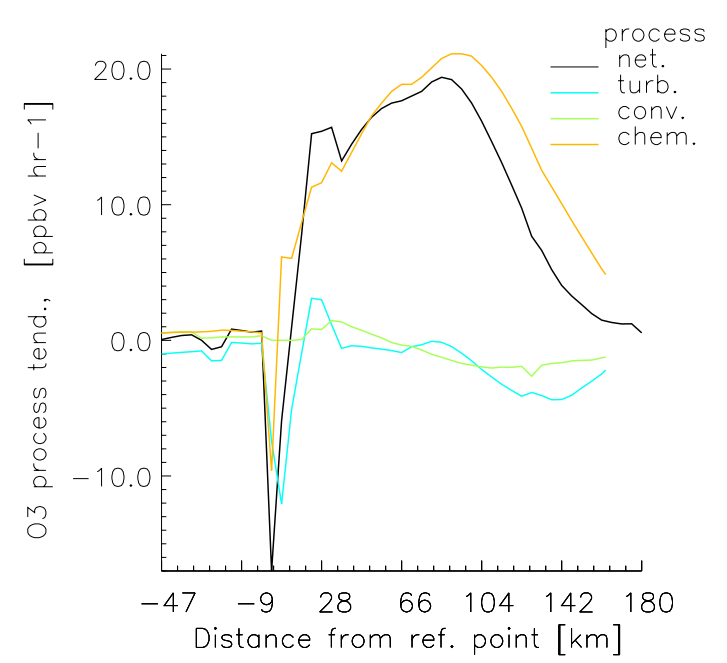

Fig. 18. Simulated ozone production/destruction rates in the "power plant" plume at $400 \mathrm{~m}$ altitude. The legends turb (cyan line), conv (green line), and chem (orange line) refer to the turbulent, convective and chemical tendencies, respectively, which together make up the total net tendency in $\mathrm{O}_{3}$ processes, referred to as net (black line).

contribution by dry deposition, indicated an annual $\mathrm{N}$ deposition of $54 \mathrm{~kg} \mathrm{~N} \mathrm{ha}^{-1} \mathrm{a}^{-1}$ in a river basin close to São Paulo. These findings may be discussed within the context of the impact of a potential excess of available $\mathrm{N}$ on carbon uptake by vegetation and acidification and eutrophication of the ecosystems and rivers associated with atmospheric $\mathrm{N}$ deposition. Despite the fact that our estimates are based only on a short integration time reflecting July conditions, they indicate that the Manaus City emissions could potentially have a profound impact on ecosystems far downwind through the input of nitrogen. Close to Manaus, the $\mathrm{N}$ deposition is deter-

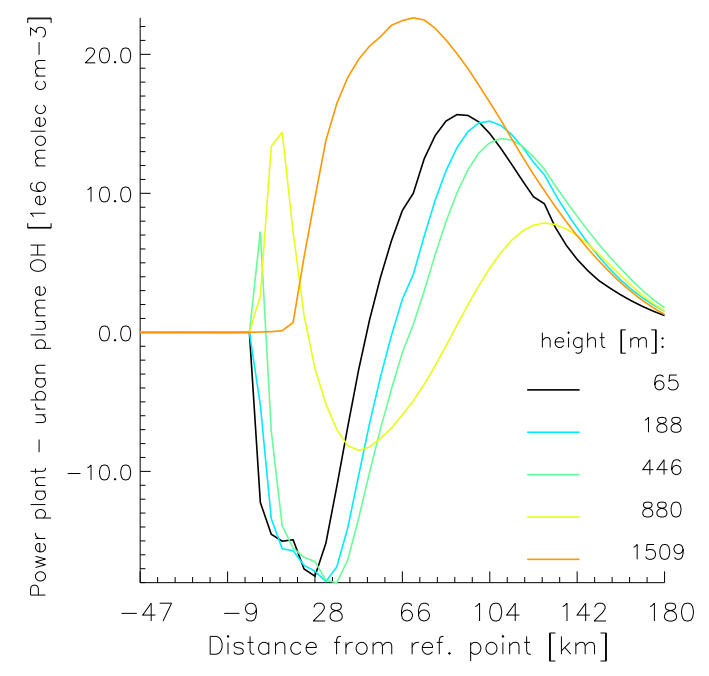

Fig. 19. Simulated absolute difference between the "power plant" and "urban area" plume $\mathrm{OH}$ concentrations for the five CBL model levels as a function of the distance downwind of the eastern city limits of Manaus.

mined mainly by $\mathrm{NO}_{2}$ dry deposition, but further downwind the fast conversion of $\mathrm{NO}_{2}$ into $\mathrm{NO}_{\mathrm{y}}$ species such as $\mathrm{HNO}_{3}$, which is efficiently removed by both dry and wet deposition, explains an increasingly important role of wet removal of nitrogen (Meixner, 1994; Fowler et al., 2009). The modelled $\mathrm{NO}_{\mathrm{x}}$ to $\mathrm{NO}_{\mathrm{y}}$ ratio only exceeds 0.8 directly in the plume over Manaus, but decreases rapidly to a value $<0.2$ further downwind, reflecting the efficient chemical conversion into $\mathrm{HNO}_{3}$ (maximum $\mathrm{HNO}_{3}$ production rate of $15 \mathrm{ppbh}^{-1}$ ) and PAN in the plume. It is unlikely that such high rates of $\mathrm{N}$ deposition would actually be benefiting the tropical forest vegetation. This is because, in accordance with general theory (Vitousek, 1994), there is now good evidence that the productivity of most Amazon forests is limited by $\mathrm{P}$, rather than by N availability (Quesada et al., 2009). Similarly, several lines of evidence also indicate that $\mathrm{N}$ is in excess for most tropical forest systems (Martinelli et al., 1999; Hedin et al., 2009; Quesada et al., 2010; Lloyd et al., 2010). On the other hand, the old and weathered ferralsol soils supporting much of the forest vegetation of this region (Quesada et al., 2010) may be particularly susceptible to acidification due to their low cation exchange capacity combined with a poor buffering capacity due to a low degree of base saturation (Kulyentiera et al., 2001). Both oxidized and reduced nitrogen species may result in acidification (Sanderson et al., 2006) and tropical soils might also be most sensitive to ecosystem acidification from anthropogenic sulphur deposition (Kulyentiera et al., 2001), not captured by the measurements during LBA-CLAIRE 2001. It furthermore has to be anticipated that enhanced ozone concentrations will impact the downwind ecosystems through foliar damage caused by ozone uptake. For all three days of the SCM, the maximum 
stomatal ozone uptake fluxes $\left(F_{\text {stomO3 }}\right)$ exceeded the critical threshold for broadleaf trees of $1.6 \mathrm{nmol} \mathrm{m}^{-2} \mathrm{~s}^{-1}$ as applied by Sitch et al. (2007) in a study of the role of ozone uptake on photosynthesis and radiative forcing. The simulated maximum $F_{\text {stomO3 }}$ of $4 \mathrm{nmol} \mathrm{m}^{-2} \mathrm{~s}^{-1}$ close to Manaus decreased to about $2 \mathrm{nmol} \mathrm{m}^{-2} \mathrm{~s}^{-1}$ only on the third day, at a travel distance $>1500 \mathrm{~km}$ downwind from Manaus.

\section{Conclusions}

In general, the high background mixing ratios of biogenic VOC within the tropical region favour fast $\mathrm{O}_{3}$ production and high yields immediately upon anthropogenic $\mathrm{NO}_{\mathrm{x}}$ emission in urban plumes. VOC compete with $\mathrm{NO}_{2}$ for the $\mathrm{OH}$ radicals, and the generated peroxy radicals convert $\mathrm{NO}$ into $\mathrm{NO}_{2}$, leading to $\mathrm{O}_{3}$ production. $\mathrm{NO}_{\mathrm{x}}$ emitted into isoprenerich "green ocean air" tends to produce more ozone per unit of $\mathrm{NO}_{\mathrm{x}}$ emitted, and to produce it more rapidly, than would be the case if those emissions had occurred in extra-tropical areas with a lower background of reactive VOCs, and less intense solar radiation. However, the strongly enhanced $\mathrm{NO}_{\mathrm{x}}$ emissions by the point sources of concentrated electric power plants such as found in Manaus, may lead to a relative reduction of ozone and $\mathrm{OH}$ formation in the vicinity of the source region. This was observed during relatively stagnant conditions of Flight \#11, which led to $\mathrm{VOC} / \mathrm{NO}_{\mathrm{x}}$ ratios sufficiently low that $\mathrm{O}_{3}$ formation was initially suppressed, probably in favour of efficient $\mathrm{HNO}_{3}$ production, thereby removing $\mathrm{NO}_{\mathrm{x}}$ from further participation in $\mathrm{O}_{3}$ formation cycles (see Neuman et al., 2002; Ryerson et al., 2001, 2003, Daum et al., 2000; Luria et al., 1999; Nunnermacker et al., 2000). However, further downwind of the source, enhanced $\mathrm{VOC} / \mathrm{NO}_{\mathrm{x}}$ ratios then resulted in a relatively stronger ozone enhancement. Hence a central issue that requires increased attention is the large-scale transport of regionally created air pollution. The SCM model results indicate that the relevant spatial scale for the ozone production in the Manaus plume extends far beyond the $100 \mathrm{~km}$ distance investigated during LBA-CLAIRE-2001. Photooxidant formation processes are non-linear with respect to the emission strength. This makes the development of abatement policies to meet air quality standards a challenging task. In addition, the importance of organic peroxide chemistry in SOA formation and the details of the underlying chemistry remain unclear. Further studies need to be based on numerical model simulations, ideally with validated three-dimensional (3-D) models, such as are currently under way.

Aerosol measurements in the Manaus plume showed that the city and the associated power plants were strong sources of aerosol particles. A large fraction of these added particles showed low light scattering and low $\mathrm{CCN}_{0.6} / \mathrm{CN}$ ratios. This suggests that the initial particles are very small $(<40 \mathrm{~nm}$ diameter), as has been observed in other urban areas. During the evolution of the plume over a few hours and some $100 \mathrm{~km}$ distance from the city, dilution-normalized $\mathrm{CN}$ numbers de- creased, while $\mathrm{CCN}_{0.6}$ and scattering efficiency increased, consistent with an expected increase in particles sizes associated with coagulation/condensation.

Data presented in this paper highlight only a few flights from one intensive study. Extrapolation of the analysis to the seasonal scales relevant for pollution reduction strategies was not in the scope of this LBA-CLAIRE activity. Nevertheless our results may help to elucidate the processes by which urban air pollutants are generated, dispersed, and transformed in the tropical atmosphere, and hence strengthen the scientific base for the evaluation of urbanisation policies in the Amazon Basin and other remote areas of the world. In the tropical background atmosphere, high loads of biogenic isoprene and its oxidation products result in an increase in peroxy radical concentrations and hence in ozone production, which are impossible to control; and ozone formation in this regime is strongly sensitive to nitrogen oxides emissions. The ozone production efficiency also varies depending on the strength of the $\mathrm{NO}_{\mathrm{x}}$ source. A large power plant generally has relatively lower ozone production efficiency than small sources (Ryerson et al., 1998; Nunnermacker et al., 2000; Frost et al., 2006). Due to the strong dependence of $\mathrm{O}_{3}$ production specifically in the low $\mathrm{NO}_{\mathrm{x}}$ concentration range, focusing urbanisation into a few zones of urbanisation (i.e., pooling of $\mathrm{NO}_{\mathrm{x}}$ sources) might be a favourable urbanisation policy in the Amazon Basin with regard to the ozone budget for the populated areas (near field), as compared to a ruralisation, i.e., a large-scale dispersion of small pollution sources. However, production and dispersion of PAN and other longlived reactive nitrogen compounds produced in the urban plume may result in a significant export of anthropogenic $\mathrm{NO}_{\mathrm{x}}$ to remote regions at greater distances, and hence may have a major effect on the oxidative capacity of the remote atmosphere through enhancement of the background $\mathrm{NO}_{\mathrm{x}}$ in otherwise unpolluted regions. The associated atmospheric $\mathrm{N}$ and ozone deposition also has to be considered in the context of its impact on ecosystem carbon balance, acidification and eutrophication.

As the formation of photooxidants and aerosols is tightly linked together through atmospheric chemical processes, respective emission reduction strategies must be evaluated together, as a strategy that is optimal for aerosols may interfere with an ozone reduction strategy, and vice versa (Meng et al., 1997; Neftel et al., 2002). Furthermore, combustion modification techniques and equipment is applied primarily for $\mathrm{NO}_{\mathrm{x}}$ control purposes, but can increase $\mathrm{CO}$ and VOC emissions if the modification techniques are improperly implemented or if the equipment is improperly designed (EPA AP42). The problems facing pollution abatement strategies are complex, from a scientific as well as a policy perspective, and challenge the international endeavours to improve air quality and reduce the radiative forcing of climate. More detailed studies are needed to advance the quantitative understanding of the oxidant cycle to improve the numerical models needed to develop decent mitigation strategies. Specifically the in- 
teractions and feedbacks between natural and anthropogenic sources of aerosol precursors are important for the aerosol loading and need to be investigated based on a detailed physical and chemical characterization and quantification in future experiments. Uncertainties in aerosol research include the characterization of the role of particulate matter (including ice-particles and droplets) in ozone/OH depletion and the chemical transformation of $\mathrm{NO}_{\mathrm{x}}$, and the interplay between secondary particulate matter and ozone/OH formation.

Acknowledgements. This study was carried out as part of the Large-Scale Atmosphere-Biosphere Experiment in Amazonia (LBA). It was supported by the German Max-Planck-Gesellschaft, the São Paulo State Fundação de Amparo à Pesquisa (FAPESP), and the Brazilian Conselho Nacional de Desenvolvimento Científico e Technológica ( $\mathrm{CNPq})$. We thank the pilots of the INPE Bandeirante aircraft for their enthusiastic and competent support throughout an intensive flying campaign. We also thank the National Counsel of Technological and Scientific Development, Brazil, for their support including provision of the aircraft; and the Instituto Nacional de Pesquisas da Amazonia (INPA) for logistic support. We credit the NOAA Air Resources Laboratory for making available the HYSPLIT model, and Google Earth ${ }^{\mathrm{TM}}$ mapping service for providing the land cover image.

The service charges for this open access publication have been covered by the Max Planck Society.

Edited by: J. Rinne

\section{References}

Andreae, M., Anderson, B., Blake, D., Bradshaw, J., Collins, J., Gregory, G., Sachse, G., and Shipham, M.: Influence of plumes from biomass burning on atmospheric chemistry over the equatorial and tropical South Atlantic during CITE 3, J. Geophys. Res., 99(D6), 12793-12808, 1994.

Andreae, M. O., Browell, E. V., Garstang, M., Gregory, G. L., Harriss, R. C., Hill, G. F., Jacob, D. J., Pereira, M. C., Sachse, G. W., Setzer, A. W., Dias, P. L. S., Talbot, R. W., Torres, A. L., and Wofsy, S. C.: Biomass-burning emissions and associated haze layers over Amazonia, J. Geophys. Res.-Atmos., 93(D2), 15091527, 1988.

Andreae, M. O.: The Biosphere: Pilot or Passenger on Spaceship Earth?, in: Contributions to global change research, edited by: Heinen, D., Hoch, S., Krafft, T., Moss, C., Scheidt, P., and Welschhoff A., German National Committee on Global Change Research, Bonn, 59-66, 2001.

Andreae, M. O. and Merlet, P.: Emission of trace gases and aerosols from biomass burning, Global Biogeochem. Cy., 15, 955-966, 2001.

Andreae, M. O., Artaxo, P., Brandao, C., Carswell, F. E., Ciccioli, P., da Costa, A. L., Culf, A. D., Esteves, J. L., Gash, J. H. C., Grace, J., Kabat, P., Lelieveld, J., Malhi, Y., Manzi, A. O., Meixner, F. X., Nobre, A. D., Nobre, C., Ruivo, M. D. L. P., Silva-Dias, M. A., Stefani, P., Valentini, R., von Jouanne, J., and Waterloo, M. J.: Biogeochemical cycling of carbon, water, energy, trace gases, and aerosols in Amazonia: The LBAEUSTACH experiments, J. Geophys. Res.-Atmos., 107(D20), 8066, doi:10.1029/2001JD000524, 2002.
Andreae, M. O. and Rosenfeld, D.: Aerosol-cloud-precipitation interactions. Part 1. The nature and sources of cloud-active aerosols, Earth-Sci. Rev., 89, 13-41, 2008.

Andreae, M. O.: Correlation between cloud condensation nuclei concentration and aerosol optical thickness in remote and polluted regions, Atmos. Chem. Phys., 9, 543-556, doi:10.5194/acp-9-543-2009, 2009.

Artaxo, P., Martins, J. V., Yamasoe, M. A., Procopio, A. S., Pauliquevis, T. M., Andreae, M. O., Guyon, P., Gatti, L. V., and Leal, A. M. C.: Physical and chemical properties of aerosols in the wet and dry seasons in Rondonia, Amazonia, J. Geophys. Res.-Atmos., 107(D20), 8081, doi:10.1029/2001JD000666, 2002.

Barket, D. J., Grossenbacher, J. W., Hurst, J. M., Shepson, P. B., Olszyna, K., Thornberry, T., Carroll, M. A., Roberts, J., Stroud, C., Bottenheim, J., and Biesenthal, T.: A study of the $\mathrm{NO}_{\mathrm{x}}$ dependence of isoprene oxidation, J. Geophys. Res.-Atmos., 109(D11), D11310, doi:10.1029/2003JD003965, 2004.

Betts, R. A., Malhi, Y., and Roberts, J. T.: The future of the Amazon: new perspectives from climate, ecosystem and social sciences, Philos. T. Roy. Soc. B-Biol. Sci., 363, 1729-1735, 2008.

Biesenthal, T. A., Wu, Q., Shepson, P. B., Wiebe, H. A., Anlauf, K. G., and Mackay, G. I.: A study of relationships between isoprene, its oxidation products, and ozone, in the Lower Fraser Valley, BC, Atmos. Environ., 31, 2049-2058, 1997.

Blake, N. J., Blake, D. R., Sive, B. C., Chen, T. Y., Rowland, F. S., Collins, J. E., Sachse, G. W., and Anderson, B. E.: Biomass burning emissions and vertical distribution of atmospheric methyl halides and other reduced carbon gases in the South Atlantic region, J. Geophys. Res.-Atmos., 101(D19), 24151-24164, 1996.

Bottenheim, J. W., Gallant, A. G., and Brice, K. A.: Measurements of $\mathrm{No}_{y}$ Species and $\mathrm{O}_{3}$ at 82-Degrees-N Latitude, Geophys. Res. Lett., 13, 113-116, 1986.

Brasseur, G. P., Prinn, R. G., and Pszenny A. A. P. (eds.): Atmospheric Chemistry in a Changing World, Springer Verlag, Heidelberg, Germany, 2003.

Bradshaw, J., Davis, D., Grodzinsky, G., Smyth, S., Newell, R., Sandholm, S., and Liu, S.: Observed distributions of nitrogen oxides in the remote free troposphere from the NASA global tropospheric experiment programs, Rev. Geophys., 38, 61-116, 2000.

Brock, C. A., Sullivan, A. P., Peltier, R. E., Weber, R. J., Wollny, A., Gouw, J. A., Middlebrook, A. M., Atlas, E. L., Stohl, A., Trainer, M. K., Cooper, O. R., Fehsenfeld, F. C., Frost, G. J., Holloway, J. S., Hubler, G., Neuman, J. A., Ryerson, T. B., Warneke, C., and Wilson, J. C.: Sources of particulate matter in the northeastern United States in summer: 2. Evolution of chemical and microphysical properties, J. Geophys. Res.-Atmos., 113(D8), D08302, doi:10.1029/2007JD009241, 2008.

Cantrell, C. A.: Technical Note: Review of methods for linear leastsquares fitting of data and application to atmospheric chemistry problems, Atmos. Chem. Phys., 8, 5477-5487, doi:10.5194/acp8-5477-2008, 2008.

Carter, W. P. L. and Atkinson, R.: Development and evaluation of a detailed mechanism for the atmospheric reactions of isoprene and $\mathrm{NO}_{\mathrm{x}}$, Int. J. Chem. Kinet., 28, 497-530, 1996.

Chameides, W. L., Lindsay, R. W., Richardson, J., and Kiang, C. S.: The role of biogenic hydrocarbons in urban photochemical smog - Atlanta as a case-study, Science, 241, 1473-1475, 1988.

Chameides, W. L., Fehsenfeld, F., Rodgers, M. O., Cardelino, C., 
Martinez, J., Parrish, D., Lonneman, W., Lawson, D. R., Rasmussen, R. A., Zimmerman, P., Greenberg, J., Middleton, P., and Wang, T.: Ozone precursor relationships in the ambient atmosphere, J. Geophys. Res.-Atmos., 97(D5), 6037-6055, 1992.

Chand, D., Schmid, O., Gwaze, P., Parmar, R. S., Helas, G., Zeromskiene, K., Wiedensohler, A., Massling, A., and Andreae, M. O.: Laboratory measurements of smoke optical properties from the burning of Indonesian peat and other types of biomass, Geophys. Res. Lett., 32(12), L12819, doi:10.1029/2005GL022678, 2005.

Chand, D., Guyon, P., Artaxo, P., Schmid, O., Frank, G. P., Rizzo, L. V., Mayol-Bracero, O. L., Gatti, L. V., and Andreae, M. O.: Optical and physical properties of aerosols in the boundary layer and free troposphere over the Amazon Basin during the biomass burning season, Atmos. Chem. Phys., 6, 2911-2925, doi:10.5194/acp-6-2911-2006, 2006.

Claeys, M., Graham, B., Vas, G., Wang, W., Vermeylen, R., Pashynska, V., Cafmeyer, J., Guyon, P., Andreae, M. O., Artaxo, P., and Maenhaut, W.: Formation of secondary organic aerosols through photooxidation of isoprene, Science, 303, 1173-1176, 2004.

Cordova, A. M., Longo, K., Freitas, S., Gatti, L. V., Artaxo, P., Procpio, A., Silva Dias, M. A. F., and Freitas, E. D.: Nitrogen oxides measurements in an Amazon site and enhancements associated with a cold front, Atmos. Chem. Phys. Discuss., 4, 2301-2331, doi:10.5194/acpd-4-2301-2004, 2004.

Crutzen, P. J., Delany, A. C., Greenberg, J., Haagenson, P., Heidt, L., Lueb, R., Pollock, W., Seiler, W., Wartburg, A., and Zimmerman, P.: Tropospheric chemical-composition measurements in Brazil during the dry season, J. Atmos. Chem., 2, 233-256, 1985.

Crutzen, P. J.: The role of the tropics in atmospheric chemistry, in: The Geophysiology of Amazonia, John Wiley, New York, 107130, 1987.

Dallarosa, J. B., Teixeira, E. C., and Alves, R. C. M.: Application of numerical models in the formation of ozone and its precursors in areas of influence of coal-fired power station - Brazil, Water Air Soil Poll., 178, 385-399, 2007.

Daum, P. H., Kleinman, L. I., Imre, D., Nunnermacker, L. J., Lee, Y. N., Springston, S. R., Newman, L., Weinstein-Lloyd, J., Valente, R. J., Imhoff, R. E., Tanner, R. L., and Meagher, J. F.: Analysis of $\mathrm{O}_{3}$ formation during a stagnation episode in central Tennessee in summer 1995, J. Geophys. Res.-Atmos., 105(D7), 9107-9119, 2000.

De Gouw, J. A., Brock, C. A., Atlas, E. L., Bates, T. S., Fehsenfeld, F. C., Goldan, P. D., Holloway, J. S., Kuster, W. C., Lerner, B. M., Matthew, B. M., Middlebrook, A. M., Onasch, T. B., Peltier, R. E., Quinn, P. K., Senff, C. J., Stohl, A., Sullivan, A. P., Trainer, M., Warneke, C., Weber, R. J., and Williams, E. J.: Sources of particulate matter in the northeastern United States in summer: 1. Direct emissions and secondary formation of organic matter in urban plumes, J. Geophys. Res.-Atmos., 113(D8), D08301, doi:10.1029/2007JD009243, 2008.

Dias, M. A. F. S., Rutledge, S., Kabat, P., Dias, P. L. S., Nobre, C., Fisch, G., Dolman, A. J., Zipser, E., Garstang, M., Manzi, A. O., Fuentes, J. D., Rocha, H. R., Marengo, J., Plana-Fattori, A., Sa, L. D. A., Alvala, R. C. S., Andreae, M. O., Artaxo, P., Gielow, R., and Gatti, L.: Cloud and rain processes in a biosphere-atmosphere interaction context in the Amazon Region, J. Geophys. Res.-Atmos., 107(D20), 8072, doi:10.1029/2001JD000335, 2002.
Dommen, J., Prevot, A. S. H., Neininger, B., and Baumle, M.: Characterization of the photooxidant formation in the metropolitan area of Milan from aircraft measurements, J. Geophys. Res.Atmos., 107(D22), 8197, doi:10.1029/2000JD000283, 2002.

Duncan, B. N., Stelson, A. W., and Kiang, C. S.: Estimated contribution of power-plants to ambient nitrogen-oxides measured in Atlanta, Georgia in August 1992, International Specialty Conference on Regional Photochemical Measurement and Modeling Studies, San Diego, Ca, 3043-3054, 1993.

Dunn, M. J., Jimenez, J. L., Baumgardner, D., Castro, T., McMurry, P. H., and Smith, J. N.: Measurements of Mexico City nanoparticle size distributions: Observations of new particle formation and growth, Geophys. Res. Lett., 31, L10102, doi:10.1029/2004GL019483, 2004.

Edney, E. O., Kleindienst, T. E., Jaoui, M., Lewandowski, M., Offenberg, J. H., Wang, W., and Claeys, M.: Formation of 2-methyl tetrols and 2-methylglyceric acid in secondary organic aerosol from laboratory irradiated isoprene/ $\mathrm{NO}_{X} / \mathrm{SO}_{2} /$ air mixtures and their detection in ambient PM2.5 samples collected in the eastern United States, Atmos. Environ., 39, 5281-5289, 2005.

Fisch, G., Tota, J., Machado, L. A. T., Dias, M., Lyra, R. F. D., Nobre, C. A., Dolman, A. J., and Gash, J. H. C.: The convective boundary layer over pasture and forest in Amazonia, Theor. Appl. Climatol., 78, 47-59, 2004.

Fowler D., Pilegaard, K., Sutton, M. A., et al.: Atmospheric composition change: Ecosystems-Atmosphere interactions, Atmos. Environ., 43, 5193-5267, 2009.

Freitas, S. R., Longo, K. M., Diasb, M., Diasb, P. L. S., Chatfield, R., Prins, E., Artaxo, P., Grell, G. A., and Recuero, F. S.: Monitoring the transport of biomass burning emissions in South America, Environ. Fluid. Mech., 5, 135-167, 2005.

Freud, E., Rosenfeld, D., Andreae, M. O., Costa, A. A., and Artaxo, P.: Robust relations between $\mathrm{CCN}$ and the vertical evolution of cloud drop size distribution in deep convective clouds, Atmos. Chem. Phys., 8, 1661-1675, doi:10.5194/acp-8-1661-2008, 2008.

Frost, G. J., McKeen, S. A., Trainer, M., Ryerson, T. B., Neuman, J. A., Roberts, J. M., Swanson, A., Holloway, J. S., Sueper, D. T., Fortin, T., Parrish, D. D., Fehsenfeld, F. C., Flocke, F., Peckham, S. E., Grell, G. A., Kowal, D., Cartwright, J., Auerbach, N., and Habermann, T.: Effects of changing power plant $\mathrm{NO}_{\mathrm{x}}$ emissions on ozone in the eastern United States: Proof of concept, J. Geophys. Res.-Atmos., 111(D12), D12306, doi:10.1029/2005JD006354, 2006.

Fuzzi, S., Decesari, S., Facchini, M. C., Cavalli, F., Emblico, L., Mircea, M., Andreae, M. O., Trebs, I., Hoffer, A., Guyon, P., Artaxo, P., Rizzo, L. V., Lara, L. L., Pauliquevis, T., Maenhaut, W., Raes, N., Chi, X. G., Mayol-Bracero, O. L., SotoGarcia, L. L., Claeys, M., Kourtchev, I., Rissler, J., Swietlicki, E., Tagliavini, E., Schkolnik, G., Falkovich, A. H., Rudich, Y., Fisch, G., and Gatti, L. V.: Overview of the inorganic and organic composition of size-segregated aerosol in Rondonia, Brazil, from the biomass-burning period to the onset of the wet season, J. Geophys. Res.-Atmos., 112(D1), D01201, doi:10.1029/2005JD006741, 2007.

Ganzeveld, L. and Lelieveld, J.: Impact of Amazonian deforestation on atmospheric chemistry, Geophys. Res. Lett., 31, L06105, doi:10.1029/2003GL019205, 2004.

Ganzeveld, L., Eerdekens, G., Feig, G., Fischer, H., Harder, H., 
Königstedt, R., Kubistin, D., Martinez, M., Meixner, F. X., Scheeren, H. A., Sinha, V., Taraborrelli, D., Williams, J., VilàGuerau de Arellano, J., and Lelieveld, J.: Surface and boundary layer exchanges of volatile organic compounds, nitrogen oxides and ozone during the GABRIEL campaign, Atmos. Chem. Phys., 8, 6223-6243, doi:10.5194/acp-8-6223-2008, 2008.

Ganzeveld, L. N., Lelieveld, J., Dentener, F. J., Krol, M. C., and Roelofs, G. J.: Atmosphere-biosphere trace gas exchanges simulated with a single-column model, J. Geophys. Res.-Atmos., 107, 4297, doi:10.1029/2001JD000684, 2002.

Garstang, M., Scala, J., Greco, S., Harriss, R., Beck, S., Browell, E., Sachse, G., Gregory, G., Hill, G., Simpson, J., Tao, W. K., and Torres, A.: Trace gas exchanges and convective transports over the Amazonian rainforest, J. Geophys. Res.-Atmos., 93(D2), 1528-1550, 1988.

Goldstein, A. H., Koven, C. D., Heald, C. L., and Fung, I. Y.: Biogenic carbon and anthropogenic pollutants combine to form a cooling haze over the southeastern United States, P. Natl. Acad. Sci. USA, 106, 8835-8840, 2009.

Graf, H. F. and Timmreck, C.: A general climate model simulation of the aerosol radiative effects of the Laacher See eruption (10900 BC), J. Geophys. Res.-Atmos., 106, 14747-14756, 2001.

Guenther, A., Hewitt, C. N., Erickson, D., Fall, R., Geron, C., Graedel, T., Harley, P., Klinger, L., Lerdau, M., McKay, W. A., Pierce, T., Scholes, B., Steinbrecher, R., Tallamraju, R., Taylor, J., and Zimmerman, P.: A global-model of natural volatile organic-compound emissions, J. Geophys. Res.-Atmos., 100(D5), 8873-8892, 1995.

Gunthe, S. S., King, S. M., Rose, D., Chen, Q., Roldin, P., Farmer, D. K., Jimenez, J. L., Artaxo, P., Andreae, M. O., Martin, S. T., and Pöschl, U.: Cloud condensation nuclei in pristine tropical rainforest air of Amazonia: size-resolved measurements and modeling of atmospheric aerosol composition and CCN activity, Atmos. Chem. Phys., 9, 7551-7575, doi:10.5194/acp-9-75512009, 2009.

Gut, A., van Dijk, S. M., Scheibe, M., Rummel, U., Welling, M., Ammann, C., Meixner, F. X., Kirkman, G. A., Andreae, M. O., and Lehmann, B. E.: NO emission from an Amazonian rain forest soil: Continuous measurements of NO flux and soil concentration, J. Geophys. Res.-Atmos., 107(D20), 8057, doi:10.1029/2001JD000521, 2002.

Guyon, P., Graham, B., Roberts, G. C., Mayol-Bracero, O. L., Maenhaut, W., Artaxo, P., and Andreae, M. O.: In-canopy gradients, composition, sources, and optical properties of aerosol over the Amazon forest, J. Geophys. Res.-Atmos., 108(D18), 4591, doi:10.1029/2003JD003465, 2003.

Guyon, P., Frank, G. P., Welling, M., Chand, D., Artaxo, P., Rizzo, L., Nishioka, G., Kolle, O., Fritsch, H., Silva Dias, M. A. F, Gatti, L. V., Cordova, A. M., and Andreae, M. O.: Airborne measurements of trace gas and aerosol particle emissions from biomass burning in Amazonia, Atmos. Chem. Phys., 5, 29893002, doi:10.5194/acp-5-2989-2005, 2005.

Harriss, R. C., Sachse, G. W., Hill, G. F., Wade, L. O., and Gregory, G. L.: Carbon-Monoxide over the Amazon Basin During the Wet Season, J. Geophys. Res.-Atmos., 95, 16927-16932, 1990.

Hedin, L. O., Brookshire, E. N. J., Menge, D. N. L., and Barron, A. R.: The Nitrogen Paradox in Tropical Forest Ecosystems, Annual Review of Ecology, Evolution, and Systematics, 40, 613-635, 2009.
Huntrieser, H., Schlager, H., Roiger, A., Lichtenstern, M., Schumann, U., Kurz, C., Brunner, D., Schwierz, C., Richter, A., and Stohl, A.: Lightning-produced $\mathrm{NO}_{\mathrm{x}}$ over Brazil during TROCCINOX: airborne measurements in tropical and subtropical thunderstorms and the importance of mesoscale convective systems, Atmos. Chem. Phys., 7, 2987-3013, doi:10.5194/acp-7-29872007, 2007.

Jacob, D. J. and Wofsy, S. C.: Photochemistry of biogenic emissions over the Amazon forest, J. Geophys. Res.-Atmos., 93(D2), 1477-1486, 1988.

Jacobson, M. Z. and Seinfeld, J. H.: Evolution of nanoparticle size and mixing state near the point of emission, Atmos. Environ., 38, 1839-1850, 2004.

Jiang, M., Marr, L. C., Dunlea, E. J., Herndon, S. C., Jayne, J. T., Kolb, C. E., Knighton, W. B., Rogers, T. M., Zavala, M., Molina, L. T., and Molina, M. J.: Vehicle fleet emissions of black carbon, polycyclic aromatic hydrocarbons, and other pollutants measured by a mobile laboratory in Mexico City, Atmos. Chem. Phys., 5, 3377-3387, doi:10.5194/acp-5-3377-2005, 2005.

Joos, E., Millancourt, B., Vanduuren, H., and Romer, F. G.: Physicochemical study by 2 aircraft of a plume from a coal-fired powerplant, Part a-General Topics, Atmos. Environ., 24(3), 703-710, 1990.

Jost, C., Trentmann, J., Sprung, D., Andreae, M. O., McQuaid, J. B., and Barjat, H.: Trace gas chemistry in a young biomass burning plume over Namibia: Observations and model simulations, J. Geophys. Res.-Atmos., 108(D13), 8482, doi:10.1029/2002JD002431, 2003.

Kanakidou, M., Tsigaridis, K., Dentener, F. J., and Crutzen, P. J.: Human-activity-enhanced formation of organic aerosols by biogenic hydrocarbon oxidation, J. Geophys. Res.-Atmos., 105(D7), 9243-9254, 2000.

Kaplan, W. A., Wofsy, S. C., Keller, M., and Dacosta, J. M.: Emission of $\mathrm{NO}$ and deposition of $\mathrm{O}_{3}$ in a tropical forest system, J. Geophys. Res.-Atmos., 93(D2), 1389-1395, 1988.

Karl, M., Dorn, H. P., Holland, F., Koppmann, R., Poppe, D., Rupp, L., Schaub, A., and Wahner, A.: Product study of the reaction of $\mathrm{OH}$ radicals with isoprene in the atmosphere simulation chamber SAPHIR, J. Atmos. Chem., 55, 167-187, 2006.

Karl, T., Guenther, A., Yokelson, R. J., Greenberg, J., Potosnak, M., Blake, D. R., and Artaxo, P.: The tropical forest and fire emissions experiment: Emission, chemistry, and transport of biogenic volatile organic compounds in the lower atmosphere over Amazonia, J. Geophys. Res.-Atmos., 112(D18), D18302, doi:10.1029/2007JD008539, 2007.

Kaufman, Y. J., Setzer, A., Ward, D., Tanre, D., Holben, B. N., Menzel, P., Pereira, M. C., and Rasmussen, R.: Biomass burning airborne and spaceborne experiment in the Amazonas (Base-a), J. Geophys. Res.-Atmos., 97(D13), 14581-14599, 1992.

Kavouras, I. G., Mihalopoulos, N., and Stephanou, E. G.: Formation and gas/particle partitioning of monoterpenes photooxidation products over forests, Geophys. Res. Lett., 26, 55-58, 1999.

Kesselmeier, J., Kuhn, U., Rottenberger, S., Biesenthal, T., Wolf, A., Schebeske, G., Andreae, M. O., Ciccioli, P., Brancaleoni, E., Frattoni, M., Oliva, S. T., Botelho, M. L., Silva, C. M. A., and Tavares, T. M.: Concentrations and species composition of atmospheric volatile organic compounds (VOCs) as observed during the wet and dry season in Ron- 
donia (Amazonia), J. Geophys. Res.-Atmos., 107(D20), 8053, doi:10.1029/2000JD000267, 2002.

Kleinman, L. I., Daum, P. H., Imre, D. G., Lee, J. H., Lee, Y. N., Nunnermacker, L. J., Springston, S. R., Weinstein-Lloyd, J., and Newman, L.: Ozone production in the New York City urban plume, J. Geophys. Res.-Atmos., 105(D11), 14495-14511, 2000.

Kleinman, L. I., Daum, P. H., Imre, D., Lee, Y. N., Nunnermacker, L. J., Springston, S. R., Weinstein-Lloyd, J., and Rudolph, J.: Ozone production rate and hydrocarbon reactivity in 5 urban areas: A cause of high ozone concentration in Houston, Geophys. Res. Lett., 29, 1467, doi:10.1029/2001GL014569, 2002.

Kleinman, L. I., Daum, P. H., Imre, D., Lee, Y. N., Nunnermacker, L. J., Springston, S. R., Weinstein-Lloyd, J., and Rudolph, J.: Ozone production rate and hydrocarbon reactivity in 5 urban areas: A cause of high ozone concentration in Houston (vol 30, pg 1639, 2003), Geophys. Res. Lett., 30, 1639, doi:10.1029/2003GL017485, 2003.

Kleinman, L. I., Daum, P. H., Lee, Y. N., Nunnermacker, L. J., Springston, S. R., Weinstein-Lloyd, J., and Rudolph, J.: A comparative study of ozone production in five U.S. metropolitan areas, J. Geophys. Res.-Atmos., 110(D2), D02301, doi:10.1029/2004JD005096, 2005.

Kleinman, L. I., Springston, S. R., Wang, J., Daum, P. H., Lee, Y.-N., Nunnermacker, L. J., Senum, G. I., Weinstein-Lloyd, J., Alexander, M. L., Hubbe, J., Ortega, J., Zaveri, R. A., Canagaratna, M. R., and Jayne, J.: The time evolution of aerosol size distribution over the Mexico City plateau, Atmos. Chem. Phys., 9, 4261-4278, doi:10.5194/acp-9-4261-2009, 2009.

Kroll, J. H., Ng, N. L., Murphy, S. M., Flagan, R. C., and Seinfeld, J. H.: Secondary organic aerosol formation from isoprene photooxidation under high- $\mathrm{NO}_{\mathrm{x}}$ conditions, Geophys. Res. Lett., 32(4), L18808, doi:10.1029/2005GL023637, 2005.

Kroll, J. H., Ng, N. L., Murphy, S. M., Flagan, R. C., and Seinfeld, J. H.: Secondary organic aerosol formation from isoprene photooxidation, Environ. Sci. Technol., 40, 1869-1877, 2006.

Kuhn, U., Rottenberger, S., Biesenthal, T., Wolf, A., Schebeske, G., Ciccioli, P., Brancaleoni, E., Frattoni, M., Tavares, T. M., and Kesselmeier, J.: Isoprene and monoterpene emissions of Amazonian tree species during the wet season: Direct and indirect investigations on controlling environmental functions, J. Geophys. Res.-Atmos., 107(D20), 8071, doi:10.1029/2001JD000978, 2002.

Kuhn, U., Rottenberger, S., Biesenthal, T., Wolf, A., Schebeske, G., Ciccioli, P., Brancaleoni, E., Frattoni, M., Tavares, T. M., and Kesselmeier, J.: Seasonal differences in isoprene and lightdependent monoterpene emission by Amazonian tree species, Glob. Change Biol., 10, 663-682, 2004a.

Kuhn, U., Rottenberger, S., Biesenthal, T., Wolf, A., Schebeske, G., Ciccioli, P., and Kesselmeier, J.: Strong correlation between isoprene emission and gross photosynthetic capacity during leaf phenology of the tropical tree species Hymenaea courbaril with fundamental changes in volatile organic compounds emission composition during early leaf development, Plant Cell Environ., 27, 1469-1485, 2004b.

Kuhn, U., Dindorf, T., Ammann, C., Rottenberger, S., Guyon, P., Holzinger, R., Ausma, S., Kenntner, T., Helleis, F., and Kesselmeier, J.: Design and field application of an automated cartridge sampler for VOC concentration and flux measurements,
J. Environ. Monit., 7, 568-576, 2005.

Kuhn, U., Andreae, M. O., Ammann, C., Araújo, A. C., Brancaleoni, E., Ciccioli, P., Dindorf, T., Frattoni, M., Gatti, L. V., Ganzeveld, L., Kruijt, B., Lelieveld, J., Lloyd, J., Meixner, F X., Nobre, A. D., Pöschl, U., Spirig, C., Stefani, P., Thielmann, A., Valentini, R., and Kesselmeier, J.: Isoprene and monoterpene fluxes from Central Amazonian rainforest inferred from towerbased and airborne measurements, and implications on the atmospheric chemistry and the local carbon budget, Atmos. Chem. Phys., 7, 2855-2879, doi:10.5194/acp-7-2855-2007, 2007.

Moura, M. A. L., Meixner, F. X., Trebs, I., Molion, L. C. B., and do Nascimento Filho, M. F.: Medições de NO-NO $2-\mathrm{O}_{3}$ na Amazônia central durante o experimento LBA/CLAIRE-2001, Revista Brasileira de Meteorologia, 19(1), 49-58, 2004.

Lara, L., Artaxo, P., Martinelli, L. A., Victoria, R. L., Camargo, P. B., Krusche, A., Ayers, G. P., Ferraz, E. S. B., and Ballester, M. V.: Chemical composition of rainwater and anthropogenic influences in the Piracicaba River Basin, Southeast Brazil, Atmos. Environ., 35, 4937-4945, 2001.

Lathière, J., Hauglustaine, D. A., Friend, A. D., De NobletDucoudré, N., Viovy, N., and Folberth, G. A.: Impact of climate variability and land use changes on global biogenic volatile organic compound emissions, Atmos. Chem. Phys., 6, 2129-2146, doi:10.5194/acp-6-2129-2006, 2006.

Lelieveld, J. and Crutzen, P. J.: Role of Deep Cloud Convection in the Ozone Budget of the Troposphere, Science, 264, 1759-1761, 1994.

Lelieveld, J., Dentener, F. J., Peters, W., and Krol, M. C.: On the role of hydroxyl radicals in the self-cleansing capacity of the troposphere, Atmos. Chem. Phys., 4, 2337-2344, doi:10.5194/acp4-2337-2004, 2004.

Lelieveld, J., Butler, T. M., Crowley, J. N., Dillon, T. J., Fischer, H., Ganzeveld, L., Harder, H., Lawrence, M. G., Martinez, M., Taraborrelli, D., and Williams, J.: Atmospheric oxidation capacity sustained by a tropical forest, Nature, 452, 737-740, 2008.

Lin, X., Trainer, M., and Liu, S. C.: On the nonlinearity of the tropospheric ozone production, J. Geophys. Res.-Atmos., 93, 15879_ $15888,1988$.

Liu, S. C., Trainer, M., Fehsenfeld, F. C., Parrish, D. D., Williams, E. J., Fahey, D. W., Hubler, G., and Murphy, P. C.: Ozone production in the rural troposphere and the implications for regional and global ozone distributions, J. Geophys. Res.-Atmos., 92, 4191-4207, 1987.

Lloyd, J., Francey, R. J., Mollicone, D., Raupach, M. R., Sogachev, A., Arneth, A., Byers, J. N., Kelliher, F. M., Rebmann, C., Valentini, R., Wong, S. C., Bauer, G., and Schulze, E. D.: Vertical profiles, boundary layer budgets, and regional flux estimates for $\mathrm{CO}_{2}$ and its $\mathrm{C}^{13} / \mathrm{C}^{12}$ ratio and for water vapor above a forest/bog mosaic in central Siberia, Global Biogeochem. Cy., 15, 267-284, 2001.

Lloyd, J., Goulden, M., Ometto, J. P., Fyllas, N. M., Quesada, C. A., and Patiño, S.: Ecophysiology of forest and savanna vegetation, in: Amazonia and Climate Change, edited by: Keller, M., Gash, J., and Silva Dias, P., in press, 2010.

Lloyd, J., Kolle, O., Fritsch, H., de Freitas, S. R., Silva Dias, M. A. F., Artaxo, P., Nobre, A. D., de Araújo, A. C., Kruijt, B., Sogacheva, L., Fisch, G., Thielmann, A., Kuhn, U., and Andreae, M. O.: An airborne regional carbon balance for Central Amazonia, Biogeosciences, 4, 759-768, doi:10.5194/bg-4-759-2007, 
2007.

Logan, J. A.: Tropospheric ozone - seasonal behavior, trends, and anthropogenic influence, J. Geophys. Res.-Atmos., 90(D6), 10463-10482, 1985.

Logan, J. A., Prather, M. J., Wofsy, S. C., and McElroy, M. B.: Tropospheric chemistry: a global perspective, J. Geophys. Res., 86, 7210-7254, 1981.

Luria, M., Valente, R. J., Tanner, R. L., Gillani, N. V., Imhoff, R. E., Mueller, S. F., Olszyna, K. J., and Meagher, J. F.: The evolution of photochemical smog in a power plant plume, Atmos. Environ., 33, 3023-3036, 1999.

Luria, M., Tanner, R. L., Imhoff, R. E., Valente, R. J., Bailey, E. M., and Mueller, S. F.: Influence of natural hydrocarbons on ozone formation in an isolated power plant plume, J. Geophys. Res.Atmos., 105(D7), 9177-9188, 2000.

Martin, S. T., Andreae, M. O., Artaxo, P., Baumgardner, D., Chen, Q., Goldstein, A. H., Guenther, A., Heald, C. L., Mayol-Bracero, O. L., McMurry, P. H., Pauliquevis, T. P. U., Prather, K. A., Roberts, G. C., Saleska, S. R., Dias, M. A. S., Spracklen, D., Swietlicki, E., and Trebs, I.: Sources and properties of Amazonian aerosol particles, Rev. Geophys., 48, RG2002, doi:10.1029/2008RG000280, 2010a

Martin, S. T., Andreae, M. O., Althausen, D., Artaxo, P., Baars, H., Borrmann, S., Chen, Q., Farmer, D. K., Guenther, A., Gunthe, S. S., Jimenez, J. L., Karl, T., Longo, K., Manzi, A., Pauliquevis, T., Petters, M. D., Prenni, A. J., Pöschl, U., Rizzo, L. V., Schneider, J., Smith, J. N., Swietlicki, E., Tota, J., Wang, J., Wiedensohler, A., and Zorn, S. R.: An overview of the Amazonian Aerosol Characterization Experiment 2008 (AMAZE-08), Atmos. Chem. Phys. Discuss., 10, 18139-18195, doi:10.5194/acpd-10-181392010, 2010b.

Martinelli, L. A., Piccolo, M. C., Townsend, A. R., Vitousek, P. M., Cuevas, E., McDowell, W., Robertson, G. P., Santos, O. C., and Treseder, K.: Nitrogen stable isotopic composition of leaves and soil: Tropical versus temperate forests, Biogeochemistry, 46, 45-65, 1999.

Martins, L. D., Andrade, M. F., D Freitas, E., Pretto, A., Gatti, L. V., Albuquerque, E. L., Tomaz, E., Guardani, M. L., Martins, M., and Junior, O. M. A.: Emission factors for gas-powered vehicles travelling through road tunnels in Sao Paulo, Brazil, Environ. Sci. Technol., 40, 6722-6729, 2006.

Matsunaga, S., Mochida, M., and Kawamura, K.: Growth of organic aerosols by biogenic semi-volatile carbonyls in the forestal atmosphere, Atmos. Environ., 37, 2045-2050, 2003.

Matsunaga, S., Mochida, M., and Kawamura, K.: Variation on the atmospheric concentrations of biogenic carbonyl compounds and their removal processes in the northern forest at Moshiri, Hokkaido Island in Japan, J. Geophys. Res.-Atmos., 109(9), D04302, doi:10.1029/2003JD004100, 2004.

Mauzerall, D. L., Logan, J. A., Jacob, D. J., Anderson, B. E., Blake, D. R., Bradshaw, J. D., Heikes, B., Sachse, G. W., Singh, H., and Talbot, B.: Photochemistry in biomass burning plumes and implications for tropospheric ozone over the tropical South Atlantic, J. Geophys. Res.-Atmos., 103(D7), 8401-8423, 1998.

McClenny, W. A., Williams, E. J., Cohen, R. C., and Stutz, J.: Preparing to measure the effects of the NOxSIP call-methods for ambient air monitoring of $\mathrm{NO}, \mathrm{NO}_{2}, \mathrm{NO}$ gamma, and individual $\mathrm{NO}_{Z}$ species, J Air Waste Manage., 52, 542-562, 2002.

McMurry, P. H., Fink, M., Sakurai, H., Stolzenburg, M. R.,
Mauldin, R. L., Smith, J., Eisele, F., Moore, K., Sjostedt, S., Tanner, D., Huey, L. G., Nowak, J. B., Edgerton, E., and Voisin, D.: A criterion for new particle formation in the sulfur-rich Atlanta atmosphere, J. Geophys. Res.-Atmos., 110(10), D22S02, doi:10.1029/2005JD005901, 2005.

Meixner, F. X.: Surface exchange of odd nitrogen oxides, Nova Acta Leopoldina NF 70, Nr. 288, 299-348, 1994.

Meng, Z., Dabdub, D., and Seinfeld, J. H.: Chemical coupling between atmospheric ozone and particulate matter, Science, 277 , 116-119, 1997.

Molina, M. J., Ivanov, A. V., Trakhtenberg, S., and Molina, L. T.: Atmospheric evolution of organic aerosol, Geophys. Res. Lett., 31, L22104, doi:10.1029/2004GL020910, 2004.

Molina, M. J. and Molina, L. T.: Megacities and atmospheric pollution, J. Air Waste Manage., 54, 644-680, 2004.

Neftel, A., Spirig, C., Prevot, A. S. H., Furger, M., Stutz, J., Vogel, B., and Hjorth, J.: Sensitivity of photooxidant production in the Milan Basin: An overview of results from a EUROTRAC-2 Limitation of Oxidant Production field experiment, J. Geophys. Res.Atmos., 107(D22), 8188, doi:10.1029/2001JD001263, 2002.

Neuman, J. A., Huey, L. G., Dissly, R. W., Fehsenfeld, F. C., Flocke, F., Holecek, J. C., Holloway, J. S., Hubler, G., Jakoubek, R., Nicks, D. K., Parrish, D. D., Ryerson, T. B., Sueper, D. T., and Weinheimer, A. J.: Fast-response airborne in situ measurements of $\mathrm{HNO}_{3}$ during the Texas 2000 Air Quality Study, J. Geophys. Res.-Atmos., 107(D20), 4436, doi:10.1029/2001JD001437, 2002.

Ng, N. L., Chhabra, P. S., Chan, A. W. H., Surratt, J. D., Kroll, J. H., Kwan, A. J., McCabe, D. C., Wennberg, P. O., Sorooshian, A., Murphy, S. M., Dalleska, N. F., Flagan, R. C., and Seinfeld, J. H.: Effect of $\mathrm{NO}_{\mathrm{x}}$ level on secondary organic aerosol (SOA) formation from the photooxidation of terpenes, Atmos. Chem. Phys., 7, 5159-5174, doi:10.5194/acp-7-5159-2007, 2007.

Nicks, D. K., Holloway, J. S., Ryerson, T. B., Dissly, R. W., Parrish, D. D., Frost, G. J., Trainer, M., Donnelly, S. G., Schauffler, S., Atlas, E. L., Hubler, G., Sueper, D. T., and Fehsenfeld, F. C.: Fossil-fuelled power plants as a source of atmospheric carbon monoxide, J. Environ. Monit., 5, 35-39, 2003.

Nober, F. J., Graf, H. F., and Rosenfeld, D.: Sensitivity of the global circulation to the suppression of precipitation by anthropogenic aerosols, Global Planet. Change, 37, 57-80, 2003.

Nunnermacker, L. J., Kleinman, L. I., Imre, D., Daum, P. H., Lee, Y. N., Lee, J. H., Springston, S. R., Newman, L., and Gillani, N.: $\mathrm{NO}_{y}$ lifetimes and $\mathrm{O}_{3}$ production efficiencies in urban and power plant plumes: Analysis of field data, J. Geophys. Res.-Atmos., 105(D7), 9165-9176, 2000.

Oke, T. R.: Urban climatology and the tropical city, in: Proceedings of the technical conference on urban climatology and its applications with special regard to tropical areas, edited by: Oke, T. R., Secretariat of the World Meteorological Organization (WMO Report 652), Geneva, Switzerland, 1986.

Pandis, S. N., Wexler, A. S., and Seinfeld, J. H.: Dynamics of the tropospheric aerosol, J. Phys. Chem., 99(24), 9646-9659, 1995.

Petters, M. D. and Kreidenweis, S. M.: A single parameter representation of hygroscopic growth and cloud condensation nucleus activity, Atmos. Chem. Phys., 7, 1961-1971, doi:10.5194/acp-71961-2007, 2007.

Pickering, K. E., Thompson, A. M., Dickerson, R. R., Luke, W. T., McNamara, D. P., Greenberg, J. P., and Zimmerman, P. R.: 
Model-calculations of tropospheric ozone production potential following observed convective events, J. Geophys. Res.-Atmos., 95(D9), 14049-14062, 1990.

Pickering, K. E., Thompson, A. M., Scala, J. R., Tao, W. K., Dickerson, R. R., and Simpson, J.: Free tropospheric ozone production following entrainment of urban plumes into deep convection, $\mathrm{J}$. Geophys. Res.-Atmos., 97(D16), 17985-18000, 1992.

Pope, C. A. and Dockery, D. W.: Health effects of fine particulate air pollution: Lines that connect, Conference proceedings of the 99th Annual Meeting of the Air-and-Waste-ManagementAssociation, New Orleans, LA, 709-742, 2006.

Pöschl, U., Martin, S. T., Sinha, B., et al., Rainforest aerosols as biogenic nuclei of clouds and precipitation in the Amazon, Science, 329, 1513-1516, 2010.

Potosnak, M. J., Wofsy, S. C., Denning, A. S., Conway, T. J., Munger, J. W., and Barnes, D. H.: Influence of biotic exchange and combustion sources on atmospheric $\mathrm{CO}_{2}$ concentrations in New England from observations at a forest flux tower, J. Geophys. Res.-Atmos., 104, 9561-9569, 1999.

Presto, A. A., Hartz, K. E. H., and Donahue, N. M.: Secondary organic aerosol production from terpene ozonolysis. 2. Effect of $\mathrm{NO}_{\mathrm{x}}$ concentration, Environ. Sci. Technol., 39, 7046-7054, 2005.

Quesada, C. A., Lloyd, J., Schwarz, M., Baker, T. R., Phillips, O. L., Patiño, S., Czimczik, C., Hodnett, M. G., Herrera, R., Arneth, A., Lloyd, G., Malhi, Y., Dezzeo, N., Luizão, F. J., Santos, A. J. B., Schmerler, J., Arroyo, L., Silveira, M., Priante Filho, N., Jimenez, E. M., Paiva, R., Vieira, I., Neill, D. A., Silva, N., Peñuela, M. C., Monteagudo, A., Vásquez, R., Prieto, A., Rudas, A., Almeida, S., Higuchi, N., Lezama, A. T., López-González, G., Peacock, J., Fyllas, N. M., Alvarez Dávila, E., Erwin, T., di Fiore, A., Chao, K. J., Honorio, E., Killeen, T., Peña Cruz, A., Pitman, N., Núñez Vargas, P., Salomão, R., Terborgh, J., and Ramírez, H.: Regional and large-scale patterns in Amazon forest structure and function are mediated by variations in soil physical and chemical properties, Biogeosciences Discuss., 6, 39934057, doi:10.5194/bgd-6-3993-2009, 2009.

Quesada, C. A., Lloyd, J., Schwarz, M., Patiño, S., Baker, T. R., Czimczik, C., Fyllas, N. M., Martinelli, L., Nardoto, G. B., Schmerler, J., Santos, A. J. B., Hodnett, M. G., Herrera, R., Luizão, F. J., Arneth, A., Lloyd, G., Dezzeo, N., Hilke, I., Kuhlmann, I., Raessler, M., Brand, W. A., Geilmann, H., Moraes Filho, J. O., Carvalho, F. P., Araujo Filho, R. N., Chaves, J. E., Cruz Junior, O. F., Pimentel, T. P., and Paiva, R.: Variations in chemical and physical properties of Amazon forest soils in relation to their genesis, Biogeosciences, 7, 1515-1541, doi:10.5194/bg-7-15152010, 2010.

Rinne, H. J. I., Guenther, A. B., Greenberg, J. P., and Harley, P. C.: Isoprene and monoterpene fluxes measured above Amazonian rainforest and their dependence on light and temperature, Atmos. Environ., 36, 2421-2426, 2002.

Rissler, J., Swietlicki, E., Zhou, J., Roberts, G., Andreae, M. O., Gatti, L. V., and Artaxo, P.: Physical properties of the sub-micrometer aerosol over the Amazon rain forest during the wet-to-dry season transition - comparison of modeled and measured CCN concentrations, Atmos. Chem. Phys., 4, 2119-2143, doi:10.5194/acp-4-2119-2004, 2004.

Roberts, G. C., Andreae, M. O., Maenhaut, W., and FernandezJimenez, M. T.: Composition and sources of aerosol in a cen- tral African rain forest during the dry season, J. Geophys. Res.Atmos., 106(D13), 14423-14434, 2001a.

Roberts, G. C., Artaxo, P., Zhou, J. C., Swietlicki, E., and Andreae, M. O.: Sensitivity of CCN spectra on chemical and physical properties of aerosol: A case study from the Amazon Basin, J. Geophys. Res.-Atmos., 107(D20), 8070, doi:10.1029/2001JD000583, 2002.

Roberts, G. C., Nenes, A., Seinfeld, J. H., and Andreae, M. O.: Impact of biomass burning on cloud properties in the Amazon Basin, J. Geophys. Res.-Atmos., 108(D2), 4062, doi:10.1029/2001JD000985, 2003.

Roberts, J. M., Williams, J., Baumann, K., Buhr, M. P., Goldan, P. D., Holloway, J., Hubler, G., Kuster, W. C., McKeen, S. A., Ryerson, T. B., Trainer, M., Williams, E. J., Fehsenfeld, F. C., Bertman, S. B., Nouaime, G., Seaver, C., Grodzinsky, G., Rodgers, M., and Young, V. L.: Measurements of PAN, PPN, and MPAN made during the 1994 and 1995 Nashville Intensives of the Southern Oxidant Study: Implications for regional ozone production from biogenic hydrocarbons, J. Geophys. Res.-Atmos., 103(D17), 22473-22490, 1998.

Roberts, M. C., Andreae, M. O., Zhou, J. C., and Artaxo, P.: Cloud condensation nuclei in the Amazon Basin: "Marine" conditions over a continent?, Geophys. Res. Lett., 28, 2807-2810, 2001b.

Roelofs, G.-J. and Lelieveld J.: Model study of the influence of cross-tropopause $\mathrm{O}_{3}$ transports on tropospheric $\mathrm{O}_{3}$ levels, Tellus, 49B, 38-55, 1997.

Rosenfeld, D., Lahav, R., Khain, A., and Pinsky, M.: The role of sea spray in cleansing air pollution over ocean via cloud processes, Science, 297, 1667-1670, 2002.

Rosenfeld, D., Lohmann, U., Raga, G. B., O’Dowd, C. D., Kulmala, M., Fuzzi, S., Reissell, A., and Andreae, M. O.: Flood or drought: How do aerosols affect precipitation?, Science, 321, 1309-1313, 2008.

Rummel, U., Ammann, C., Gut, A., Meixner, F. X., and Andreae, M. O.: Eddy covariance measurements of nitric oxide flux within an Amazonian rain forest, J. Geophys. Res.-Atmos., 107(D20), 8050, doi:10.1029/2001JD000520, 2002.

Ryerson, T. B., Buhr, M. P., Frost, G. J., Goldan, P. D., Holloway, J. S., Hubler, G., Jobson, B. T., Kuster, W. C., McKeen, S. A., Parrish, D. D., Roberts, J. M., Sueper, D. T., Trainer, M., Williams, J., and Fehsenfeld, F. C.: Emissions lifetimes and ozone formation in power plant plumes, J. Geophys. Res.-Atmos., 103(D17), 22569-22583, 1998.

Ryerson, T. B., Trainer, M., Holloway, J. S., Parrish, D. D., Huey, L. G., Sueper, D. T., Frost, G. J., Donnelly, S. G., Schauffler, S., Atlas, E. L., Kuster, W. C., Goldan, P. D., Hubler, G., Meagher, J. F., and Fehsenfeld, F. C.: Observations of ozone formation in power plant plumes and implications for ozone control strategies, Science, 292, 719-723, 2001.

Ryerson, T. B., Trainer, M., Angevine, W. M., Brock, C. A., Dissly, R. W., Fehsenfeld, F. C., Frost, G. J., Goldan, P. D., Holloway, J. S., Hubler, G., Jakoubek, R. O., Kuster, W. C., Neuman, J. A., Nicks, D. K., Parrish, D. D., Roberts, J. M., and Sueper, D. T.: Effect of petrochemical industrial emissions of reactive alkenes and $\mathrm{NO}_{\mathrm{x}}$ on tropospheric ozone formation in Houston, Texas, J. Geophys. Res.-Atmos., 108(D8), 4249, doi:10.1029/2002JD003070, 2003.

Sachse, G. W., Harriss, R. C., Fishman, J., Hill, G. F., and Cahoon, D. R.: Carbon-monoxide over the Amazon Basin during the 1985 
dry season, J. Geophys. Res.-Atmos., 93(D2), 1422-1430, 1988.

Schwarz, J. P., Gao, R. S., Spackman, J. R., Watts, L. A., Thomson, D. S., Fahey, D. W., Ryerson, T. B., Peischl, J., Holloway, J. S., Trainer, M., Frost, G. J., Baynard, T., Lack, D. A., de Gouw, J. A., Warneke, C., and Del Negro, L. A.: Measurement of the mixing state, mass, and optical size of individual black carbon particles in urban and biomass burning emissions, Geophys. Res. Lett., 35, L13810, doi:10.1029/2008GL033968, 2008.

Sillman, S.: The relation between ozone, $\mathrm{NO}_{\mathrm{x}}$ and hydrocarbons in urban and polluted rural environments, Atmos. Environ., 33, 1821-1845, 1999.

Singh, H. B., Herlth, D., Ohara, D., Salas, L., Torres, A. L., Gregory, G. L., Sachse, G. W., and Kasting, J. F.: Atmospheric peroxyacetyl nitrate measurements over the Brazilian Amazon Basin during the wet season - relationships with nitrogen-oxides and ozone, J. Geophys. Res.-Atmos., 95(D12), 16945-16954, 1990.

Sitch, S., Cox, P. M., Collins, W. J., and Huntingford, C.: Indirect radiative forcing of climate change through ozone effects on the land-carbon sink, Nature, 448, 791-794, 2007.

Song, C., Na, K. S., and Cocker, D. R.: Impact of the hydrocarbon to $\mathrm{NO}_{\mathrm{x}}$ ratio on secondary organic aerosol formation, Environ. Sci. Technol., 39, 3143-3149, 2005.

Spirig, C., Neftel, A., Kleinman, L. I., and Hjorth, J.: $\mathrm{NO}_{\mathrm{x}}$ versus VOC limitation of $\mathrm{O}_{3}$ production in the Po valley: Local and integrated view based on observations, J. Geophys. Res.-Atmos., 107(D22), 8191, doi:10.1029/2001JD000561, 2002.

Starn, T. K., Shepson, P. B., Bertman, S. B., White, J. S., Splawn, B. G., Riemer, D. D., Zika, R. G., and Olszyna, K.: Observations of isoprene chemistry and its role in ozone production at a semirural site during the 1995 Southern Oxidants Study, J. Geophys. Res.Atmos., 103(D17), 22425-22435, 1998.

Surratt, J. D., Murphy, S. M., Kroll, J. H., Ng, N. L., Hildebrandt, L., Sorooshian, A., Szmigielski, R., Vermeylen, R., Maenhaut, W., Claeys, M., Flagan, R. C., and Seinfeld, J. H.: Chemical composition of secondary organic aerosol formed from the photooxidation of isoprene, J. Phys. Chem. A, 110, 9665-9690, 2006.

Thompson, A. M.: The oxidizing capacity of the Earth's atmosphere: Probable past and future changes, Science, 256, 11571165, 1992.

Torres, A. L. and Buchan, H.: Tropospheric nitric-oxide measurements over the Amazon Basin, J. Geophys. Res.-Atmos., 93(D2), 1396-1406, 1988.

Trainer, M., Williams, E. J., Parrish, D. D., Buhr, M. P., Allwine, E. J., Westberg, H. H., Fehsenfeld, F. C., and Liu, S. C.: Models and observations of the impact of natural hydrocarbons on rural ozone, Nature, 329, 705-707, 1987.

Trainer, M., Ridley, B. A., Buhr, M. P., Kok, G., Walega, J., Hubler, G., Parrish, D. D., and Fehsenfeld, F. C.: Regional ozone and urban plumes in the Southeastern United-States - Birmingham, a case-study, J. Geophys. Res.-Atmos., 100(D9), 18823-18834, 1995.

Trainer, M., Parrish, D. D., Goldan, P. D., Roberts, J., and Fehsenfeld, F. C.: Review of observation-based analysis of the regional factors influencing ozone concentrations, Atmos. Environ., 34, 2045-2061, 2000.

Trentmann, J., Yokelson, R. J., Hobbs, P. V., Winterrath, T., Christian, T. J., Andreae, M. O., and Mason, S. A.: An analysis of the chemical processes in the smoke plume from a savanna fire, J. Geophys. Res.-Atmos., 110(D12), D12301, doi:10.1029/2004JD005628, 2005.

Tsigaridis, K. and Kanakidou, M.: Global modelling of secondary organic aerosol in the troposphere: a sensitivity analysis, Atmos. Chem. Phys., 3, 1849-1869, doi:10.5194/acp-3-1849-2003, 2003.

Tuazon, E. C. and Atkinson, R.: A product study of the gas-phase reaction of isoprene with the $\mathrm{OH}$ radical in the presence of $\mathrm{NO}_{\mathrm{x}}$, Int. J. Chem. Kinet., 22, 1221-1236, 1990.

Vestin, A., Rissler, J., Swietlicki, E., Frank, G. P., and Andreae, M. O.: Cloud-nucleating properties of the Amazonian biomass burning aerosol: Cloud condensation nuclei measurements and modeling, J. Geophys. Res.-Atmos., 112(D14), D14201, doi:10.1029/2006JD8104, 2007.

Vitousek, P. M.: Litterfall, nutrient cycling, and nutrient limitation in tropical forests, Ecology, 65, 285-298, 1984.

Volkamer, R., Jimenez, J. L., San Martini, F., Dzepina, K., Zhang, Q., Salcedo, D., Molina, L. T., Worsnop, D. R., and Molina, M. J.: Secondary organic aerosol formation from anthropogenic air pollution: Rapid and higher than expected, Geophys. Res. Lett., 33, L17811, doi:10.1029/2006GL026899, 2006.

Warneke, C., Holzinger, R., Hansel, A., Jordan, A., Lindinger, W., Poschl, U., Williams, J., Hoor, P., Fischer, H., Crutzen, P. J., Scheeren, H. A., and Lelieveld, J.: Isoprene and its oxidation products methyl vinyl ketone, methacrolein, and isoprene related peroxides measured online over the tropical rain forest of Surinam in March 1998, J. Atmos. Chem., 38, 167-185, 2001.

Wehner, B., Birmili, W., Ditas, F., Wu, Z., Hu, M., Liu, X., Mao, J., Sugimoto, N., and Wiedensohler, A.: Relationships between submicrometer particulate air pollution and air mass history in Beijing, China, 2004-2006, Atmos. Chem. Phys., 8, 6155-6168, doi:10.5194/acp-8-6155-2008, 2008.

Wiedinmyer, C., Friedfeld, S., Baugh, W., Greenberg, J., Guenther, A., Fraser, M., and Allen, D.: Measurement and analysis of atmospheric concentrations of isoprene and its reaction products in central Texas, Atmos. Environ., 35, 1001-1013, 2001.

Williams, E., Rosenfeld, D., Madden, N., Gerlach, J., Gears, N., Atkinson, L., Dunnemann, N., Frostrom, G., Antonio, M., Biazon, B., Camargo, R., Franca, H., Gomes, A., Lima, M., Machado, R., Manhaes, S., Nachtigall, L., Piva, H., Quintiliano, W., Machado, L., Artaxo, P., Roberts, G., Renno, N., Blakeslee, R., Bailey, J., Boccippio, D., Betts, A., Wolff, D., Roy, B., Halverson, J., Rickenbach, T., Fuentes, J., and Avelino, E.: Contrasting convective regimes over the Amazon: Implications for cloud electrification, J. Geophys. Res.-Atmos., 107(D20), 8082 doi:10.1029/2001JD000380, 2002.

Yokelson, R. J., Bertschi, I. T., Christian, T. J., Hobbs, P. V., Ward, D. E., and Hao, W. M.: Trace gas measurements in nascent, aged, and cloud-processed smoke from African savanna fires by airborne Fourier transform infrared spectroscopy (AFTIR), J. Geophys. Res.-Atmos., 108(D13), 8478, doi:10.1029/2002JD002322, 2003.

Zhang, Q., Stanier, C. O., Canagaratna, M. R., Jayne, J. T., Worsnop, D. R., Pandis, S. N., and Jimenez, J. L.: Insights into the chemistry of new particle formation and growth events in Pittsburgh based on aerosol mass spectrometry, Environ. Sci. Technol., 38, 4797-4809, 2004. 